INTER NATIONAL MONETARY FUND
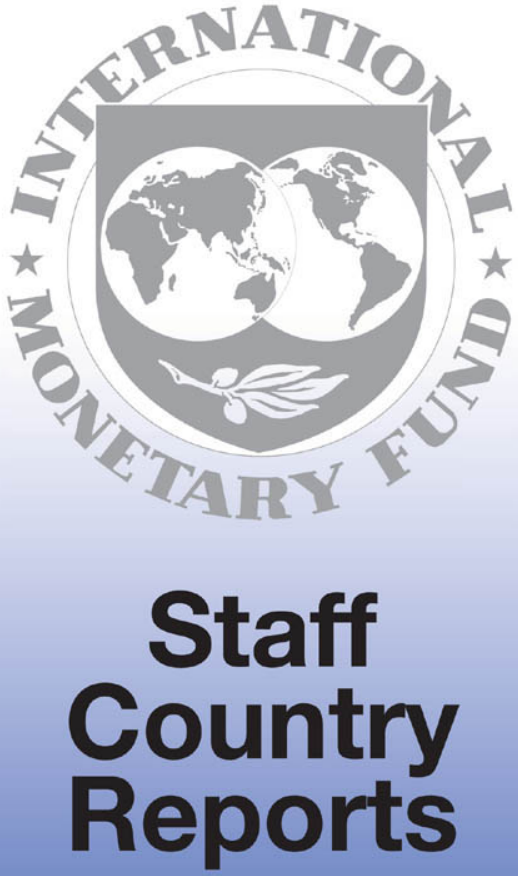


\section{Burundi-Enhanced Heavily Indebted Poor Countries Initiative- Completion Point Document and Multilateral Debt Relief Initiative}

This paper was prepared by staffs of the International Monetary Fund and the World Bank in connection with the Executive Board's consideration of Burundi's completion point under the enhanced Initiative for Heavily Indebted Poor Countries and debt relief under the Multilateral Debt Relief Initiative. It is based on the information available at the time it was completed on January 6, 2009. The views expressed in this document are those of the staff team and do not necessarily reflect the views of the government of Burundi or the Executive Board of the IMF.

The policy of publication of staff reports and other documents by the IMF allows for the deletion of market-sensitive information.

Copies of this report are available to the public from

International Monetary Fund • Publication Services

700 19th Street, N.W. • Washington, D.C. 20431

Telephone: (202) 623-7430 • Telefax: (202) 623-7201

E-mail: publications@imf.org •Internet: http://www.imf.org

\section{International Monetary Fund Washington, D.C.}


This page intentionally left blank 


\section{INTERNATIONAL DEVELOPMENT ASSOCIATION AND THE INTERNATIONAL MONETARY FUND}

\section{BURUNDI \\ Enhanced Heavily Indebted Poor Countries (HIPC) Initiative Completion Point Document and Multilateral Debt Relief Initiative (MDRI) \\ Prepared by the Staffs of the International Monetary Fund and the International Development Association \\ Approved by Obiageli K. Ezekwesili and Danny Leipziger (IDA) Robert Sharer and Dominique Desruelle (IMF)}

$$
\text { January 6, } 2009
$$

Contents

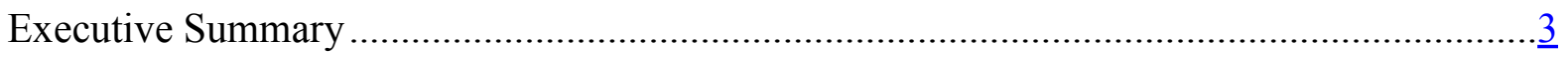

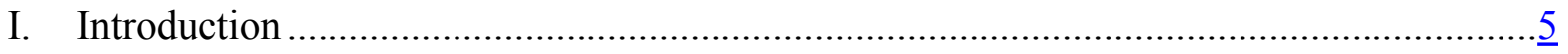

II. Assessment of Requirements for Reaching the Completion Point .................................
A. PRSP and Poverty Monitoring

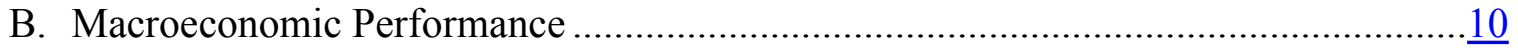
C. Use of Interim Debt Relief.......................................................................... $\frac{11}{13}$
D. Public Expenditure Management .......................................................................... $\frac{13}{13}$
E. Governance Measures and the Delivery of Services in Key Sectors........................14

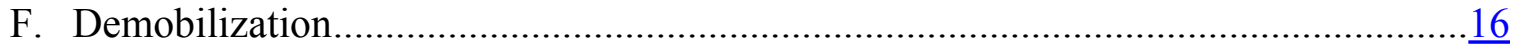
G. Structural Measures ….............................................................................. $\frac{18}{20}$
H. Social Sector Reforms...............................................................................
I. Debt Management ....................................................................................... $\frac{23}{2}$

III. Debt Relief and Debt Sustainability Analysis .......................................................23
A. Updated Data Reconciliation and Revision of Assistance .....................................
B. Status of Creditor Participation in the Enhanced HIPC Initiative ............................ $\frac{25}{26}$
C. Consideration for Exceptional Topping Up of HIPC Assistance ............................. $\frac{26}{26}$
D. Creditor Participation in the Multilateral Debt Relief Initiative .................................29

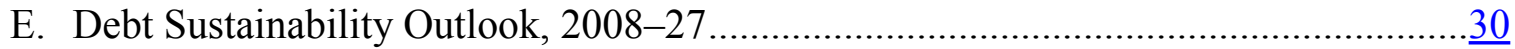
F. Sensitivity Analysis and Long-Term Debt Sustainability .....................................

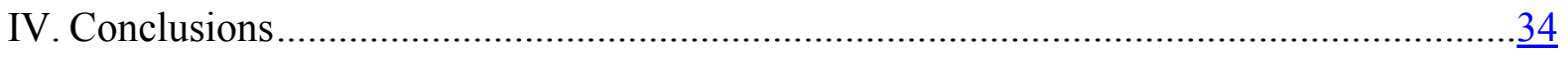

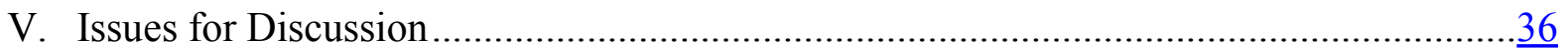


Figures

1. Composition of the Stock of External Debt by Creditor Group....................................

2. External Debt and Debt Service Indicators .......................................................... $\frac{38}{39}$

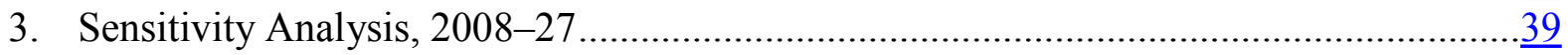

Tables

1. Selected Macroeconomic Indicators, 2001-08 ….................................................11

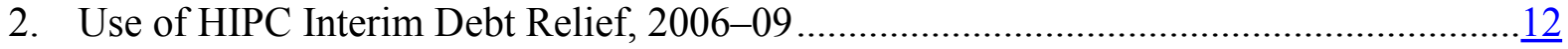

3. Progress Under the National Program for Demobilization, Reinsertion and Reintegration .17

4. Gross School Enrollment Rates, 2001/02-2006/07 ..................................................... $\frac{21}{28}$

5. Breakdown of the Increase in the NPV of Debt-to-Exports Ratio at end-2007 ...............28

6. Revised Nominal Stock and Net Present Value of Debt at the Decision Point by Creditor Groups at end-December, 2004 .$\underline{40}$

7. Estimated Assistance at the Decision Point (Amended) .............................................. 41

8. Comparison of Discount Rate and Exchange Rate Assumptions ................................. 42

9. Status of Creditor Participation Under the Enhanced HIPC Initiative ............................. 43

10. Nominal and Net Present Value of External Debt Outstanding

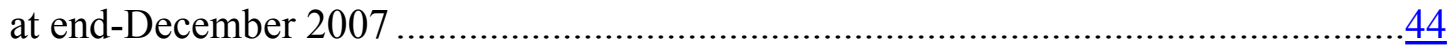

11. Net Present Value of External Debt .......................................................................... 45

12. External Debt Service After Full Implementation of Debt-Relief Mechanisms.............. $\underline{46}$

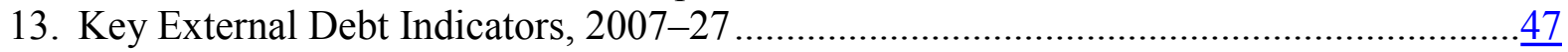

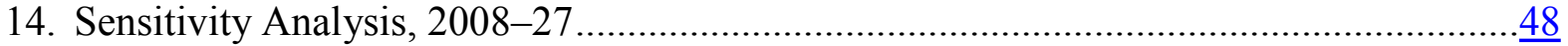

15. Delivery of IMF Assistance Under the Enhanced HIPC Initiative and MDRI, 2005-15 ............................................................................. 49

16. Delivery of World Bank HIPC Assistance and MDRI, 2005-45 .................................

17. Paris Club Creditors' Delivery of Debt Relief Under Bilateral Initiatives

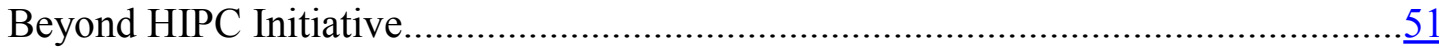

18. HIPC Initiative: Status of Country Cases Considered Under the Initiative ......................52

19. Selected Economic and Financial Indicators, 2003-27 ..........................................

Boxes

1. Status of Floating Completion Point Triggers ….........................................................

2. Reforms in Public Financial Management ................................................................ 14

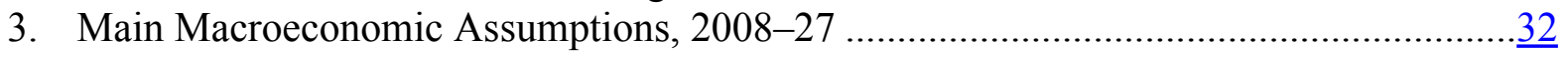

Appendices

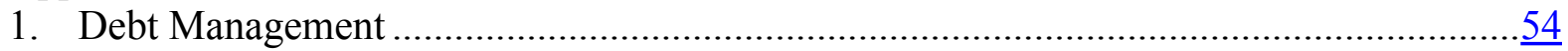

2. Debt Sustainability Analysis Using the Low-Income Country Framework ...................... $\underline{55}$ 


\section{EXECUTIVE SUMMARY}

- In August 2005 the Boards of Executive Directors of IDA and the IMF agreed that Burundi had met the requirements for reaching the decision point under the enhanced HIPC Initiative. The amount of debt relief committed at the decision point was US\$826 million in NPV terms (US\$1,495 million of debt relief in nominal terms over time), calculated to reduce the NPV of debt to 150 percent of exports at end-2004. This relief represents a common reduction factor of 91.5 percent for all creditors.

- In the view of the IDA and IMF staffs, Burundi has made satisfactory progress in meeting the requirements for reaching the completion point. The first full PRSP was presented to the World Bank and IMF Boards in March 2007. Implementation has been satisfactory, as acknowledged by the Joint Staff Advisory Note (JSAN) and the first Annual Progress Report (APR) of the PRSP. The first review under the new PRGF arrangement will be presented to the IMF Board together with the completion point document and the APR/JSAN before the World Bank Board meeting. The IMF staff will recommend completion of the first review of the PRGF arrangement given the satisfactory implementation of the program in 2008. The implementation of other triggers has been substantially satisfactory. In all, the authorities have implemented six out of nine triggers and are requesting waivers for the remaining three, based on the good progress achieved so far.

- Satisfactory progress has been made with the three triggers not fully implemented. These are the triggers on demobilization, the coffee sector and the social sectors. The demobilization, reinsertion and reintegration program has substantially met the majority of its goals, with the final size of the army and police reasonably close to the respective targets of 25,000 and 15,000. A power-sharing agreement was signed with the last rebel group only in December 2008. Regarding the tendering for sale of the state holdings in a majority of coffee washing stations, the government is implementing an action plan for the overall reform of the sector (not envisaged by the completion point trigger) that addresses divestiture as well as regulatory and institutional aspects of the sector. As a result, the government's decision on a divestiture option for the government-owned washing stations was taken late in the process. The proposed course of action is more likely to be successfully implemented as it has been accepted by all major stakeholders. Regarding the trigger on social sectors, the staffs recognize the government's strong commitment to improving health services and vaccination coverage in particular, but note the general weaknesses of the health system in a country with continued internal conflict. The government is implementing corrective measures.

- The debt reconciliation exercise undertaken ahead of the completion point leads to an upward revision of the end-2004 NPV of debt after traditional debt relief from US\$902.0 million to US\$908.8 million. This revision would imply an increase in the HIPC debt relief in NPV terms from the decision point estimate of US\$825.7 million to 
US\$832.6 million. The implied common reduction factor at the decision point would increase from 91.54 to 91.62 percent.

- Creditors accounting for 96 percent of total HIPC assistance in NPV terms have given satisfactory assurances of their participation in the enhanced HIPC Initiative. All Paris Club creditors and most multilateral creditors have confirmed their participation. The authorities are working toward reaching agreements with all remaining creditors.

- The IDA and IMF staffs observed a slight deterioration in debt burden indicators at end-2007, compared with the projection made at the time of the decision point. The updated analysis based on end-2007 data indicates that the NPV of debt-to-exports ratio at end-2007, after full delivery of HIPC debt relief, stood at 195.7 percent, compared with 180.4 percent projected at the decision point. Taking into account debt relief beyond HIPC provided by Paris Club creditors on a voluntary basis, the NPV of debt-to-exports ratio at end-2007 is estimated at 190.3 percent.

- The staffs are of the view that Burundi does not meet the requirements for exceptional topping-up under the enhanced HIPC Initiative. The staffs consider that the deterioration in the NPV of debt-to-exports ratio, after taking into account additional debt relief is fairly modest, and therefore not primarily attributable to a fundamental change in Burundi's economic circumstances due to exogenous factors. In addition, the most important factor contributing to the increase (higher than expected new borrowing) is not considered to be in response to an exogenous shock.

- Upon reaching the completion point under the enhanced HIPC Initiative, Burundi will also qualify for additional debt relief under the Multilateral Debt Relief Initiative (MDRI). Debt relief under the MDRI would cover all remaining debt service obligations on eligible credit balances to IDA, the African Development Fund (AfDF) and the IMF. MDRI relief net of HIPC assistance would lead to a nominal reduction of debt owed to IDA, the IMF and the AfDF of respectively US\$90.4 million, SDR9.2 million (US\$14.5 million) and US\$12.6 million.

- $\quad$ Full delivery of HIPC and MDRI debt relief at the completion point would significantly reduce Burundi's external public debt. However, Burundi's external public debt burden indicators are expected to remain high over the medium term. After HIPC and MDRI assistance, the NPV of debt-to-exports ratio is expected to decline from 967 percent at end-2007 to 148 percent at end-2009. It would subsequently rise to 169 percent by end2011 , before continuing on a slow downward trend, reaching 75 percent by the end of the projection period.

- The staffs recommend that the Executive Directors of IDA and the IMF approve the completion point for Burundi under the enhanced HIPC Initiative. 


\section{INTRODUCTION}

1. This paper discusses the progress made by Burundi under the enhanced Heavily Indebted Poor Countries (HIPC) Initiative. It recommends that the Executive Directors of the International Development Association (IDA) and the International Monetary Fund (IMF) approve the completion point for Burundi under the enhanced HIPC Initiative. In the view of the staffs, Burundi has made satisfactory progress in achieving the completion point triggers. In particular, it has fully implemented the triggers on preparing and implementing a Poverty Reduction Strategy Paper (PRSP), maintaining a stable macroeconomic environment, setting up mechanisms to ensure efficient and transparent use of HIPC interim debt relief, implementing public expenditure and other governance measures to improve the allocative and administrative efficiency of public funds, and strengthening debt management through the preparation of monthly external debt reports. Three of the nine triggers have not been fully implemented, namely the triggers on the national disarmament, demobilization and reintegration policy, the coffee sector, and the social sectors. The authorities are requesting waivers for the three triggers not fully implemented on the basis of the good progress achieved so far.

\section{In August 2005, the Boards of Executive Directors of IDA and the IMF agreed} that Burundi had met the requirements for reaching the decision point under the enhanced HIPC Initiative. ${ }^{1}$ Directors welcomed the progress made by Burundi in strengthening macroeconomic policy performance and deepening the structural reform agenda. They noted the important steps taken by the authorities to solidify peace and bring the political transition process to a successful conclusion. In view of Burundi's high debt burden, Executive Directors agreed that a total of US\$826 million of debt relief in NPV terms (US\$1,495 million of debt relief in nominal terms) would be required to reduce the NPV of debt to 150 percent of exports at end-2004. This relief represented a common reduction factor of 91.5 percent for all creditors. At the same time, interim debt relief was granted by the Boards of IDA and the IMF until the country reached its floating completion point. Interim assistance under the enhanced HIPC Initiative was also granted by the African Development Bank (AfDB) Group, the European Union (EU), the Paris Club, and other multilateral creditors. Executive Directors determined that the completion point would be reached when Burundi complied with the triggers set out in Box 6 of the decision point document and satisfactory assurances of other creditors' participation in the enhanced HIPC Initiative were received.

3. This document is organized as follows: Section II assesses Burundi's performance in meeting the requirements for reaching the completion point under the enhanced HIPC Initiative. Section III provides an updated debt relief and debt sustainability analysis (DSA), including the status of creditor participation, delivery of debt relief under the enhanced HIPC and MDRI Initiatives, and consideration of a topping-up of assistance under the enhanced

\footnotetext{
${ }^{1}$ See Burundi: Decision Point Document for the Enhanced Initiative for Heavily Indebted Poor Countries, (IDA/R2005-0174 and IMF Country Report No. 05/329), September 3, 2005.
} 
HIPC Initiative. Section IV summarizes the main conclusions, and Section V presents issues for discussion by the Boards of IDA and the IMF.

\section{Assessment of ReQuirements for Reaching the Completion Point}

\section{Burundi has made solid progress in meeting the triggers for reaching the}

completion point. The conditions for reaching the floating completion point triggers, set out in Box 6 of the decision point document (and below in Box 1), relate to:

(i) preparation of a full PRSP and satisfactory implementation for one year, as evidenced by a Joint Staff Advisory Note (JSAN) and an Annual Progress Report;

(ii) maintenance of macroeconomic stability as evidenced by satisfactory performance under the PRGF-supported program;

(iii) use of budget savings resulting from HIPC interim funds in accordance to priorities identified at the decision point and in the PRSP;

(iv) strengthening of public expenditure management;

(v) implementation of governance measures related to social sector services delivery;

(vi) satisfactory progress in execution of the demobilization program;

(vii) tendering for sale the state holdings in a majority of washing stations;

(viii) satisfactory progress in achieving education and health goals; and

(ix) improved debt management capacity.

This section assesses performance relative to these triggers. 


\begin{tabular}{|c|c|}
\hline \multicolumn{2}{|c|}{ Box 1. Status of Floating Completion Point Triggers } \\
\hline Triggers & Progress \\
\hline $\begin{array}{l}\text { 1. PRSP: Preparation of a full PRSP through a participatory process } \\
\text { and its satisfactory implementation for one year, as evidenced by an } \\
\text { Annual Progress Report that has been the subject of analysis in a } \\
\text { Joint Staff Advisory Note. }\end{array}$ & $\begin{array}{l}\text { Implemented. A full PRSP drafted in a participatory process was } \\
\text { published in September } 2006 \text { and discussed by the IMF and IDA } \\
\text { Boards in March } 2007 \text {. The Annual Progress Report was prepared } \\
\text { in a participatory process by the monitoring PRSP permanent } \\
\text { secretariat and officially sent to the IMF and IDA in November } \\
\text { 2008. The JSAN of the APR is being presented to IDA and the IMF } \\
\text { Boards together with this document. }\end{array}$ \\
\hline $\begin{array}{l}\text { 2. Macroeconomic stability: Maintenance of macroeconomic } \\
\text { stability as evidenced by satisfactory performance under the PRGF- } \\
\text { supported program. }\end{array}$ & $\begin{array}{l}\text { Implemented. Macroeconomic developments since the decision } \\
\text { point have been broadly satisfactory. The PRGF-supported program } \\
\text { remained on track except briefly in mid-2007. Performance under } \\
\text { the new PRGF arrangement approved in July } 2008 \text { is broadly } \\
\text { satisfactory. IMF staff will recommend that the first review under } \\
\text { the PRGF arrangement be completed together with the discussion of } \\
\text { the HIPC completion point. }\end{array}$ \\
\hline $\begin{array}{l}\text { 3. Use of budget savings resulting from HIPC-related debt- } \\
\text { service relief during the interim period: Use of budgetary savings } \\
\text { from debt relief in accordance with the priorities identified at the } \\
\text { decision point and in the PRSP duly documented and discussed by a } \\
\text { national Independent Oversight Committee on a semi-annual basis. }\end{array}$ & $\begin{array}{l}\text { Implemented. Budgetary allocations for priority spending targeting } \\
\text { pro-poor activities and projects have increased markedly, reflecting } \\
\text { PRSP priority areas. Since } 2006 \text { more than half of HIPC resources } \\
\text { have been allocated to key social sectors (education, public health } \\
\text { and fight against AIDS). The HIPC Independent Oversight } \\
\text { Committee was reactivated in mid-2007 and now meets regularly to } \\
\text { review HIPC-related allocations and spending. Two audits of the } \\
\text { HIPC program were undertaken in May and August } 2008 \text {. In } \\
\text { November } 2008 \text {, he Committee adopted a set of measures to address } \\
\text { comments raised by the audits. }\end{array}$ \\
\hline $\begin{array}{l}\text { 4. Public expenditure management: Establishment of an } \\
\text { integrated public expenditure computerized system that provides a } \\
\text { budget monitoring and control system, in particular for poverty- } \\
\text { related spending, and the production of at least two quarterly budget } \\
\text { execution reports based on the new unified budget nomenclature. }\end{array}$ & $\begin{array}{l}\text { Implemented. An integrated computerized expenditure } \\
\text { management system (SIGEFI) was put in place in January } \\
2006 \text { using a new budgetary nomenclature that includes economic, } \\
\text { functional, and administrative classifications and identifies the } \\
\text { poverty-related spending clearly. Quarterly budget execution reports } \\
\text { have been produced since mid-2006. }\end{array}$ \\
\hline $\begin{array}{l}\text { 5. Governance measures and the delivery of services in key } \\
\text { sectors: Completion for the education, health, and justice sectors of } \\
\text { (i) a budget tracking exercise (budget monitoring) of public } \\
\text { spending on the delivery of pro-poor services; (ii) an evaluation by } \\
\text { users of the quality of services provided; (iii) an evaluation by } \\
\text { providers of constraints to effective delivery of pro-poor services; } \\
\text { and (iv) preparation of an action plan to address problems } \\
\text { identified. }\end{array}$ & $\begin{array}{l}\text { Implemented. The surveys were completed by December } 2007 \text {, the } \\
\text { related analysis was completed and an action plan to address the } \\
\text { findings was adopted in December } 2008 \text {. }\end{array}$ \\
\hline $\begin{array}{l}\text { 6. Demobilization: Execution of the National DDR Program in line } \\
\text { with the pace and final objectives set forth in the Letter of } \\
\text { Demobilization Policy to the World Bank, dated } 19 \text { February, } 2004 .\end{array}$ & $\begin{array}{l}\text { Substantially Implemented. The National Demobilization, } \\
\text { Reinsertion and Reintegration Program (PNDRR) has substantially } \\
\text { met the majority of its objectives. All } 23,022 \text { adult personnel } \\
\text { discharged by the Ministries of Defense and Interior as part of the } \\
\text { PNDRR were demobilized and received a full course of reinsertion } \\
\text { allowances. Of these personnel, } 22,024 \text { received socio-economic } \\
\text { reintegration support. A total of } 3,261 \text { children were released from } \\
\text { armed groups, of which } 3,015 \text { received a reinsertion allowance. The } \\
\text { Gardiens de la paix and Militants combatants were disbanded and } \\
28,379 \text { individuals received reinsertion allowances. The final size } \\
\text { of the army and police has been assessed at } 26,588 \text { active duty army } \\
\text { personnel and } 17,161 \text { police members - compared to the respective } \\
\text { targets of } 25,000 \text { and } 15,000 \text {. An official census exercise is on- } \\
\text { going. Full compliance with the trigger was not possible mainly } \\
\text { because a ceasefire agreement with the last remaining rebel group, } \\
\text { the FNL, was signed late in the process and a power-sharing } \\
\text { agreement was reached only in December } 2008 \text {. }\end{array}$ \\
\hline
\end{tabular}




\begin{tabular}{|c|c|}
\hline Triggers & Progress \\
\hline $\begin{array}{l}\text { 7. Structural measures: Tendering for sale the state holdings in } \\
\text { a majority of coffee washing stations. }\end{array}$ & $\begin{array}{l}\text { Substantially implemented. In November } 2006 \text { the government } \\
\text { approved a detailed action plan for the overall reform of the coffee } \\
\text { sector, prepared with the support of IDA (not envisaged by the } \\
\text { completion point trigger). The action plan included several } \\
\text { measures, including: (i) preparation of a study on the } \\
\text { competitiveness of the sector (done in 2007); (ii) liberalization of } \\
\text { the marketing of coffee (done in May 2008); and (iii) adoption of a } \\
\text { divestiture option for government-owned washing stations and the } \\
\text { drill mill company SODECO. The last measure was done in } \\
\text { December 2008, with implementation expected in 2009. The change } \\
\text { in ownership structure will be accompanied by a new legal, } \\
\text { regulatory and institutional framework. Full compliance with the } \\
\text { trigger is taking longer because of the more extensive nature of the } \\
\text { reform process chosen by the authorities. The proposed course of } \\
\text { action is more likely to be successfully implemented, given its } \\
\text { endorsement by all major stakeholders. }\end{array}$ \\
\hline 8. Social sectors & $\begin{array}{l}\text { Partially Implemented. Full compliance was not achieved because } \\
\text { the national immunization target was not reached. }\end{array}$ \\
\hline $\begin{array}{l}\text { (i) Education: Increase in the gross national enrollment rate in } \\
\text { primary schools from } 74 \text { percent in } 2003 / 04 \text { to } 77 \text { percent in } \\
2006 \text {; and from } 16 \text { percent in } 2003 / 04 \text { to } 18 \text { percent in } 2006 \text { in } \\
\text { secondary schools, subject to the provision that the average } \\
\text { increase in provinces with lower than average enrollment rates in } \\
2004 \text { must be higher than the increase in the national rate over } \\
\text { the same time period. }\end{array}$ & $\begin{array}{l}\text { The elimination of primary school fees in September } 2005 \text { resulted } \\
\text { in a large increase in first-grade enrollment. Gross primary school } \\
\text { enrollment rose from an estimated } 80 \text { percent in } 2003 / 04 \text { to } \\
114 \text { percent in } 2006 / 07 \text {. Secondary-school enrollment increased } \\
\text { from } 12 \text { percent in } 2003 / 4 \text { (instead of } 16 \text { percent, as noted in the } \\
\text { HIPC decision point document) to } 16 \text { percent in } 2006 / 07 \text {. Most } \\
\text { provinces with lower than average primary school enrollment rates } \\
\text { in } 2004 \text { have experienced higher increases in enrollment rates than } \\
\text { the national rate, according to administrative data. Data for } \\
\text { secondary schools at the provincial level were not available for an } \\
\text { assessment. }\end{array}$ \\
\hline $\begin{array}{l}\text { (ii) Health: Increase in the national immunization rate for } \\
\text { children of less than one year of age from } 75 \text { percent in } 2004 \text { to } \\
85 \text { percent in } 2006 \text {, subject to the provision that the average } \\
\text { increase in provinces with lower-than-average immunization } \\
\text { rates in } 2004 \text { must be higher than the increase in the national rate } \\
\text { over the same time period. }\end{array}$ & $\begin{array}{l}\text { The government has implemented a variety of measures to boost } \\
\text { vaccination coverage but has yet to achieve the targeted national } \\
\text { immunization rate due to the general weaknesses of the health } \\
\text { system in a country with continued internal conflict. Projections for } \\
2008 \text {, based on administrative data provided by the authorities show } \\
\text { that only one out of five immunization rates would reach the } \\
\text { targeted } 85 \text { percent coverage. In particular, the immunization rates } \\
\text { are } 91 \text { percent for BCG, } 81 \text { percent for DTC-HepB-Hib3, } 78 \text { percent } \\
\text { for VAR, } 79 \text { percent for Polio and } 70 \text { percent for VAT. In addition, } \\
\text { administrative data are likely to overestimate actual progress and } \\
\text { are not comparable to the original baseline based on official } \\
\text { UNICEF/WHO data. The latter show no improvement since } 2004 \text {. } \\
\text { To address these shortcomings, the government will in 2009: } \\
\text { (i) include vaccination services in the improved "free-services" } \\
\text { package; and (ii) commit additional resources in the area of } \\
\text { statistics to improve data reliability at the national and provincial } \\
\text { levels. }\end{array}$ \\
\hline $\begin{array}{l}\text { 9. Debt management: Production of monthly external debt reports, } \\
\text { including projections for the upcoming three months, for at least six } \\
\text { months before the completion point. }\end{array}$ & $\begin{array}{l}\text { Implemented. The authorities have produced monthly external debt } \\
\text { reports, including projections for the upcoming three months, for six } \\
\text { months during } 2008 \text {. }\end{array}$ \\
\hline
\end{tabular}

\section{A. PRSP ANd Poverty Monitoring}

5. Burundi adopted its first full PRSP in September 2006. The PRSP was prepared through extensive consultations with a broad range of stakeholders including representatives from all 17 provinces and 146 communes, sectoral representatives, the private sector, groups 
representing the disabled and vulnerable, the Parliament and more than 145 grassroots civil society groups.

6. The PRSP identifies seven principles deemed essential for poverty alleviation:

(i) refocusing the role of the state to promote private-sector-driven development;

(ii) maintenance of peace and security; (iii) capacity building; (iv) renewed economic growth;

(v) stronger community involvement; (vi) affirmation of the central role of women; and

(vii) promotion of a new partnership with donors. The sectoral programs and macroeconomic framework are oriented around four strategic axes: improvement of governance and security; promotion of sustainable and equitable economic growth; development of human capital by improving the quality of social services; and combating HIV/AIDS.

7. The PRSP was discussed by the IDA and IMF Boards in March 2007. As noted in the JSAN, the PRSP contains a number of positive features, including a broad-based participative process, and a clear focus on the rural sector, infrastructure development, social services, and regional integration. At the same time, the JSAN underscored the importance of stepping up reforms in public financial management to enhance transparency and accountability and better track poverty-reducing expenditures. It also called for developing a related action plan setting out priority actions, accompanied by costing, timetable of implementation, and performance indicators.

8. The government is working toward further improvements in the institutional framework for evaluating PRSP implementation. It is in the process of operationalizing a participatory institutional framework involving sectors and communities to supervise and evaluate PRSP implementation. The government is also seeking to enhance community involvement through the hiring of a professional company to coordinate work and promote dialogue. Reliable data on poverty and other social indicators are scarce. Improvements in data quality and coverage have recently been made through the renewed efforts of the national statistical office (ISTEEBU) and the assistance of donors. A 2006 Core Welfare Indicator Survey (CWIS) showed that the national poverty rate stood at 69 percent. A new household survey is planned for 2009.

9. Implementation of the PRSP has been satisfactory. The government's Annual Progress Report (APR) for 2007 and the accompanying JSAN, have been submitted to the IDA and IMF Boards jointly with this document. The APR highlights progress in the areas of macroeconomic, sectoral and social policies and in efforts to consolidate peace. The staffs of IDA and the IMF have reviewed progress on each of the PRSP pillars and concluded that PRSP implementation and monitoring have been satisfactory during 2007. Policies in specific areas underlying the implementation of the PRSP and related to the HIPC completion point triggers are reviewed in the remainder of Section II.

10. The IDA and IMF staffs conclude that the trigger on preparation and satisfactory implementation of the PRSP has been implemented. 


\section{B. Macroeconomic Performance}

11. Since reaching the decision point in August 2005, macroeconomic stability has been broadly maintained (Table 1). Despite continued low-level conflict, the implementation of the PRGF arrangement during 2005-08 was generally satisfactory. Good progress was achieved in most of the monetary and budgetary reforms launched under the PRGF-supported program. In 2007 and the first half of 2008, Burundi was among the economies hit hardest by the surge in global food and oil prices. The authorities responded to these shocks by taking fiscal measures to support the most vulnerable groups and increase food production, while monetary policy sought to accommodate the first-round effects of the shock. Donor support in the form of grants was instrumental in facilitating the government's response to the crisis. The PRGF-supported program approved in July 2008 remains on track.

12. Economic growth accelerated, while inflation pressures mounted during the period covered by the PRGF. Real GDP growth averaged 3.5 percent during 2005-08, compared with 2.5 percent during the preceding four-year period. To a large extent, growth acceleration was driven by the restoration of peace and the easing of economic distortions, which enabled donor flows to resume. The program objective of slowing inflation to 4-5 percent was not achieved mainly because of supply-side factors. As a result, the end2008 inflation climbed to 22 percent, from one percent in 2005. Excluding food and oil, the inflation rate was in the high single digits.

\section{The authorities have generally pursued prudent fiscal and monetary policies} during 2005-08. The overall fiscal balance improved considerably, although it fell short of the program target due to higher social outlays. Revenues remained in the range of 19-20 percent of GDP, a level that is very high compared with other sub-Saharan countries at the same stage of development. Monetary policy sought to stabilize prices while allowing sufficient scope for economic growth. Nevertheless inflation, pushed up by oil and food price shocks remains a concern. Most performance criteria and indicative targets were met. The foreign exchange market was liberalized and the premium between the official and parallel rates is below two percent.

14. The external current account deficit worsened during 2005-08. Driven largely by reconstruction efforts and higher oil prices, the external current account deficit averaged about 10 percent of GDP. Higher coffee prices during 2007-08 boosted coffee exports, which account for about two-thirds of total exports. Partly as a result of a surge in donor disbursements, gross official reserves in months of imports increased during 2005-08.

15. The IDA and IMF staffs conclude that the trigger on the maintenance of macroeconomic stability and satisfactory implementation of the PRGF program has been implemented. 
Table 1. Burundi: Selected Macroeconomic Indicators, 2001-08

\begin{tabular}{|c|c|c|c|c|c|c|}
\hline & $\begin{array}{r}2001-04 \\
\text { Aver } \\
\end{array}$ & $\begin{array}{l}05-08 \\
\end{array}$ & 2005 & 2006 & 2007 & $\begin{array}{l}2008 \\
\text { Proj. }\end{array}$ \\
\hline & \multicolumn{6}{|c|}{ (In percentage change, unless otherwise indicated) } \\
\hline \multicolumn{7}{|l|}{ Economic growth and prices } \\
\hline Real GDP & 2.5 & 3.5 & 0.9 & 5.1 & 3.6 & 4.5 \\
\hline Consumer prices (period average) & 6.7 & 12.1 & 13.5 & 2.7 & 8.3 & 23.7 \\
\hline Units of local currency per U.S. dollar (period average) & 986 & 1,064 & 1,075 & 1,029 & 1,087 & \\
\hline \multirow[t]{2}{*}{ Gross investment (in percent of GDP) } & 8.7 & 16.1 & 10.8 & 16.3 & 17.5 & 19.7 \\
\hline & \multicolumn{6}{|c|}{ (In percent of GDP) } \\
\hline \multicolumn{7}{|l|}{ External sector } \\
\hline Exports of goods and services & 7.8 & 10.0 & 11.5 & 10.1 & 8.6 & 9.8 \\
\hline Imports of goods and services & 26.2 & 46.0 & 40.6 & 48.6 & 48.3 & 46.5 \\
\hline External current account balance, including grants & -5.3 & -10.2 & -1.1 & -14.1 & -14.5 & -11.0 \\
\hline Net official external financing & 10.0 & 23.3 & 29.7 & 20.1 & 20.5 & 23.0 \\
\hline \multicolumn{7}{|l|}{ Government finance } \\
\hline Total revenue and grants & 27.5 & 38.1 & 31.7 & 36.8 & 39.5 & 44.6 \\
\hline Total expenditures & 32.0 & 39.5 & 36.8 & 38.2 & 38.5 & 44.8 \\
\hline Overall fiscal balance & -4.4 & -1.4 & -5.1 & -1.4 & 1.0 & -0.2 \\
\hline
\end{tabular}

Sources: Burundi authorities; and staff estimates and projections.

\section{USE OF INTERIM DEBT RELIEF}

16. The Burundi government is redirecting its budget, including resources from interim debt relief, toward poverty-reducing and social expenditures in line with its PRSP goals. Total social expenditures (health, education, and other social expenditures) rose from 6.8 percent of GDP in 2005 to a projected 8.8 percent in 2008. Poverty-reducing expenditures are estimated to constitute over half of total expenditures in 2007 and 2008. Interim debt relief has been used as an integral part of the overall budget to increase social sector and poverty-reducing expenditures. More than half of HIPC resources are being allocated to key social sectors (education, public health, and fight against AIDS). Other poverty-reducing spending includes agriculture, water, electricity, and public works. Projects financed by HIPC resources are selected, based on PRSP priorities, at the time the budget is prepared. Continued reduction in security expenditures will increase fiscal space and further redirect expenditures to achieve PRSP goals. 
Table 2. Burundi: Use of HIPC Interim Debt Relief, 2006-09

(Fbu billion)

\begin{tabular}{lccccccc}
\hline & \multicolumn{2}{c}{2006} & \multicolumn{2}{c}{2007} & 2008 & 2009 \\
\hline & Budget & $\begin{array}{c}\text { Execution } \\
\text { Rate } \\
\text { (Percent) }\end{array}$ & Budget & $\begin{array}{c}\text { Execution } \\
\text { Rate } \\
\text { (Percent) }\end{array}$ & Budget & $\begin{array}{c}\text { Execution } \\
\text { Rate (As of } \\
\text { Sept., } \\
\text { percent) }\end{array}$ & $\begin{array}{c}\text { Budget - } \\
\text { (Proposed) }\end{array}$ \\
\hline TOTAL & 39.4 & 36.8 & 29.6 & 78.4 & 45.7 & 65.3 & 49.2 \\
Of which: & 18.4 & 40.0 & 9.7 & 99.3 & 10.0 & 62.6 & 8.8 \\
$\quad$ Education & 10.3 & 30.0 & 7.7 & 94.7 & 16.8 & 87.8 & 17.6 \\
$\begin{array}{l}\text { Public health } \\
\text { Fight against AIDS }\end{array}$ & 3.6 & 99.5 & 2.4 & 86.1 & 3.0 & 38.3 & 2.1 \\
\hline
\end{tabular}

Sources: Burundi authorities; and IDA staff estimates.

17. The authorities have taken steps to strengthen the tracking of HIPC-financed spending. In October 2005, they established a special Treasury account at the central bank, where budgetary savings from HIPC relief are deposited. However, difficulties related to cash management have not always allowed regular replenishment of the account. Together with procurement delays, they accounted for the delays in the implementation of HIPC projects, especially in 2006. The government established in late 2006 a National Independent Oversight Committee consisting of government and civil society representatives to ensure the proper use of debt service savings. The committee is chaired by the Minister of Finance and the Minister of Good Governance, and representatives of the donor community participate in its deliberations. The Committee was reactivated in June 2007. A secretariat and a technical committee were set up in October 2007 and July 2008 respectively to support its work. Providing appropriate budget allocations would help improve the functionality of the secretariat and the technical committee.

18. The use of HIPC assistance has been the subject of two independent technical and financial audits in May and August 2008. Following these audits, the Independent Oversight Committee took a series of measures to improve the use of HIPC resources, including adoption of clear project selection criteria, and strengthening the role of sectoral "focal points" to ensure better overall supervision of project implementation. Further strengthening the role of these "focal points" hinges on: (i) ensuring early and comprehensive procurement planning and closer supervision of the procurement process; (ii) closer fiduciary verifications to help track HIPC spending in a more systematic manner; (iii) closer physical supervision; and (iv) quarterly reporting of project implementation and outcomes.

19. The IDA and IMF staffs conclude that this trigger has been implemented in view of the satisfactory use of HIPC resources and the monitoring mechanisms put in place. 


\section{Public Expenditure Management}

20. The government has established an integrated public expenditure computerized system (SIGEFI) to improve public financial management (PFM). SIGEFI is functioning and has improved the monitoring of the flow of resources and the timeliness of fiscal reporting. SIGEFI is based on a new budgetary nomenclature that includes economic, functional, and administrative classifications and identifies poverty-related spending clearly. Quarterly budget execution reports have been produced since mid-2006.

21. Substantive progress has been made in other PFM areas. Starting in 2005, the authorities launched an ambitious set of reforms to modernize budget operations and improve transparency (Box 2), supported by the IMF, IDA, and other donors. While the PFM system still faces challenges, the reforms undertaken over the years have resulted in systemic improvements. To increase transparency and accountability, while making budget execution more efficient, a new budget organic law was promulgated in November 2008. To improve the efficiency and transparency of budget preparation, the government also adopted a new budget preparation timetable and a more open approach to sectoral participation in budget development discussions. Furthermore, treasury functions have been streamlined. The cash management committee has been reformed though it needs to meet regularly with the main line ministries. Among its responsibilities are the preparation and implementation of revolving cash flow plans on a quarterly basis. Finally, a new internal inspection and control unit has recently been created at the Ministry of Finance that will become functional during the 2009 budget year.

22. The objective going forward is to stabilize the existing PFM system. In the near term, the authorities intend to adopt and implement a PFM strategy and action plan. Particular attention will also be given to two ongoing initiatives: (i) the gradual implementation of the new budget organic law, including implementation of a new accounting law and improvement in fiscal reporting; and (ii) consolidation of the single Treasury account and effective cash flow management.

23. In view of the satisfactory implementation of the above reforms, the IDA and IMF staffs conclude that this trigger has been implemented. 


\section{Box 2. Reforms in Public Financial Management}

The legal framework for public finances has been tightened. New procurement and customs codes have been adopted. Both pieces of legislation will increase transparency and accountability while making budget execution more efficient. Moreover, a new budget organic law was promulgated by the President in November 2008.

Debt management capacity has been enhanced. The Ministry of Finance now has the exclusive right to negotiate and sign external loans. A computerized foreign debt management system has been installed that can produce monthly debt reports.

Budget and fiscal reporting systems have been revamped, introducing economic, functional, and administrative classifications. The new system has improved fiscal monitoring and expenditure tracking. Moreover, a double-entry accounting system is being introduced gradually with the presentation of closing balances for the 2006 and 2007 accounts.

Budget control has been improved. Specialized departments have been established to improve control of budget execution, among them: (i) an internal inspection and control unit in the Ministry of Finance; (ii) an Inspectorate General of State department; and (iii) a general accounting office. The National Audit Office completed the audit of the 2006 accounts in 2007, and two independent audits of the use of HIPC funds in 2005-07 were completed in 2008.

Treasury functions have been streamlined. The authorities are moving toward a single treasury account by tightening control over cash flows and minimizing idle cash balances in ministry bank accounts. They have: (i) merged the recurrent budget and capital budget accounts; (ii) eliminated seven HIPC sub-accounts in line ministries; and (iii) closed 90 ministry accounts. A cash flow plan was initiated in late 2007 to improve cash management.

Customs and tax administration has been reinforced. A new customs code was promulgated in 2007 to make customs procedures more efficient. Computerization of customs operations through the roll-out of the ASYCUDA++ system has helped reduce clearance times. To improve tax enforcement and combat tax evasion, a reliable computerized tax identification number system has been introduced.

\section{E. Governance Measures ANd the Delivery of Services In Key SeCtors}

24. The authorities have taken steps to address governance issues related to the delivery of services in key sectors. In this regard, they prepared budget tracking analyses in the education, health, and justice sectors. In addition, they conducted surveys of users and providers of services to assess satisfaction with the overall quality of services rendered, as well as areas for further improvements. The analyses have provided valuable insights into the functioning of each sector. They underscore the centralized nature of the budgetary process and the need for more sectoral involvement in budget development and follow-up. Based on these analyses, the authorities adopted in November 2008 an action plan for each of the key sectors in order to improve the delivery of services. The action plans are in line with the government's sectoral strategies. Further analysis will be undertaken to help address identified weaknesses. 


\section{The surveys suggest varying degrees of satisfaction with the level of services}

provided. In the health sector, the rate of patient satisfaction is 82 percent. While health expenditures have increased sharply in recent years, excessive centralization of expenditures and qualified staff in the capital is a cause for concern. In education, the analysis notes the high priority given to primary education by the authorities. Parents' satisfaction with the quality of education is low at around 18 percent for the whole system. This result is driven primarily by concerns over both the quality of and access to education. Among the key weaknesses identified are the low level of non-salary expenditures and the low priority given to the non-primary educational system. In the justice sector, the analysis notes that 51.4 percent of the respondents consider costs to be excessive and not always transparent. Households are more satisfied with local rather than with national judicial administration. Most court cases cover issues related to land tenure (94 percent) and take an average of more than two years to be completed, with delays of over five years for appeals and administrative courts. While budget allocations to the sector have more than doubled since 2003, working conditions in courts and prisons require further improvements.

\section{The government is committed to addressing broader challenges in judicial}

governance. Among the key priorities are measures to address: (i) delays in court rulings and (commercial) dispute resolution; (ii) lack of technical and human capacity to deliver expedited dispute resolution; and (iii) corruption. The government has adopted new investment and customs codes and is finalizing commercial, enterprise and tax codes. In order to improve commercial dispute resolution, the government is proceeding with the computerization of the information system of commercial courts. It has also established an Arbitration Center and a General Inspectorate of the State and Audit Court, and promulgated a new procurement code that became effective in October 2008. Finally, the authorities have raised the salaries of judges and magistrates in an attempt to combat corruption.

\section{Following two recent financial governance incidents, the government implemented} important corrective measures, but judicial proceedings in both cases have yet to reach a conclusion. The government's determined response to both cases demonstrates its commitment to fighting governance impunities. The first incident involved the inappropriate sale of the presidential plane in 2006. Following the sale, the authorities undertook an external audit to ascertain the circumstances surrounding the sale, and adopted an action plan with corrective measures in September 2007. As part of the action plan, a new law on the sale of public goods was promulgated on July 11, 2008. A Parliamentary commission investigated the case and provided a report to the Parliament in July 2008. Judicial proceedings related to the conduct of the parties allegedly responsible are still pending. The second incident relates to payments of US\$17 million to a petroleum trading company (Interpetrol) during February-May 2007 without following the normal budgetary procedures. The government acted quickly to condemn these acts and take corrective measures. It has accelerated the strengthening of fiscal management and the central bank's internal controls. With World Bank support, it completed and published an 
independent external audit of the cross-debts of the oil sector and the government, and is finalizing repayment agreements with all the companies involved. Legal proceedings were also launched in the Interpetrol incident, but have not progressed further since May 2007, when the former Governor of the central bank was arrested in connection with the case.

28. The government seeks to address weak institutional capacity with assistance from the international community. The IMF, the EU, the Netherlands, the United Kingdom, Belgium, France, and IDA are supporting an extensive technical assistance program to improve public financial management. The World Bank Group, the Netherlands and USAID, among other donors, are supporting private sector institutional-capacity building and growth. Belgium has provided support to the Audit Court, while IDA facilitated the training of 98 staff from various ministries in the implementation of the new procurement law.

29. The government is committed to the ongoing reform program of the central bank. In this regard, it has adopted a number of laws and measures to improve the transparency of financial transactions, including a new central bank law guaranteeing its independence and an anti-money laundering law. The IMF is supporting these reforms through technical assistance and capacity building.

30. In view of the progress outlined above, the IDA and IMF staffs conclude that this trigger has been implemented.

\section{F. Demobilization}

31. The National Program for Demobilization, Reinsertion and Reintegration (PNDRR) constitutes a critical element of Burundi's peace and stabilization process. It provides the necessary instruments to facilitate implementation of the government's commitments as expressed in its Letter of Demobilization Policy. The PNDRR aims to: (i) provide demobilization support and reintegration services for a maximum of 55,000 combatants from the Forces armées du Burundi (FAB), the Parties et Mouvements politiques armés (PMPA), and subsequently, the Forces de défense nationale (FDN - the Burundian national army); (ii) provide reinsertion support to an estimated 20,000 Gardiens de la Paix and 10,000 Militants combattants; and (iii) contribute to the reallocation of government defense expenditure to the social and economic sectors. An additional target group of Police nationale was added for program support in 2006. Ultimately, the project would provide a social and economic safety net to facilitate reduction in the size of the Burundi National Defense Force and the Burundi National Police to 25,000 and 15,000 members respectively.

\section{Significant progress has been made in meeting the original objectives of the}

PNDRR. The implementation of the PNDRR has been very complex, and progress has been slower than expected mainly because the ceasefire agreement with the last remaining rebel group, the FNL, was signed late in the process and a power-sharing agreement between the two 
parties was reached only in December 2008. Nonetheless, all 23,022 adult personnel discharged by the ministries of Defense and Interior that were accepted into the PNDRR were demobilized and received a full course of reinsertion allowances. Of these adults, 22,024 (96 percent) received socio-economic reintegration support. In addition, 3,261 children were released from armed groups and reunified with their families, and 3,015 received a reinsertion allowance. The PNDRR also disbanded the Gardiens de la paix and Militants combattants, providing 28,379 individuals with reinsertion allowances. The final size of the army and police has been assessed by the Ministries of Defense and Interior at 26,588 active duty army personnel and 17,161 police members, reasonably close to the respective targets of 25,000 and $15,000{ }^{2}$

Table 3. Burundi: Progress Under the National Program for Demobilization, Reinsertion and Reintegration

(As of November 2008)

\begin{tabular}{|c|c|c|c|c|c|c|c|c|c|c|}
\hline \multirow[t]{2}{*}{$\begin{array}{l}\text { Beneficiary } \\
\text { Group }\end{array}$} & \multicolumn{2}{|c|}{$\begin{array}{c}\text { Number of } \\
\text { Beneficiaries }\end{array}$} & \multicolumn{4}{|c|}{ Caseload Processed } & \multicolumn{4}{|c|}{ Caseload Remaining } \\
\hline & Maximum & Identified & $\begin{array}{l}\text { Demo- } \\
\text { bilization }\end{array}$ & $\begin{array}{l}\text { Rein- } \\
\text { sertion }\end{array}$ & $\begin{array}{l}\text { Rein- } \\
\text { tegration }\end{array}$ & Medical & $\begin{array}{l}\text { Demo- } \\
\text { blization }\end{array}$ & $\begin{array}{l}\text { Rein- } \\
\text { sertion }\end{array}$ & $\begin{array}{l}\text { Rein- } \\
\text { tegration }\end{array}$ & Medical \\
\hline $\begin{array}{l}\text { Adults: FAB, } \\
\text { PMPA, FDN, } \\
\text { PNB }\end{array}$ & 55,000 & 23,022 & 23,022 & 23,022 & 22,024 & -- & 0 & 0 & 1,055 & -- \\
\hline $\begin{array}{l}\text { Adults: } \\
\text { Gardiens de } \\
\text { la Paix, } \\
\text { Militants } \\
\text { Combattants }\end{array}$ & 30,000 & 28,383 & 28,383 & 28,383 & $\mathrm{n} / \mathrm{a}$ & -- & 0 & 0 & $\mathrm{n} / \mathrm{a}$ & -- \\
\hline $\begin{array}{l}\text { Children } \\
\text { (all groups) }\end{array}$ & 8,000 & 3,261 & 3,261 & 3,015 & 3,015 & -- & 0 & 246 & 246 & -- \\
\hline \multirow[t]{2}{*}{$\begin{array}{l}\text { Handicapped } \\
\text { (all } \\
\text { groups)1/, /2 }\end{array}$} & 4,140 & 3,743 & -- & -- & 2,161 & 1,782 & -- & -- & 1,200 & 1,950 \\
\hline & & & & & & & 0 & 220 & 2,501 & 1,950 \\
\hline
\end{tabular}

Sources: Burundi authorities; and IDA staff estimates.

$1 /$ Because this caseload includes individuals from all groups, their reinsertion and reintegration support are reflected in overall adult demobilization and reintegration figures.

2/ Handicapped ex-combatants may receive a combination of medical and specialized or general reintegration assistance.

\section{An additional demobilization and reintegration program may be required for two} armed groups in the near to medium term. The first is the Forces nationales de libérationPalipehutu (FNL). Although the FNL was included in the original PNDRR targets, the FNL signed a ceasefire agreement with the government in July 2007 and a power-sharing agreement in December 2008. The timing and actual number of FNL combatants to be demobilized are still unknown. ${ }^{3}$ The second group is the self-identified FNL "dissidents," comprising

\footnotetext{
${ }^{2}$ Census results for the military and police are pending.

${ }^{3}$ Estimates of the size of the FNL range from 3,000 to 21,100 combatants.
} 
3,321 individuals who were granted legal status as an armed group eligible for demobilization by presidential decree in August 2008. Any future demobilization exercise targeting the FNL or FNL-dissidents would need to be accompanied by the integration of some of their personnel into Burundi's national security forces. The financial implication of the expansion of these forces is unclear. A comprehensive reform of the security sector can, among other things, address issues of army and police "right-sizing".

34. The precise modalities for continued DRR activities are under consideration. There is a consensus among the government, the World Bank, and other donors on the need for continued financial and technical support for DRR efforts beyond December 31, 2008, when the PNDRR closes. The World Bank is preparing a US $\$ 10$ million follow-up grant to the Emergency Demobilization and Reintegration Program (EDRP) for launch in FY 2009. ${ }^{4}$ The Netherlands, the EU, Norway and Belgium have expressed interest in continuing to support Burundi in this endeavor. Security sector reform (SSR) discussions are underway, and any further large-scale reductions in army and police will likely occur within a wider SSR framework.

\section{In the opinion of the IDA and IMF staffs, the trigger on demobilization has been} substantially implemented. Full compliance with the trigger was not possible mainly because the ceasefire agreement with the last remaining rebel group, the FNL, was signed late in the process and a power-sharing agreement was reached only in December 2008. In view of these considerations, staffs recommend that a waiver be granted for the non-observance of this trigger.

\section{G. Structural Measures}

36. The government has made substantial progress in reforming the coffee sector and is moving toward the tendering for sale of the state holdings in a majority of coffee washing stations. The authorities have prepared a comprehensive coffee-sector reform action plan that includes institutional and regulatory changes. The consultative reform approach ensures that the proposed course of action is likely to be accepted by stakeholders and therefore to be successfully implemented.

37. The reform of the coffee sector is multifaceted and socially and politically sensitive. It involves, among other things, a number of critical reform measures, information sharing with stakeholders, and consensus building. The authorities at the highest level have underscored the need for restructuring the sector with the goal of improving and diversifying farmers' income. This will require improved competitiveness in the coffee market and increased focus on high

\footnotetext{
${ }^{4}$ The Emergency Demobilization and Reintegration Program (EDRP) will be closing at end-December 2008. It consists of an IDA grant of US\$35.8 million and parallel financing from a multi-donor trust fund of up to US\$41.8 million.
} 
value-added cultures, which have a better potential to increase the share of revenues benefiting the most vulnerable. ${ }^{5}$

38. The reform of the coffee sector has been the subject of careful assessment leading to the adoption of a sectoral action plan. The authorities have undertaken several key studies with the help of donors (EU and IDA) and in March 2006, created the Coffee Reform Steering Committee. The government adopted a sectoral action plan in November 2006, a key element of which was the development of a strategy for the privatization or divestiture of 133 washing stations. The coffee sector reform action plan also entails strengthening the leadership provided by the Coffee Reform Committee and clarifying its mandate, enriching public information and understanding, and addressing practical bottlenecks to changes in the ownership structure and regulatory framework.

39. Important steps have been taken to reform the coffee sector. In May 2007, the President declared that coffee producers were owners of coffee beans (cherry and green), thereby confirming the right of producers to make their own decisions regarding marketing. The authorities proceeded to liberalize coffee marketing and in April 2008 moved to clarify the marketing rules by issuing a new regulation for the commercialization of green coffee for the 2008-09 season. This regulation has been advertised widely to inform producers and other stakeholders of the available marketing options, such as direct sale to buyers. As of November 2008, 22 exporters had licenses and were active participants in the market. About 7,500 metric tons of coffee beans have been sold and farmers are receiving a price based on current international prices.

40. Significant efforts have been made toward the public sector's divestiture from the coffee sector. A divestiture study was undertaken by consultants, providing the authorities with a number of divestiture options. Following wide-ranging consultations with stakeholders (farmers associations and their federal unions, NGOs, donors, potential private bidders, and owners of the washing stations and the drill mill company (SODECO)), the authorities chose the option that foresees the division of the 133 washing stations in 29 lots of 3-6 washing stations and their subsequent sale through a competitive bidding process. According to this option, 75 percent of the government's stake would be sold to the private sector and 25 percent would be allocated to farmer organizations. Because the latter lack the financial resources to purchase the allocated shares immediately, institutions such as the International Finance Corporation (IFC), microfinance institutions, and international financial NGOs, would hold these shares for a period

\footnotetext{
5 Two studies were performed as background work for the study on the sources of rural growth in Burundi. The first assessed the potential to develop production and sales of specialty coffee from Burundi (Integrative Report in Support of the Burundi Coffee Value Chain Diagnostic and Strategy Development, Michigan State University (MSU), February 2007), while the second identified candidates for fast-tracking privatization pilots (Burundi Coffee Pilot Selection and Planning, MSU, June 2007).
} 
of two years before transferring them to farmer organizations. This option was adopted by the Ministerial Council in December 2008. Implementation is expected to begin with the 2009/10 coffee season.

41. The authorities are developing a complementary organizational and regulatory framework to improve the competitiveness and profitability of the coffee sector. The new regulatory framework foresees, among other, new arrangements to ensure continued financing of purchased inputs and rules consistent with the new ownership structure for coffee processing activities.

42. In the opinion of the IDA and IMF staffs, the coffee sector trigger has been substantially implemented. Full compliance with the trigger is taking longer because of the more extensive nature of the reform process chosen by the authorities (not envisaged by the completion point trigger). The proposed course of action is more likely to be successfully implemented, given its endorsement by all major stakeholders. Staffs are of the view that the completion point should not be delayed until the divestiture is completed, given the adoption by the Ministerial Council of a divestiture plan. In view of all these considerations, staffs recommend that a waiver be granted for the non-observance of this trigger.

\section{H. Social SECTOR REFORMS}

\section{Education}

43. The authorities have made great efforts to address the country's weak educational outcomes in the post-conflict era. In November 2005, in response to a government request, donors (i.e., Belgium, France, IDA, the United Kingdom, UNICEF, the World Food Programme, and several NGOs) engaged in a process to jointly help the government: (i) develop an Education Sector Plan (ESP) to be endorsed by the Education for all Fast-Track Initiative (EFA FTI); and (ii) provide urgent funding to support education during the emergency period (2005-07). The development of the EFA FTI Education Sector Plan is already well advanced.

44. Considerable progress has been made in increasing the school enrollment rate in primary education. The elimination of primary school fees in September 2005 resulted in a large increase in first grade enrollment. The gross primary school enrollment rate rose from an estimated 77 percent in 2003/04 to 114 percent in 2006/07. The gender parity index improved markedly from 0.75 in 2003/04 to 0.87 in 2006/07. Based on administrative data, most provinces with lower than average enrollment rates in 2004 experienced an enrollment growth higher than the increase in the national rate over the same time period. Nevertheless, the quality of education needs to be improved markedly. In 2007, repetition rates were around 30 percent, while survival rates were still low at 67 percent of the primary school student population. 
45. Modest progress has been made in gross enrollment rates in secondary education. The latest and most reliable data suggest that the gross enrollment rate has increased from 12 percent (instead of 16 percent cited in the HIPC decision point document) in 2003/04 to 16 percent in 2006/2007. The overall number of students has doubled in four years. Nevertheless, the gender equity index has dropped slightly in the first two years and has remained flat at 0.72 percent in 2005/06. The repetition rate has increased from 14 percent in $2001 / 02$ to 18 percent in 2005/06. Regional secondary enrollment data were not available to assess whether the average increase in provinces with lower than average enrollment rates in 2004 was higher than the increase in the national rate over the same time period.

Table 4. Burundi: Gross School Enrollment Rates, 2001/02-2006/07

(Percent)

\begin{tabular}{lrrrrrr}
\hline & $2001 / 02$ & $2002 / 03$ & $2003 / 04$ & $2004 / 05$ & $2005 / 06$ & $2006 / 07$ \\
\hline Primary & 67 & 72 & 77 & 82 & 103 & 114 \\
Secondary & 8 & 10 & 12 & 13 & 14 & 16 \\
\hline
\end{tabular}

Sources: Burundi authorities; and IDA staff estimates.

\section{Health}

46. The government has shown strong commitment to reversing the damage done to the health of the population by more than a decade of conflict. The country's National Health Development Plan (NHDP) aims to: (i) reduce maternal and neonatal mortality; (ii) reduce infant and child mortality and morbidity; (iii) reduce the prevalence of communicable and noncommunicable diseases; and (iv) reinforce the performance of the national health system. In May 2006 the President announced the elimination of user fees for health services for children under 5 and women during delivery.

47. The government has made efforts to improve the national immunization rate. Over the past years, the government engaged in routine vaccination programs as well as in targeted vaccination campaigns to improve immunization rates among children under 1 . The authorities are stepping up efforts in this area, and more broadly in the area of health services. The government completed one vaccination campaign in June 2008 and is expected to complete a second one by end- 2008 .

48. Despite these commendable efforts, vaccination coverage data suggest that the targeted immunization rate has not been achieved. Projections for 2008, based on administrative data provided by authorities, show that only one out of five immunization rates would reach the targeted 85 percent coverage. In particular, data show an immunization rate of 91 percent for BCG, 81 percent for DTC-HepB-Hib3, 78 percent for VAR, 79 percent for Polio 
and 70 percent for VAT. In addition, administrative data are likely to overestimate actual progress and are not comparable to the original HIPC decision point baseline based on official UNICEF/WHO data. ${ }^{6,7}$ The latter suggest no significant changes since 2004 . The lack of surveybased national and provincial data since 2005 does not permit verification of actual achievement rates, or assessment of whether differences in coverage among provinces have been reduced between 2004 and 2006/07. It is hoped that the next "Micro Indicators Cluster Survey" (MICS) in 2009 will shed more light into the immunization rate statistics.

49. The key reason for the relatively low vaccination coverage is the general weakness and insufficient financing of the health system in a country with continued internal conflict. Efforts at reforming the health system have often suffered from repeated outbreaks of internal conflict. Although financing for vaccines has generally been sufficient in recent years, financing for operational costs upon which vaccination depends (cold chain, personnel, and fuel for outreach) has been more erratic. The lack of adequate resources and personnel in health facilities, in conjunction with low staff motivation, has reduced incentives to actively seek children for routine immunization.

50. The government has announced several measures to boost vaccination coverage in 2009. Following the completion of the vaccination campaign in December 2008, the government will create incentives for routine vaccinations in the second half of 2009 by including them in the "free services" package and by simplifying and improving reimbursements. Among other, the reimbursement mechanism will give a performance bonus for certain activities, including vaccination. The improvement of the reimbursement mechanism as well as the increase in available "free services" will be financed through an IDA grant under preparation. The government will also commit additional resources in the area of statistics with the objective of obtaining accurate and reliable data.

51. Future challenges are daunting. Given the current status of health indicators, it is unlikely that Burundi will meet the health-related MDGs and NHDP goals without significant increases in the volume, allocative efficiency and transparency of resources.

\section{Staffs of IDA and the IMF conclude that the trigger on the social sectors has been} partially implemented. In the education sector, there has been satisfactory progress at the national level, but provincial data for secondary education were not available for an assessment. In the health sector, staffs are cognizant of the government's commitment to improving health

\footnotetext{
${ }^{6}$ The official UNICEF/WHO data adjust administrative data with results from other sources.

${ }^{7}$ Administrative data are systematically above survey data for a number of reasons, including: poor knowledge of the denominator, poor verification of a child's age (children over 1 were counted as children under 1), and counting multi-dose vials instead of actual children. The lack of survey-based national and provincial data since 2005 does not permit correction of administrative data at this point.
} 
services but note the general challenges posed by a weak health system in a country with continued internal conflict. To address the shortcomings in the health sector, the government will: (i) include vaccination services in the improved "free-services" package; and (ii) commit additional resources in the area of statistics with the objective of obtaining accurate and reliable data, at the national and provincial levels. In view of these considerations, staffs recommend that a waiver be granted for the partial implementation of this trigger.

\section{Debt Management}

53. Debt management capacity has improved. The Ministry of Finance now has the exclusive right to negotiate and sign external loans. A computerized foreign debt management system (SYGADE) has been installed and can produce monthly debt reports. The central bank collects and gathers debt statistics. Years of civil war have resulted in poor records on Burundi's indebtedness. The main impediment to debt management continues to be the lack of human resources. To address these weaknesses, the authorities undertook a restructuring of the unit at the Ministry of Finance (DDE) in charge of managing public debt.

\section{Production of monthly external debt reports has contributed to more timely} execution of debt-service obligations. The authorities have produced monthly external debt reports, including projections for the upcoming three months, for at least six months prior to the completion point. Partly as a result of better planning, the authorities have managed to execute their debt service obligations broadly as planned. Given its high indebtedness, Burundi has agreed to rely on grants and highly concessional loans to meet its financing needs.

55. Progress has been made on normalizing relations with external creditors. Bilateral agreements with Paris Club creditors have been signed. Burundi has been negotiating with nonParis Club creditors to obtain debt relief on terms compatible with the HIPC Initiative.

56. Domestic debt management has improved. Since the conclusion of the audit of domestic arrears in 2006, the government has started repaying amounts owed to creditors according to a schedule that the government has agreed with the IMF.

57. In view of the progress achieved so far, the IDA and IMF staffs conclude that this trigger has been implemented.

\section{Debt Relief ANd Debt Sustainability AnAlysis}

\section{A. Updated Data Reconciliation AND ReVision OF AsSistance}

58. The debt stock at end-2004 has been revised upward relative to the decision point estimate. Staffs of IDA and the IMF, together with the Burundi authorities, have reviewed the debt stock at end-2004 against creditor statements. The nominal debt stock at end-December 2004 has increased from US\$1,384.1 million to US\$1,386.6 million, while the NPV of debt after 
delivery of traditional debt relief has increased by US\$6.8 million to US\$908.8 million (Table 6). The revisions arose primarily from data discrepancies discovered during the debt reconciliation process and the recalculation of the concessionality of arrears clearance operations. The main revisions are as follows:

- Multilateral creditors. The NPV of debt to the AfDB Group and the Bank of Development of the States of the Great Lakes (BDEGL) has been revised slightly upward as a result of revised debt service projections as well as revisions to the concessionality of the arrears clearance operation. Similarly, the NPV of debt to the EU has been revised upward by US\$1.3 million to reflect a revision of the concessionality of their arrears clearance operation. The NPV of debt to the Arab Bank for Economic Development in Africa (BADEA) has been revised upward by US\$0.3 million to reflect the effort made by the authorities in the arrears clearance operation. Finally, the NPV of debt owed to the International Fund for Agricultural Development (IFAD) has been revised upward from US\$18.3 million to US\$19.8 million due to a revision of debt service projections.

- Bilateral creditors. The NPV of debt to France after delivery of traditional debt relief has been revised upward by US\$2.4 million. The NPV of debt to other Paris Club creditors has been revised slightly to reflect more accurate data available at the completion point.

59. The three-year average of exports of goods and services used to evaluate HIPC assistance at the decision point has been revised downward marginally, from an average of US\$50.9 million as estimated at the decision point, to US\$50.8 million. ${ }^{8}$

60. The changes to the debt and exports data, imply an upward revision in the amount of HIPC debt relief. Based on the revised debt and exports data, the NPV of debt-to-exports ratio after traditional debt relief is estimated at 1,789.2 percent, compared to $1,772.3$ percent at the time of the decision point. The implied common reduction factor will increase from 91.54 percent in the decision point document to 91.62 percent. The amount of HIPC debt relief required to bring the NPV of debt-to-exports ratio down to the HIPC threshold of 150 percent is estimated at US\$832.6 million, compared to US\$825.7 million in the decision point document. ${ }^{9}$

\footnotetext{
${ }^{8}$ The revision of export data reflects updated staff estimates.

${ }^{9}$ The suggested change in the amount of HIPC debt relief (US\$6.8 million) is larger than the minimum threshold required for revision of HIPC assistance and is not attributable to incorrect information on exports, gross domestic product or fiscal revenues that was not provided by or at the behest of the authorities. The targeted NPV of debt after HIPC debt relief at the time of the decision point was estimated at US\$88.4 million. The minimum threshold for Burundi is therefore US\$0.884 million, or 1 percent of the target NPV of debt after HIPC debt relief.
} 


\section{B. Status of Creditor Participation in the Enhanced HiPC Initiative}

61. Burundi has received financing assurances of participation in the enhanced HIPC Initiative from creditors representing 96 percent of the NPV of HIPC assistance estimated at the decision point. Most multilateral and Paris Club creditors have confirmed their participation in the HIPC Initiative and the authorities are working toward reaching agreements with all remaining creditors (Table 9).

\section{Multilateral creditors}

62. The amount of HIPC assistance from multilateral creditors is US\$705.8 million in NPV terms or 85 percent of total HIPC assistance (Table 7). IDA, the IMF, the AfDB Group, and the EU, have provided interim assistance. The OPEC Fund for International Development (OFID) and BADEA have also provided part of their share of HIPC debt relief through their arrears clearance operations during the interim period.

63. IDA. Debt relief from IDA amounts to US\$425.2 million in NPV terms at the decision point. Of this amount, IDA has already delivered US\$68.5 million in NPV terms through a 90 percent reduction of debt service falling due during the interim period. Upon reaching the completion point, IDA would provide the remaining portion of its assistance, amounting to US\$356.7 million in NPV terms, through a 90 percent reduction of debt service on eligible debt until January 2039.

64. IMF. At the decision point, the IMF committed HIPC Initiative assistance of SDR 19.262 million (US\$27.84 million) in NPV terms. As a result of the slight upward revision in the amount of HIPC assistance, there will be a marginal revision in HIPC assistance to SDR19.28 million (US\$27.9 million) in NPV terms at the decision point. The IMF has already provided about SDR0.26 million (nominal terms) in the form of interim assistance. At the completion point, the IMF will provide the remaining amount of its share of HIPC assistance through a stock-of-debt operation estimated at SDR21.9 million. IMF assistance represents an average reduction of 56.9 percent of debt service on eligible debt (Table 15).

65. AfDB Group. HIPC relief from the AfDB Group amounts to US\$150.2 million in NPV terms. Of this amount, the AfDB Group has already provided US\$26.3 million through a concessional arrears clearance operation and US\$20.7 million in HIPC interim debt relief. ${ }^{10}$ At the completion point, the AfDB Group is assumed to provide the remaining amount of relief (US\$103.2 million) through a reduction of debt service on eligible debt.

\footnotetext{
${ }^{10}$ This assumes that the AfDB Group will continue providing interim debt relief until the expected completion point. The AfDB Group suspended HIPC debt relief in April 2008. It is expected that debt relief will resume shortly and that the AfDB Group will provide retroactive HIPC debt relief for the period during which assistance was suspended.
} 
66. Other multilateral creditors. The modalities of assistance by all other multilateral creditors (EU, IFAD, OFID, and BADEA) are summarized in Table 9.

\section{Bilateral and commercial creditors}

67. Paris Club creditors have agreed in principle to provide their share of assistance (US\$88 million in 2004 NPV terms) under the enhanced HIPC Initiative. Interim assistance has been provided through a flow treatment under Cologne terms, as agreed on September 15, 2005. Participating Paris Club creditors declared their readiness in principle to provide their full share of assistance through a stock-of-debt operation at the completion point, provided Burundi maintained satisfactory relations with participating creditors. Bilateral agreements have been signed with most Paris Club creditors with the exception of Russia, with whom Burundi has exchanged draft agreements. ${ }^{11}$ Most creditors have also indicated that they would provide additional assistance beyond HIPC relief, estimated at about US\$5 million in end-2007 NPV terms. $^{12}$

68. Non-Paris Club bilateral creditors are expected to provide HIPC assistance comparable to that of the Paris Club estimated at US\$33 million in 2004 NPV terms. While the authorities are currently negotiating HIPC-comparable rescheduling and arrears clearance with non-Paris Club creditors, some creditors have already provided part of their assumed share of HIPC debt relief. $^{13}$

69. Commercial creditors are expected to provide treatment comparable to that of the Paris Club. Nevertheless, as of end-2007 Burundi was in the process of settling all its obligations to commercial creditors. ${ }^{14}$

\section{CONSIDERATION FOR EXCEPTIONAL TOPPING UP OF HIPC ASSISTANCE}

70. The enhanced HIPC Initiative framework allows for the provision, on an exceptional basis, of additional debt relief (or "topping-up") at the completion point. Additional debt relief is provided if a country's actual debt burden indicators have deteriorated

\footnotetext{
${ }^{11}$ The consolidation period has been extended over time to June 30, 2009.

${ }^{12}$ Austria has already cancelled its claims on Burundi. Japan has partially cancelled some of its claims in addition to its rescheduling agreement.

${ }^{13}$ The People's Republic of China and Saudi Arabia are among the non-Paris Club bilateral creditors which provide debt relief on a case by case basis. During the interim period, the People's Republic of China cancelled all of Burundi's obligations. A new rescheduling agreement was signed with Libya; however, its terms are below those expected under the HIPC Initiative. Kuwait agreed to settle Burundi's arrears following the completion point. Negotiations with Abu Dhabi and Saudi Arabia are pending.

${ }^{14}$ The last payment to an Israeli commercial creditor was in July 2008 and a final payment to a German creditor is to be paid in December 2008.
} 
compared to the decision point projection and this deterioration is primarily attributable to a fundamental change in a country's economic circumstances due to exogenous factors. Additional debt relief may in this case be provided to bring the NPV of debt-to-exports ratio down to the 150 percent threshold at the completion point. ${ }^{15}$

71. Burundi's nominal stock of external debt reached US\$1,466.4 million at end-2007, compared with US\$1,386.6 million at end-2004 (Table 10). ${ }^{16}$, Multilateral creditors accounted for 86.1 percent of total debt, while bilateral and commercial creditors for 13.9 percent. ${ }^{17}$ IDA, the AfDB Group and France remain Burundi's largest creditors, accounting for 57 percent, 14.8 percent and 7.2 percent respectively of total outstanding debt.

72. The NPV of Burundi's external debt at end-2007, after full delivery of the assistance committed under the HIPC Initiative at the decision point, is estimated at US\$175.4 million, equivalent to 195.7 percent of exports. Of this amount, US\$166.6 million is owed to multilateral creditors and US\$5.2 million to Paris Club creditors.

\section{Burundi's NPV of debt-to-exports ratio after full delivery of HIPC assistance at} end-2007 is 30.9 percentage points higher than what was projected at the decision point. At the decision point, the NPV of debt-to-exports ratio after full delivery of HIPC debt relief at end2007 was projected to be 164.8 percent compared to 195.7 percent, which is the actual ratio. However, the decision point projections were revised in line with the methodological requirements of the HIPC Initiative. ${ }^{18}$ As a result of these changes, the NPV of debt projected at the decision point was revised upward to 180.4 percent at end-2007, reducing the difference between the actual and projected NPV of debt-to-exports ratio to 15.2 percentage points (Table 5). Finally, assuming delivery of debt relief by bilateral creditors beyond HIPC assistance would reduce the NPV of debt-to-exports ratio from 195.7 percent (after full delivery of HIPC assistance) to 190.3 percent. The NPV difference compared to the decision point would be reduced to only 9.9 percentage points of exports. ${ }^{19}$

\footnotetext{
${ }^{15}$ To date, six countries have received topping-up assistance under the enhanced HIPC Initiative: Burkina Faso, Ethiopia, Rwanda, Malawi, Niger and Sao Tome and Principe.

${ }^{16}$ The debt stock covers public and publicly guaranteed external debt outstanding and disbursed.

${ }^{17}$ This corresponds to a full reconciliation of multilateral debt data and a 99 percent reconciliation of bilateral and commercial debt data at end-2007.

${ }^{18}$ The revisions to the NPV of debt-to-exports ratio (after full delivery of HIPC debt relief) do not translate into a revision of the amount of debt relief to be delivered to Burundi in the context of the HIPC Initiative.

${ }^{19}$ Assessment of the external debt situation at the completion point should take into account not only enhanced HIPC Initiative assistance, but also additional debt forgiveness provided and/or committed by official bilateral and commercial creditors.
} 


\section{Compared to recent cases, the deterioration in the NPV of debt-to-exports ratio} relative to the decision point projection is fairly modest. In particular, the unanticipated increase in the NPV of debt to-exports ratio was 102.6 percentage points of exports in the case of The Gambia; 159 percentage points of exports in the case of Sao Tomé and Principe;

72.1 percentage points of exports in the case of Sierra Leone; 76.0 percentage points of exports in the case of Malawi; 133.3 percentage points of exports in the case of Rwanda; 60.3 percentage points of revenues in the case of Honduras; and 23.4 percentage points of exports in the case of Zambia. ${ }^{20}$ The Gambia, Sierra Leone, Honduras, and Zambia did not receive topping up.

Table 5. Burundi: Breakdown of the Increase in the NPV of Debt-to-Exports Ratio at end-2007

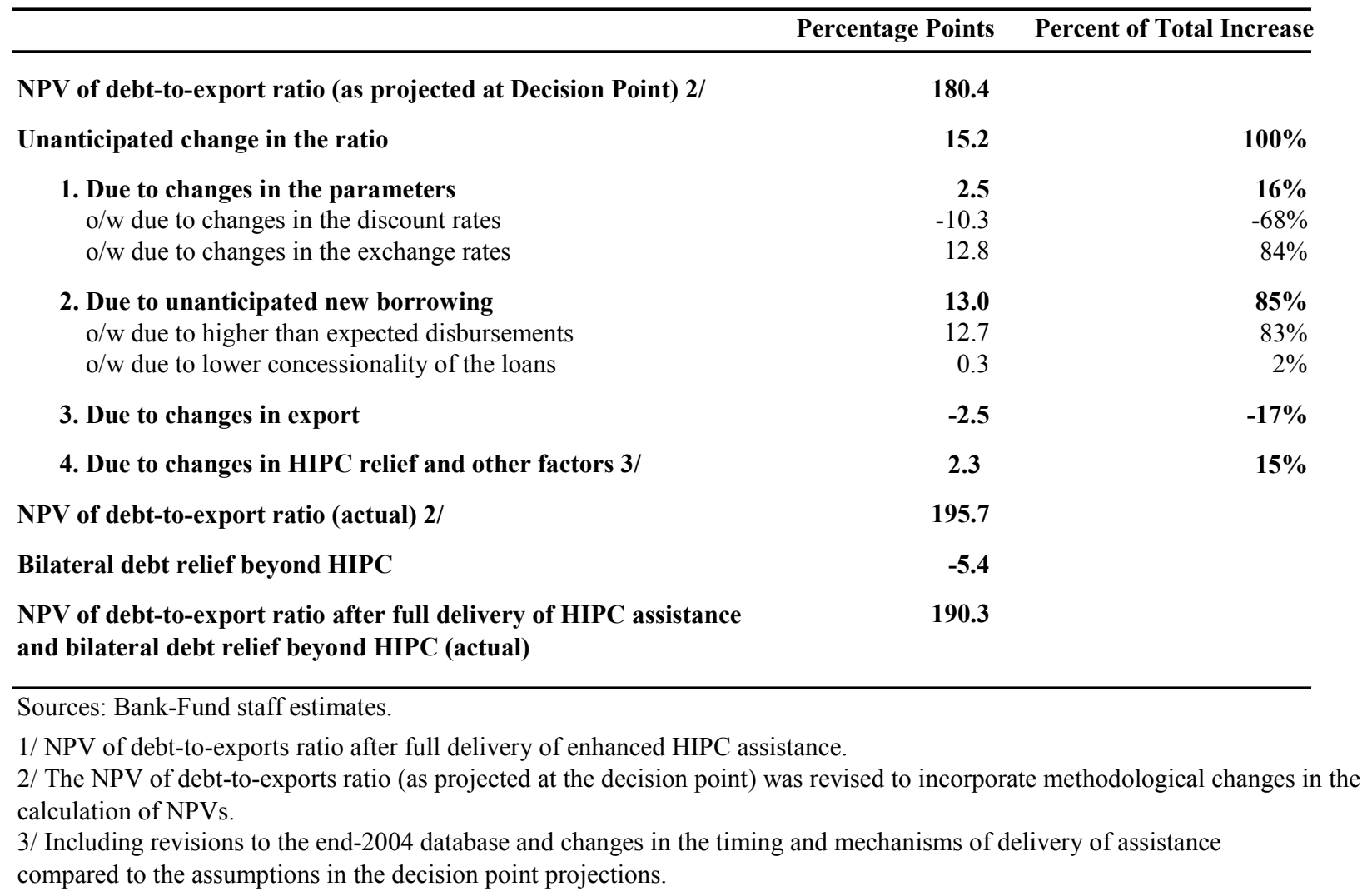

\section{The NPV of debt-to-exports ratio after HIPC assistance is higher than what was} projected at the time of the decision point, mainly due to higher than expected new borrowing. Higher than expected borrowing compared to the decision point projection accounts for about 85 percent of the total increase in the NPV of debt-to-exports ratio after full delivery of HIPC assistance (but before bilateral debt relief beyond the HIPC Initiative). In particular, new borrowing from end-2004 to end-2007 was expected to amount to US\$83.7 million in end-2004

\footnotetext{
${ }^{20}$ This does not include the impact of bilateral debt relief beyond HIPC.
} 
NPV terms according to projections at the decision point. ${ }^{21}$ Instead, it amounted to US\$95.3 million. This increase mainly reflects faster-than-expected disbursements from multilateral creditors associated with on-going operations (not fully disbursed loans), rather than new loan agreements. The decision point projection appears to have been based on a historical disbursement rate, which underestimated the potential new borrowing after the decision point. The concessionality of new borrowing was broadly in line with the decision point projection. Staffs consider that the higher than expected new borrowing is not in response to an exogenous shock, as it reflects an underestimation of the disbursement ratio of projects already started before end-2004, which should have been forecasted at the time of the decision point.

76. Unanticipated changes in exchange rates and discount rates explain 16 percent of the deterioration in Burundi's NPV of debt-to-exports ratio. The depreciation of the US dollar, which contributed to a deterioration of 12.8 percentage points in the NPV of debt-toexports ratio, was almost completely offset by an increase in discount rates, which contributed to a decline of 10.3 percentage points.

77. Exports were stronger than anticipated at the time of the decision point. Higher exports contributed to an improvement in Burundi's NPV of debt-to-exports ratio by 2.5 percentage points, compared to the decision point projection.

78. The staffs are of the view that Burundi does not meet the requirements for exceptional topping-up under the enhanced HIPC Initiative. Staffs consider the deterioration in the NPV of debt-to-exports ratio, after taking into account additional debt relief, to be fairly modest, and therefore not primarily attributable to a fundamental change in Burundi's economic circumstances due to exogenous factors. In addition, the most important factor contributing to the increase (higher than expected new borrowing) is not considered to be in response to an exogenous shock.

\section{Creditor Participation in the Multilateral DebT Relief Initiative}

79. Contingent upon approval of the completion point under the enhanced HIPC Initiative, Burundi will qualify for additional debt relief under the Multilateral Debt Relief Initiative (MDRI). ${ }^{22}$ MDRI relief would be provided by IDA, the IMF and the AfDF.

80. Debt relief from IDA. IDA would provide debt relief under the MDRI amounting to US\$98.3 million in nominal terms (Table 16). IDA would provide MDRI debt forgiveness by

\footnotetext{
${ }^{21}$ See "Burundi HIPC Debt Initiative: Decision Point Document”, IMF Country Report No. 05/329, September 3, 2005 and IDA/R2005-0174, Table 7.

${ }^{22}$ Decisions to grant debt relief are taken by each institution individually, in accordance with the specific implementation modalities adopted by each institution.
} 
irrevocably canceling Burundi's payment obligations for credits disbursed before end-2003 and still outstanding on March 31, 2009. MDRI debt relief from IDA would imply average debt service savings (net of HIPC assistance) of US\$2.89 million per year over the next 34 years. Burundi's debt stock owed to IDA would be reduced by US\$90.4 million on April 1, 2009.

81. Debt relief from the IMF. The IMF will provide debt relief under the MDRI amounting to SDR 9.2 million, covering the full stock-of-debt owed to the IMF at end-2004 that remains outstanding at the completion point after the full delivery of HIPC debt relief (Table 15). ${ }^{23}$

82. Debt Relief from the AfDF. The AfDF would provide debt relief to Burundi under the MDRI amounting to US\$13.9 million in nominal terms, starting on February 1, 2009. This amount is calculated based on debt disbursed as of December 31, 2004 and still outstanding on January 31, 2009. The debt stock cancellation, estimated at US\$12.6 million, would be delivered by forgiving in full Burundi's post-completion-point repayment obligations.

\section{E. Debt Sustainability Outlook, 2008-27}

\section{The macroeconomic framework underpinning the medium- to long-term debt} sustainability outlook has been revised to take into account recent developments (Table 19). Over the medium term, the macroeconomic framework is in line with the government's mediumterm program supported under the current PRGF arrangement. Long-term assumptions are based on World Economic Outlook (WEO) prices, recent trends, and information provided by the authorities on sectoral strategies. The main elements of the long-term macroeconomic framework underpinning the debt sustainability analysis are outlined in Box 3.

\section{The revised framework is predicated on continued consolidation of the peace} process, strong donor involvement over the medium term, and a deepening of structural reforms. The near-term economic outlook is influenced by the international financial crisis. Real GDP growth is projected to grow by 4.5 percent, down by half percentage point from projections made in June 2008. The downward revision reflects weaker global demand owing to the ongoing global financial crisis. ${ }^{24}$ GDP growth is expected to average about 5 percent over the long term, based on: (i) continued removal of economic distortions, especially in the coffee sector, which will help boost total factor productivity; (ii) a substantial increase in investment which will help relieve supply bottlenecks; and (iii) advances in trade liberalization including in the context of the East African Community, which will help diversify the economy, stimulate competition and attract investment. Real GDP growth might be driven also by the re-launching of productive activities by returning refugees and demobilized combatants. Exports are projected to drive

\footnotetext{
${ }^{23}$ As defined in the MDRI-I Trust Instrument.

${ }^{24}$ Staffs will continue to monitor the impact of the unfolding global financial crisis on Burundi and advise the authorities on the appropriate policy response.
} 
growth over the long term, with the development of traditional sectors such as coffee, tea, and cotton, and the gradual diversification into nontraditional exports such as horticulture, fruits, vegetables, and tourism. Import volume will be strong in the medium term reflecting reconstruction efforts and the implementation of structural reforms. Donor support will be critical to finance the external current account deficit over the medium term. Fiscal policy will be anchored by the need to safeguard debt sustainability while being supportive of growth. It is assumed that the authorities will continue to make efforts to widen the tax base and increase revenues to offset the gradual decline in donor support over the long term. Improving the quality of spending will be important for improving the delivery of services over the medium term, in view of the need to safeguard fiscal sustainability. Continued demobilization efforts would provide more fiscal space for poverty-reducing spending. Monetary policy will focus on controlling inflation, within a flexible exchange rate system. Because international oil prices are falling, end-of-period headline inflation is estimated to have peaked in 2008 and is expected to decline to 9 percent in 2009. Inflation will further decline to about 6 percent by 2011 . With the objective of a single-digit inflation rate, the central bank will set the broad money growth rate below the nominal GDP growth rate to help anchor inflation expectations. The central bank will use all available monetary and exchange rate instruments to mop up liquidity.

85. The macroeconomic outlook is subject to vulnerabilities. Burundi is a net importer of food and oil products, which constitute 25 percent of total imports, and its position as a landlocked country raises import costs. It has been among the economies hit hardest by the surge in global food and oil prices, with an estimated balance of payments impact of about 4 percent of GDP. The surge in food and oil prices had also led to increased inflation, as discussed above.

\section{Adverse shocks-political, social, security or economic-could lead to a} considerable deterioration of economic and external debt conditions. Among the most likely are: (i) stronger-than-expected adverse effects of the international financial crisis-i.e., declining coffee prices and sharply lower aid flows;(ii) unexpectedly high international food and oil prices; and (iii) spending pressure stemming from higher-than expected costs of demobilizing and reintegrating the last rebel group.

\section{Full delivery of HIPC and MDRI debt relief at the completion point would} significantly reduce Burundi's external public debt. In NPV terms, the debt stock would be reduced from US\$911 million at end-2008 to US\$150 million at end-2009 (Table 11). Nominal debt service relief in 2009 would amount to US\$46.0 million, of which US\$3.7 million would be related to MDRI (Table 12). 


\section{Box 3: Main Macroeconomic Assumptions, 2008-27}

Real GDP growth is expected to accelerate to 5 percent over the medium term reflecting the consolidation of peace, the reform of the coffee sector, and economic stimulus from increased capital spending associated with donor support. Long-term growth is expected to be about 5 percent. Investment is expected to average about 16 percent of GDP, a level considered to be supportive of long-term economic growth.

Inflation is assumed to decline gradually over the medium term and stabilize at about 4 percent over the long term, as the central bank moves to strengthen its policy instruments.

Fiscal policy would be supportive of economic growth and poverty reduction, while maintaining debt sustainability and macroeconomic stability.

- Government revenues, excluding grants, are projected to remain rather stable over the medium term, but gradually increase to about 21 percent of GDP over the long term. This increase reflects primarily a widening of the tax base as a result of continued tax administration reforms.

- Government expenditure is expected to gradually decline over time to the more sustainable level of about 27 percent of GDP. This path is consistent with a gradual reduction of current spending growth, and higher pro-poor spending. Public investment is expected to gradually decline over time to about 4 percent of GDP as the private sector becomes the engine of growth.

Exports of goods and services are projected to increase by an average of 7 percent over the medium term reflecting in part lower commodity prices; they are projected to increase by 9-10 percent over the longer term as investment in key export sectors (traditional and nontraditional) begins to yield results. In volume terms, exports of goods are projected to gradually increase.

Imports of goods and services will gradually decelerate over time to a more sustainable rate of 5 percent. With emergency and reconstruction-related imports winding down and oil prices declining over the medium term, merchandise import volumes in the outer years are expected to move broadly in line with real GDP growth.

Current account deficit, including grants, is expected to deteriorate to about 17 percent of GDP in 2015, and then gradually decline to about 9 percent at the end of the projection period. Excluding transfers, the current account deficit is assumed to decline from 26 percent of GDP to about 9 percent at the end of the projection period. The authorities will rely largely on highly concessional loans to finance the current account deficit.

External financing will increasingly rely on loans in the long term, as grants gradually subside. Grant support is assumed to decline from about 26 percent of GDP in 2008 to about 10 percent in 2015 as humanitarian assistance gradually declines. Loans are assumed to gradually decline from about 3 percent of GDP in 2008 to about 1 percent at the end of the projection period. Borrowing is assumed to take place primarily on highly concessional terms. 
88. Burundi's external public debt burden indicators are expected to remain high over the medium term (Table 13). After HIPC and MDRI assistance, the NPV of debt-to-exports ratio is expected to drop from 967 percent at end-2007 to 148 percent at end-2009. It would subsequently rise to 169 percent by end-2011, before continuing on a slow downward trend, reaching 75 percent by the end of the projection period. After HIPC and MDRI assistance, the NPV of debt-to-GDP ratio is expected to decline from 89 percent at end-2007 to 11 percent at end-2009. By the end of the projection period, the NPV of debt-to-GDP ratio is expected to reach 7 percent.

89. After delivery of HIPC assistance, Burundi's debt service is projected to remain at 3-4 percent of government revenues until 2011. Thereafter, Burundi's debt-service-to-revenue ratio is expected to increase slightly owing to large principal repayments during 2012-17. By the end of the projection period, Burundi's debt-service-to-revenue ratio is expected to decline to 2 percent. After additional bilateral and MDRI relief, debt service would not exceed 5 percent of revenues throughout the projection period.

\section{F. Sensitivity Analysis AND Long-Term Debt SustainabiLity}

90. Burundi's external debt situation could deteriorate considerably over the projection period if faced with adverse shocks. Burundi's debt sustainability outlook depends on maintaining a stable external environment, continued donor support over the medium term, and implementation of structural reforms. If these conditions fail to materialize, Burundi's external debt burden indicators are expected to deteriorate considerably.

\section{Scenario 1: Terms-of-trade shock}

91. This scenario assumes a permanent decline in the export price of coffee by 20 percent and a simultaneous permanent increase in the import price of oil by 17 percent. ${ }^{25}$ The terms-of-trade shock leads to a reduction in nominal exports of about 8.4 percent in 2009 , slowly deteriorating to about 15 percent by the end of the projection period. Given the coffee sector's contribution to the economy and the impact of oil on Burundi's productive base, output is adversely affected. The government is assumed to resort to additional borrowing on concessional terms to finance the revenue shortfall. As a result, the NPV of debtto-exports ratio rises rapidly, reaching 217 percent by 2011. Under this scenario, the NPV of debt-to-exports ratio is more than 100 percentage points higher than the baseline by 2027 (Figure 3).

\footnotetext{
${ }^{25}$ These percentages correspond to the average price deviation for these commodities during the past 20 years.
} 


\section{Scenario 2: Lower donor support}

92. Lower donor support may result from governance concerns, donor fatigue, or the tight fiscal position in many donor countries related to the recent international financial crisis. Under this scenario, it is assumed that foreign grants are cut by 25 percent during 2009-15. The government is assumed to resort to additional borrowing on concessional terms to finance the ensuing financing gap. As a result, the NPV of debt-to-exports ratio initially increases rapidly, peaking at 256 percent by 2015 . Thereafter, the NPV of debt-to-exports ratio slowly declines, reaching 119 percent by 2027, or approximately 45 percentage points higher than the baseline scenario.

\section{Scenario 3: Lower growth}

93. This scenario assumes a permanent reduction in real GDP growth by one percentage point relative to the baseline scenario, as a result of slower implementation of structural reforms, a weakening global demand owing to the international financial crisis, or governance concerns. Underlying this assumption is a slower expansion and diversification of the export base (e.g., coffee sector liberalization and development of nontraditional sectors), and reduced investment. The volume of exports is permanently reduced, while import volume adjusts in line with the reduction in real GDP growth. As lower growth has a negative net effect on public finances, it is assumed that the government closes the financing need through additional borrowing on concessional terms. Under this scenario, the NPV of debtto-exports ratio continuously deteriorates, reaching 343 percent, or approximately 270 percentage point higher than under the baseline scenario.

94. The results of the sensitivity analysis underscore the importance of continued prudent fiscal and debt management policies. It will be imperative that the authorities implement the reforms needed to support continued donor involvement, higher investment, and export diversification. Given the immense social needs, the authorities should intensify efforts to expand the tax base so as to avoid excessive debt accumulation in the presence of adverse exogenous shocks. The authorities should also continue to follow prudent borrowing policies by relying on grants and highly concessional loans.

\section{Conclusions}

95. In the opinion of IDA and IMF staffs, Burundi has met the requirements established in August 2005 for reaching the completion point under the enhanced HIPC Initiative.

96. In the opinion of IDA and IMF staffs, Burundi has made satisfactory progress in implementing the reforms specified for reaching the completion point. It has implemented six out of nine triggers and made good progress in implementing the other three- the triggers on demobilization, the coffee sector and social sectors. The demobilization, reinsertion and 
reintegration program has substantially met the majority of its goals, with the final size of the army and police reasonably close to the respective targets of 25,000 and 15,000. A ceasefire agreement with the last remaining rebel group, the FNL, was signed late in the process and a power-sharing agreement was signed only in December 2008. Regarding the tendering for sale of the state holdings in a majority of coffee washing stations, the authorities chose to implement a more ambitious reform of the coffee sector than envisaged at the decision point. Given its broad endorsement by major stakeholders, it is more likely to be accepted by stakeholders and therefore to be successfully implemented. Regarding the trigger on social sectors, the staffs note the satisfactory progress in education at the national level; however data for secondary education at the provincial level were not available for an assessment. In the health sector, staffs recognize the government's strong commitment to improving health services and vaccination coverage in particular, but note the general weaknesses of the health system in a country with continued internal conflict. To partially address these shortcomings, the government will: (i) include vaccination services in the improved "free services" package starting in 2009; and (ii) commit additional resources in the area of statistics with the objective of obtaining accurate and reliable data at the national and provincial levels.

97. Revisions to the end-2004 debt and export data imply an upward revision in the amount of HIPC debt relief. Based on the revised debt and export data, the NPV of debt-toexports ratio (after traditional debt relief) at end-2004 is estimated at 1,789.2 percent, compared to $1,772.3$ percent at the time of the decision point. The amount of HIPC debt relief required to bring the NPV of debt-to-exports ratio down to the HIPC threshold of 150 percent is estimated at US\$832.6 million (in end-2004 NPV terms), compared to US\$825.7 million in the decision point document. Assurances of participation in the enhanced HIPC Initiative have been obtained by creditors representing 96 percent of the total NPV of HIPC assistance estimated at the decision point.

98. Staffs are of the view that Burundi does not meet the requirements for exceptional topping-up under the enhanced HIPC Initiative. They consider the deterioration in the NPV of debt-to-exports ratio, after taking into account additional debt relief, to be fairly modest, and therefore not primarily attributable to a fundamental change in Burundi's economic circumstances due to exogenous factors. In addition, the most important factor contributing to the increase (higher than expected new borrowing) is not considered to be in response to an exogenous shock.

99. Burundi's debt burden will decrease significantly after it receives enhanced HIPC assistance and MDRI debt relief. However, Burundi's external public debt indicators are expected to remain high over the medium term. After HIPC and MDRI assistance, the NPV of debt-to-exports ratio is expected to decline from 967 percent at end-2007 to 148 percent at end-2009. It would subsequently rise to 169 percent by end-2011, before continuing on a slow downward trend, reaching 75 percent by the end of the projection period. The sensitivity analysis 
underscores the importance of continued prudent fiscal and debt management policies, including securing grant financing and highly concessional loans, and structural reforms to support diversified and broad-based growth.

100. In light of the above, the staffs recommend that the Executive Directors determine that Burundi has reached the completion point under the enhanced HIPC Initiative.

\section{ISSUES FOR DISCUSSION}

101. Executive Directors may wish to consider this report in terms of the following questions:

- Completion point. Do Directors agree that Burundi has reached the completion point under the enhanced HIPC Initiative?

- Data Revision. Do Directors agree with staffs' recommendation that the proposed revision in the stock of debt in NPV terms warrants a revision in the amount of HIPC assistance? Do IMF Directors agree with the upward revision in IMF HIPC assistance from SDR19.262 million to SDR19.28 million?

- $\quad$ Topping-up. Do Directors agree that Burundi does not meet the requirements for exceptional topping-up at the completion point?

- MDRI/HIPC debt relief. Do IMF Directors agree that Burundi qualifies for an amount of debt relief by the IMF equal to SDR 31.1 million, of which an estimated SDR 9.2 million would be financed from the MDRI-I Trust, and the rest from Burundi's HIPC Umbrella sub-account?

- Creditor Participation. Do Directors agree that Burundi creditors have given sufficient assurances to irrevocably commit HIPC Initiative assistance to Burundi? 
Figure 1. Burundi: Composition of the Stock of External Debt by Creditor Group
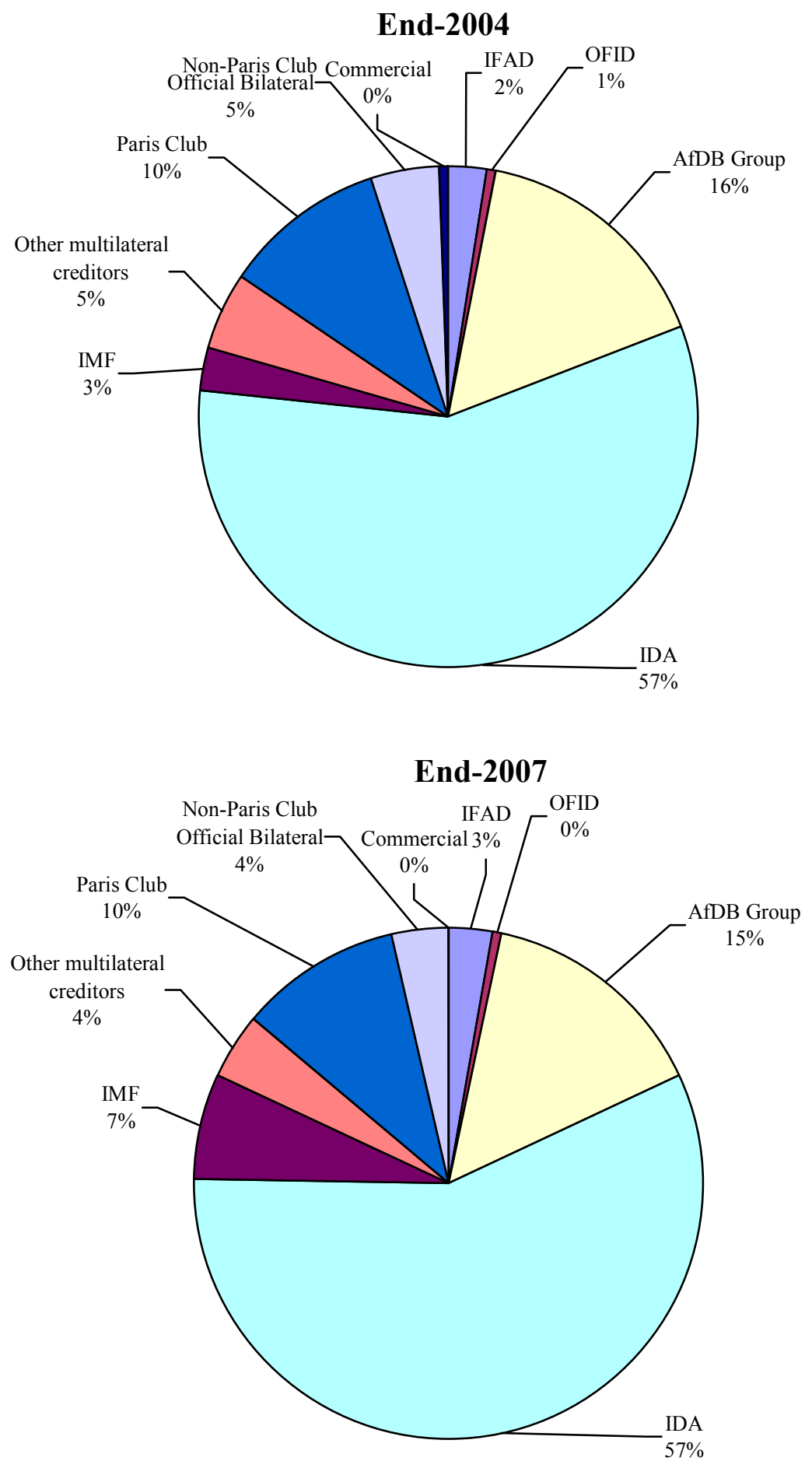

Sources: Burundi authorities; and Bank-Fund staff estimates. 
Figure 2. Burundi: External Debt and Debt Service Indicators

(For Medium- and Long-Term Public Sector Debt, 2007-27)

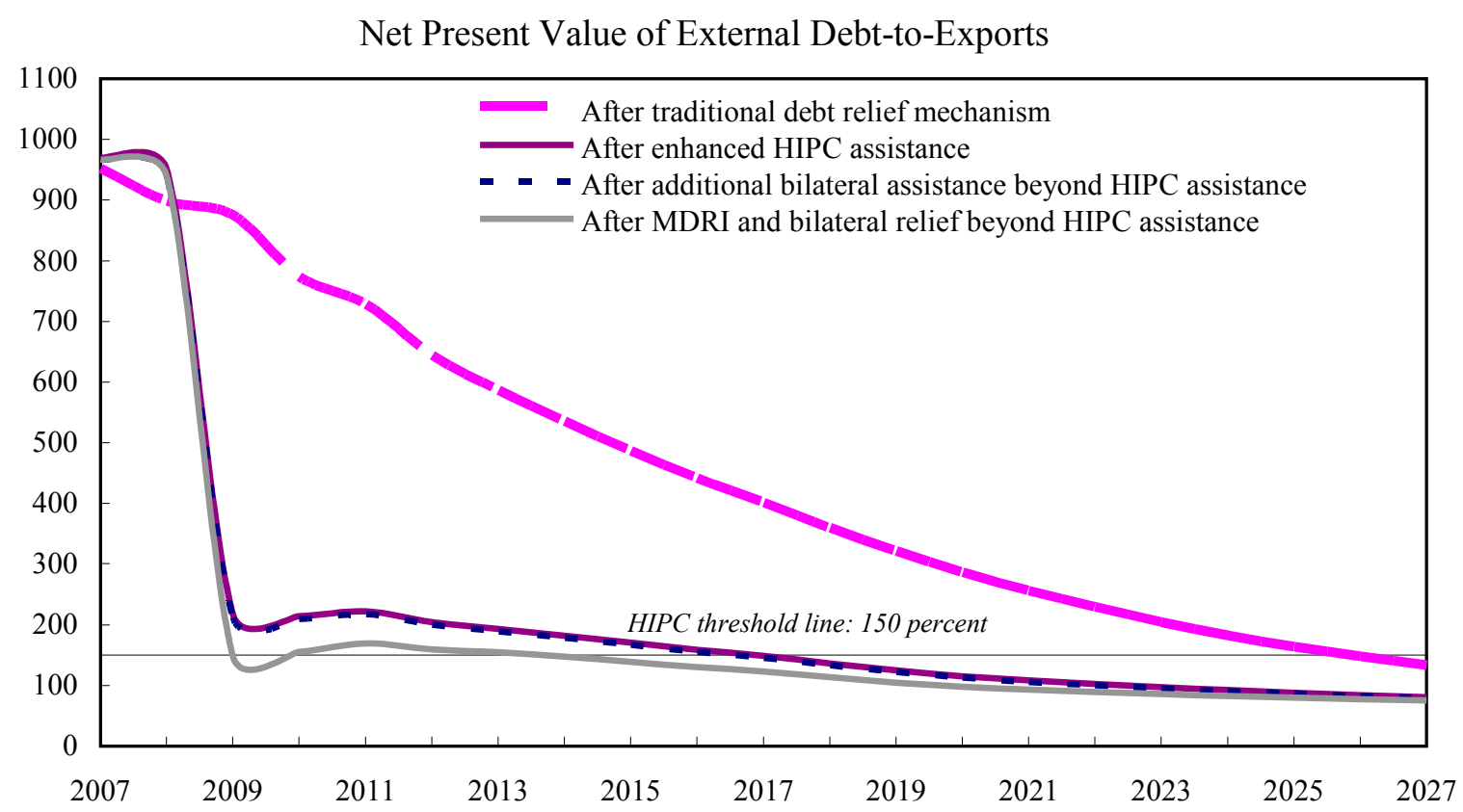

Debt Service-to-Exports

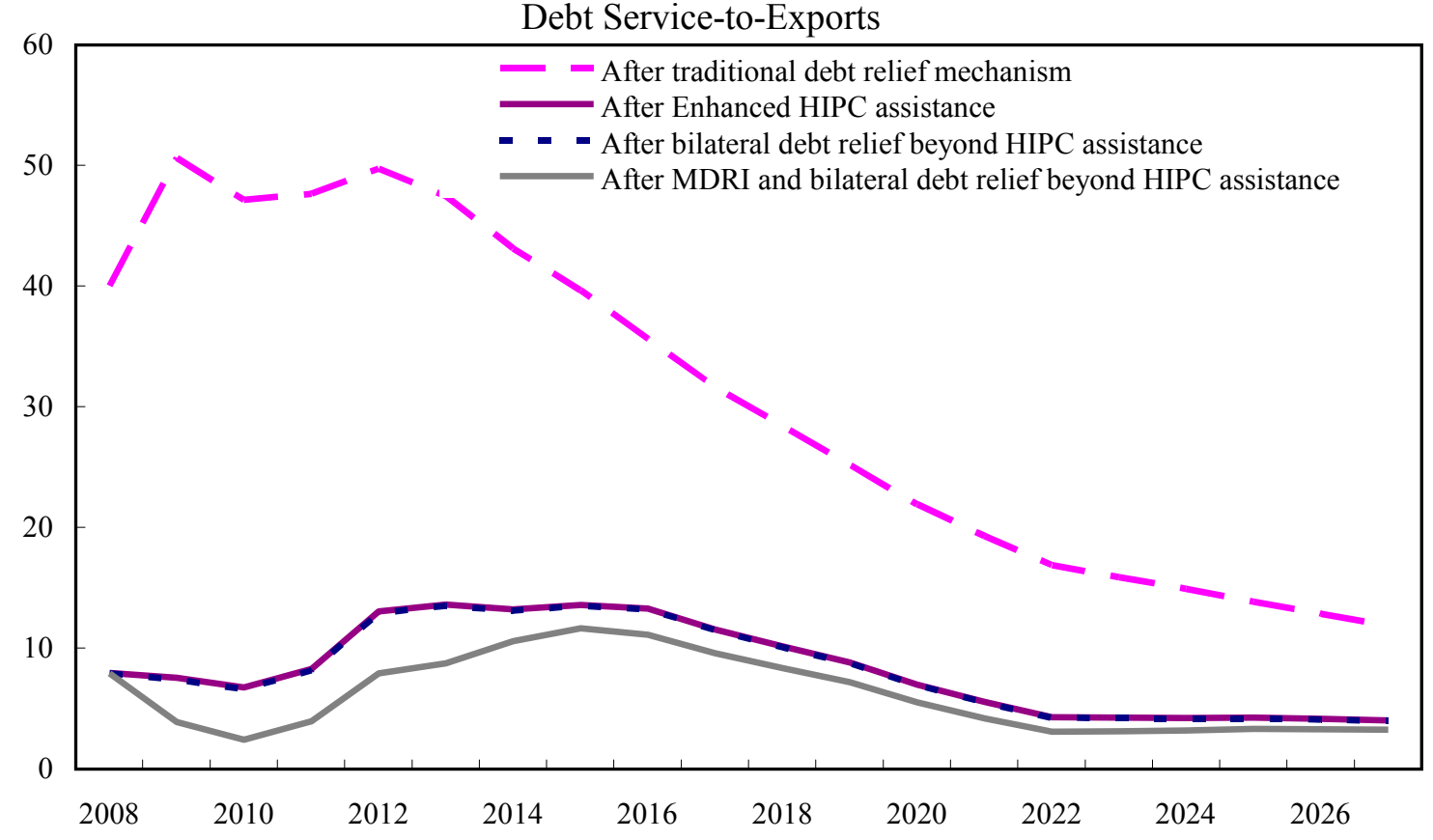

Sources: Burundi authorities; and Bank-Fund staff estimates and projections. 
Figure 3. Burundi: Sensitivity Analysis, 2008-27
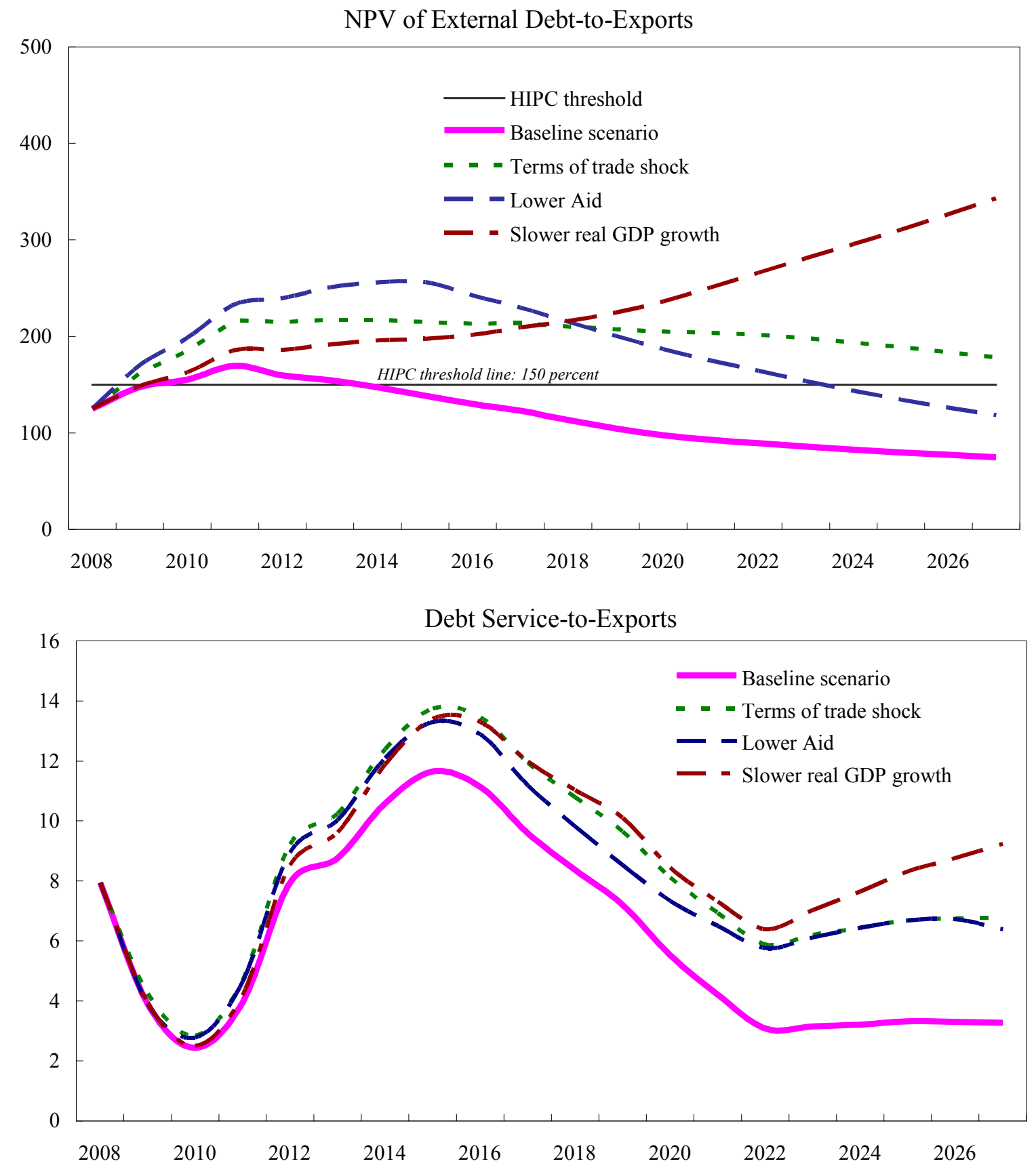

Sources: Burundi authorities; and Bank-Fund staff estimates. 
Table 6. Burundi: Revised Nominal Stock and Net Present Value of Debt at the Decision Point by Creditor Groups at end-December, 2004 1/

\begin{tabular}{|c|c|c|c|c|c|c|c|c|c|c|c|c|}
\hline & \multicolumn{4}{|c|}{ Nominal Debt Stock at End-December, 2004} & \multicolumn{4}{|c|}{ NPV of Debt Before Rescheduling 2/ } & \multicolumn{4}{|c|}{ NPV of Debt After Rescheduling 2/ } \\
\hline & \multicolumn{2}{|c|}{ At Decision Point } & \multicolumn{2}{|c|}{$\begin{array}{c}\text { Revised At } \\
\text { Completion Point }\end{array}$} & \multicolumn{2}{|c|}{ At Decision Point } & \multicolumn{2}{|c|}{$\begin{array}{c}\text { Revised At } \\
\text { Completion Point } \\
\end{array}$} & \multicolumn{2}{|c|}{ At Decision Point } & \multicolumn{2}{|c|}{$\begin{array}{c}\text { Revised At } \\
\text { Completion Point } \\
\end{array}$} \\
\hline & US\$ million & $\begin{array}{l}\text { Percent } \\
\text { of total }\end{array}$ & US\$ million & $\begin{array}{l}\text { Percent } \\
\text { of total }\end{array}$ & US\$ million & $\begin{array}{l}\text { Percent } \\
\text { of total }\end{array}$ & US\$ million & $\begin{array}{l}\text { Percent } \\
\text { of total }\end{array}$ & US\$ million & $\begin{array}{l}\text { Percent } \\
\text { of total }\end{array}$ & US\$ million & $\begin{array}{l}\text { Percent } \\
\text { of total }\end{array}$ \\
\hline Total & $1,384.1$ & 100 & $1,386.6$ & 100 & 894.8 & 100 & 897.8 & 100 & 902.0 & 100 & 908.8 & 100 \\
\hline Multilateral & $1,169.9$ & 85 & $1,172.4$ & 85 & 713.8 & 80 & 716.3 & 80 & 766.3 & 85 & 770.4 & 85 \\
\hline AfDB Group & 223.8 & 16 & 223.8 & 16 & 140.1 & 16 & 139.3 & 16 & 163.2 & 18 & 163.9 & 18 \\
\hline AfDB & 5.9 & 0 & 5.9 & 0 & 6.1 & 1 & 5.9 & 1 & 15.0 & 2 & 15.5 & 2 \\
\hline AfDF & 217.2 & 16 & 217.2 & 16 & 133.4 & 15 & 132.8 & 15 & 147.4 & 16 & 147.8 & 16 \\
\hline NTF & 0.7 & 0 & 0.7 & 0 & 0.7 & 0 & 0.6 & 0 & 0.7 & 0 & 0.7 & 0 \\
\hline IMF & 41.0 & 3 & 41.0 & 3 & 30.4 & 3 & 30.4 & 3 & 30.4 & 3 & 30.4 & 3 \\
\hline EU-EIB & 51.0 & 4 & 51.0 & 4 & 35.1 & 4 & 35.1 & 4 & 62.2 & 7 & 63.6 & 7 \\
\hline IFAD & 30.3 & 2 & 33.2 & 2 & 18.3 & 2 & 19.8 & 2 & 18.3 & 2 & 19.8 & 2 \\
\hline BADEA & 16.9 & 1 & 16.9 & 1 & 14.5 & 2 & 16.9 & 2 & 16.9 & 2 & 17.3 & 2 \\
\hline OFID & 10.1 & 1 & 10.1 & 1 & 10.0 & 1 & 10.0 & 1 & 10.0 & 1 & 10.0 & 1 \\
\hline Official bilateral and commercial & 214.2 & 15 & 214.2 & 15 & 181.0 & 20 & 181.6 & 20 & 135.7 & 15 & 138.4 & 15 \\
\hline Paris Club & 145.1 & 10 & 145.1 & 10 & 115.2 & 13 & 115.0 & 13 & 93.7 & 10 & 96.4 & 11 \\
\hline Post-cutoff date & - & - & - & - & - & - & - & - & - & - & - & - \\
\hline Pre-cutoff date & 145.1 & 10 & 145.1 & 10 & 115.2 & 13 & 115.0 & 13 & 93.7 & 10 & 96.4 & 11 \\
\hline Of which: ODA & 142.9 & 10 & 142.9 & 10 & 112.8 & 13 & 112.7 & 13 & 91.3 & 10 & 94.1 & 10 \\
\hline Non-ODA & 2.2 & 0 & 2.2 & 0 & 2.4 & 0 & 2.3 & 0 & 2.4 & 0 & 2.3 & 0 \\
\hline \multicolumn{13}{|l|}{ Of which: } \\
\hline Austria & 16.8 & 1 & 16.8 & 1 & 8.2 & 1 & 8.2 & 1 & 3.8 & 0 & 3.8 & 0 \\
\hline Belgium & 0.0 & 0 & 0.0 & 0 & 0.0 & 0 & 0.0 & 0 & 0.0 & 0 & 0.0 & 0 \\
\hline Denmark & 0.0 & 0 & 0.0 & 0 & 0.0 & 0 & 0.0 & 0 & 0.0 & 0 & 0.0 & 0 \\
\hline France & 90.5 & 7 & 90.5 & 7 & 70.6 & 8 & 70.5 & 8 & 59.8 & 7 & 62.2 & 7 \\
\hline Germany & 0.4 & 0 & 0.4 & 0 & 0.3 & 0 & 0.3 & 0 & 0.1 & 0 & 0.3 & 0 \\
\hline Ireland & 0.0 & 0 & 0.0 & 0 & 0.0 & 0 & 0.0 & 0 & 0.0 & 0 & 0.0 & 0 \\
\hline Italy & 0.0 & 0 & 0.0 & 0 & 0.0 & 0 & 0.0 & 0 & 0.0 & 0 & 0.0 & 0 \\
\hline Japan & 34.7 & 3 & 34.7 & 3 & 33.4 & 4 & 33.4 & 4 & 27.4 & 3 & 27.4 & 3 \\
\hline Luxembourg & 0.0 & 0 & 0.0 & 0 & 0.0 & 0 & 0.0 & 0 & 0.0 & 0 & 0.0 & 0 \\
\hline Netherlands & 0.1 & 0 & 0.1 & 0 & 0.1 & 0 & 0.1 & 0 & 0.0 & 0 & 0.1 & 0 \\
\hline Russia & 2.2 & 0 & 2.2 & 0 & 2.4 & 0 & 2.3 & 0 & 2.4 & 0 & 2.3 & 0 \\
\hline Post-cutoff date & 5.4 & 0 & 5.4 & 0 & 5.4 & 1 & 5.4 & 1 & 5.3 & 1 & 5.3 & 1 \\
\hline Pre-cutoff date & 57.1 & 4 & 57.1 & 4 & 54.3 & 6 & 55.0 & 6 & 30.9 & 3 & 30.9 & 3 \\
\hline Of which: ODA & 48.7 & 4 & 48.7 & 4 & 46.8 & 5 & 47.0 & 5 & 28.1 & 3 & 28.1 & 3 \\
\hline Non-ODA & 8.5 & 1 & 8.5 & 1 & 7.5 & 1 & 8.0 & 1 & 2.8 & 0 & 2.8 & 0 \\
\hline \multicolumn{13}{|l|}{ Of which: } \\
\hline Abu Dhabi & 2.5 & 0 & 2.5 & 0 & 2.5 & 0 & 2.5 & 0 & 2.0 & 0 & 2.0 & 0 \\
\hline China & 13.7 & 1 & 13.7 & 1 & 12.0 & 1 & 12.7 & 1 & 4.0 & 0 & 4.0 & 0 \\
\hline Kuwait & 20.2 & 1 & 20.2 & 1 & 20.1 & 2 & 20.1 & 2 & 13.7 & 2 & 13.7 & 2 \\
\hline Libya & 5.4 & 0 & 5.4 & 0 & 5.4 & 1 & 5.4 & 1 & 5.3 & 1 & 5.3 & 1 \\
\hline Saudi Arabia & 20.7 & 1 & 20.7 & 1 & 19.7 & 2 & 19.7 & 2 & 11.1 & 1 & 11.1 & 1 \\
\hline Commercial & 6.6 & 0 & 6.6 & 0 & 6.2 & 1 & 6.2 & 1 & 5.8 & 1 & 5.8 & 1 \\
\hline Krupp, Germany & 0.5 & 0 & 0.5 & 0 & 0.5 & 0 & 0.5 & 0 & 0.2 & 0 & 0.2 & 0 \\
\hline AD Consultant, Israel & 6.1 & 0 & 6.1 & 0 & 5.7 & 1 & 5.7 & 1 & 5.7 & 1 & 5.7 & 1 \\
\hline
\end{tabular}

Sources: Burundi authorities; and Bank-Fund staff estimates.

$1 /$ Information based on latest data available at completion point.

2/ Stock of debt operation on Naples terms from official bilateral and commercial creditors. 
Table 7. Burundi: Estimated Assistance at the Decision Point (Amended) 1/ (In millions of U.S. dollars in end-December 2004 NPV terms, unless otherwise indicated) 2/

\begin{tabular}{|c|c|c|c|c|c|c|}
\hline & Total & Multilaterals & Bilaterals & $\begin{array}{c}\text { Commercial } \\
\text { Banks }\end{array}$ & $\begin{array}{l}\text { Common } \\
\text { Reduction } \\
\text { Factor 3/ } \\
\text { (Percent) }\end{array}$ & $\begin{array}{r}\text { Required NPV debt } \\
\text { reduction on } \\
\text { comparable treatment on } \\
\text { bilateral debt based }\end{array}$ \\
\hline NPV of debt-to-exports target (in percent) & 150.0 & & & & & \\
\hline $\begin{array}{l}\text { Assistance (decision point document) } \\
\text { Assistance (revised) }\end{array}$ & $\begin{array}{l}825.7 \\
832.6\end{array}$ & $\begin{array}{l}701.4 \\
705.8\end{array}$ & $\begin{array}{l}118.9 \\
121.4\end{array}$ & $\begin{array}{l}5.3 \\
5.4\end{array}$ & $\begin{array}{l}91.54 \\
91.62\end{array}$ & \\
\hline Memorandum items: & & & & & & \\
\hline $\begin{array}{l}\text { NPV of debt } 5 / 6 / \\
\text { Three-year export average } 7 / \\
\text { NPV of debt-to-export ratio (percent) 7/ } \\
\text { Revised } \\
\text { Decision point document }\end{array}$ & $\begin{array}{r}908.8 \\
50.8 \\
1,789.2 \\
1,772.3\end{array}$ & 770.4 & 132.5 & 5.8 & & \\
\hline $\begin{array}{l}\text { Bilateral Creditors: } \\
\text { Of which: pre-cod ODA } \\
\text { pre-cod non-ODA } \\
\text { post-cod debt }\end{array}$ & & & & & & $\begin{array}{l}91.6 \\
97.2 \\
91.6\end{array}$ \\
\hline
\end{tabular}

Sources: Burundi authorities; and Bank-Fund staff estimates and projections.

1/ Assumes proportional burden-sharing as described in "HIPC Initiative: Estimated Costs and Burden-Sharing Approaches," that is, after full application of traditional debt relief mechanisms.

2/ Using six-month backward-looking discount rates at end-December 2004, and end-2004 exchange rates.

3/ Each creditor's NPV reduction in percent of its exposure at the decision point (after hypothetical Naples stock at the end of the base year).

4/ Includes traditional debt relief; a hypothetical stock-of-debt on Naples terms with comparable treatment from non Paris Club creditors.

5/ After a hypothetical stock-of-debt operation on Naples terms at end-2004.

6/ Based on latest data available at the decision point after full application of traditional debt relief mechanisms.

7/ Based on the latest annual data at the completion point on the three-year average of exports of goods and nonfactor services (i.e., 2002-2004). 
Table 8. Burundi: Comparison of Discount Rate and Exchange Rate Assumptions

\begin{tabular}{|c|c|c|c|c|}
\hline & \multicolumn{2}{|c|}{$\begin{array}{l}\text { Discount Rates } 1 / 2 / \\
\text { (in percent per annum) }\end{array}$} & \multicolumn{2}{|c|}{$\begin{array}{c}\text { Exchange Rates } 3 / \\
\text { (U.S. dollar per currency) }\end{array}$} \\
\hline & $\begin{array}{l}\text { At decision point } \\
\text { End-December 200 }\end{array}$ & $\begin{array}{l}\text { on point } \\
\text { ber } 2007\end{array}$ & $\begin{array}{c}\text { At decision point } \\
\text { End-December } 2004\end{array}$ & $\begin{array}{l}\text { At completion point } \\
4 \text { End-December } 2007\end{array}$ \\
\hline \multicolumn{5}{|l|}{ Currency } \\
\hline Austrian Schillings & 4.815 & 5.350 & 0.099 & 0.107 \\
\hline Belgian Franc & 4.815 & 5.350 & 0.034 & 0.036 \\
\hline Swiss Franc & 3.477 & 3.952 & 0.884 & 0.888 \\
\hline Chinese Yuan & 4.643 & 5.290 & 0.121 & 0.137 \\
\hline Deutsche Mark & 4.815 & 5.350 & 0.696 & 0.753 \\
\hline DOM-Domestic Currency: & 4.643 & 5.290 & 0.001 & 0.224 \\
\hline Euro & 4.815 & 5.350 & 1.362 & 1.472 \\
\hline French Franc & 4.815 & 5.350 & 0.208 & 0.224 \\
\hline Great Britain Sterling & 6.012 & 6.325 & 1.931 & 2.003 \\
\hline Italian Lira & 4.815 & 5.350 & 0.001 & 0.001 \\
\hline Japanese Yen & 2.150 & 2.472 & 0.010 & 0.009 \\
\hline Kuwaiti Dinar & 5.028 & 5.643 & 3.393 & 3.663 \\
\hline Libyan Dinar & 4.643 & 5.290 & 0.804 & 0.818 \\
\hline Netherlands Guilders & 4.815 & 5.350 & 0.618 & 0.668 \\
\hline Norwegian Krone & 4.698 & 5.933 & 0.166 & 0.185 \\
\hline Russian Rouble & 4.643 & 5.290 & 1.667 & 1.667 \\
\hline Saudi Arabia Riyal & 4.643 & 5.290 & 0.267 & 0.267 \\
\hline Sweden Kronor & 4.373 & 5.305 & 0.151 & 0.156 \\
\hline United Arab Emirates Dirham & 4.643 & 5.290 & 0.272 & 0.272 \\
\hline United States Dollar & 5.028 & 5.643 & 1.000 & 1.000 \\
\hline Canadian Dollar & 5.358 & 5.418 & 0.831 & 1.012 \\
\hline CFA Franc & 4.815 & 5.350 & 0.002 & 0.002 \\
\hline Danish Krone & 4.940 & 5.388 & 0.183 & 0.197 \\
\hline Finnish Markkaa & 4.815 & 5.350 & 0.229 & 0.248 \\
\hline Irish Punt & 4.815 & 5.350 & 1.730 & 1.869 \\
\hline Portuguese Escudos & 4.815 & 5.350 & 0.007 & 0.007 \\
\hline Spanish Peseta & 4.815 & 5.350 & 0.008 & 0.009 \\
\hline Special Drawing Rights & 4.643 & 5.290 & 1.553 & 1.580 \\
\hline
\end{tabular}

Sources: European Central Bank; IMF, International Financial Statistics; OECD; and Bank-Fund staff estimates.

1/ The discount rates used are the average commercial interest reference rates (CIRRs) for the respective currencies over the six-month period ending in December 2007 for the completion point and in December 2004 for the decision point. 2/ For all Euro area currencies, the Euro CIRR is used. For all currencies for which the CIRRs are not available, the SDR discount rate is used as a proxy.

3/ End-of-period exchange rates. 
Table 9. Burundi: Status of Creditor Participation Under the Enhanced HIPC Initiative

\begin{tabular}{|c|c|c|c|c|}
\hline & $\begin{array}{l}\text { Debt Relief in } \\
\text { NPV Terms } \\
\text { (US\$ mln.) }\end{array}$ & $\begin{array}{l}\text { Percentage } \\
\text { of Total } \\
\text { Assistance }\end{array}$ & $\begin{array}{l}\text { Satisfactory } \\
\text { Reply to } \\
\text { Participate in } \\
\text { Initiative }\end{array}$ & Modalities to Deliver Debt Relief \\
\hline The World Bank Group & 425 & 51 & Yes & $\begin{array}{l}\text { Interim debt relief equivalent to a } 90 \text { percent reduction in } \\
\text { Burundi's debt service to IDA, or US } \$ 68.5 \text { million in NPV } \\
\text { terms. After completion point, the remaining assistance of } \\
\text { US } \$ 356.7 \text { million in NPV terms will be provided through a } 90 \\
\text { percent reduction in debt service payments. }\end{array}$ \\
\hline African Development Bank Group & 150 & 18 & Yes & $\begin{array}{l}\text { Interim debt relief provided from August } 2005 \text {. In addition, } \\
\text { HIPC debt relief was provided through a concessional arrears } \\
\text { clearance operation. The remaining assistance wil be } \\
\text { provided through a debt service reduction after the completion } \\
\text { point. }\end{array}$ \\
\hline EU-EIB & 58 & 7 & Yes & $\begin{array}{l}\text { Interim debt relief provided on selected loans. At Completion } \\
\text { Point the EU-EIB will provide HIPC debt relief by full or partial } \\
\text { early repayment of selected loans. }\end{array}$ \\
\hline International Monetary Fund & 28 & 3 & Yes & $\begin{array}{l}\text { Assistance to be delivered through partial payment of debt } \\
\text { service falling due to IMF by the PRGF-HIPC Trust. Interim } \\
\text { relief started as of August } 2005 \text {. The share of debt service } \\
\text { due on eligible IMF obligations covered by total IMF } \\
\text { assistance averages } 57 \text { percent over } 2005-2015 \text {. }\end{array}$ \\
\hline $\begin{array}{l}\text { International Fund for Agricultural } \\
\text { Development }\end{array}$ & 18 & 2 & Yes & $\begin{array}{l}100 \% \text { debt service relief until NPV target is achieved. Relief } \\
\text { will begin at the Completion Point. }\end{array}$ \\
\hline $\begin{array}{l}\text { Arab Bank for Economic } \\
\text { Development in Africa }\end{array}$ & 16 & 2 & Yes & $\begin{array}{l}\text { Concessional clearance of arrears during the interim period. } \\
\text { Additional HIPC debt relief will be provided after completion } \\
\text { point. }\end{array}$ \\
\hline OFID & 9 & 1 & Yes & $\begin{array}{l}\text { Concessional clearance of arrears during the interim period } \\
\text { and restructuring of existing loan on more concessional } \\
\text { terms. Remaining HIPC debt relief at completion point will be } \\
\text { provided through : (i) extension of new HIPC loan; and/or (ii) } \\
\text { restructuring of existing loans. }\end{array}$ \\
\hline BDEGL & 1 & 0 & Pending & \\
\hline Total multilateral & 706 & 85 & & \\
\hline Paris Club creditors & 88 & 11 & Yes & $\begin{array}{l}\text { Interim assistance is being provided through Cologne flow, } \\
\text { and some creditors have cancelled } 100 \% \text { of flow during } \\
\text { interim period. Stock of debt operation under cologne terms is } \\
\text { expected at completion point. Some creditors have cancelled } \\
\text { a part and some have cancelled all their claims on Burundi. }\end{array}$ \\
\hline Non-Paris Club creditors & 33 & 4 & Some & \\
\hline Kuwait & 13 & 2 & No & $\begin{array}{l}\text { The Kuwait Fund for Arab Economic Development has } \\
\text { offered an understanding by which arrears shall be cleared by } \\
\text { a special financial arrangement once Burundi reaches } \\
\text { completion point under the HIPC initiative; the authorities will } \\
\text { need to follow up with this. }\end{array}$ \\
\hline Saudi Arabia & 10 & 1 & No & $\begin{array}{l}\text { Negotiations are on going with the Saudi officials for arrears } \\
\text { clearance. }\end{array}$ \\
\hline Libya & 5 & 1 & No & $\begin{array}{l}\text { A new rescheduling agreement was signed with Libya; } \\
\text { however, the terms are below expected HIPC terms. }\end{array}$ \\
\hline People's Republic of China & 4 & 0 & Yes & $\begin{array}{l}\text { China cancelled all its loans and has delivered beyond its } \\
\text { share of HIPC relief. }\end{array}$ \\
\hline UAE & 2 & 0 & No & $\begin{array}{l}\text { The Abu Dhabi Fund for Development also offered to clear } \\
\text { the arrears in the context of a broader rescheduling of its } \\
\text { claims; however, the terms of the proposed rescheduling } \\
\text { were not HIPC comparable. }\end{array}$ \\
\hline Commercial creditors & 5 & 1 & No & \\
\hline Total bilateral and commercial & 127 & 15 & & \\
\hline Total & 833 & 100 & & \\
\hline
\end{tabular}

Sources: Burundi authorities; and Bank-Fund staff estimates. 
Table 10. Burundi: Nominal and Net Present Value of External Debt Outstanding at end-December 2007 (In millions of U.S. dollars, unless otherwise indicated)

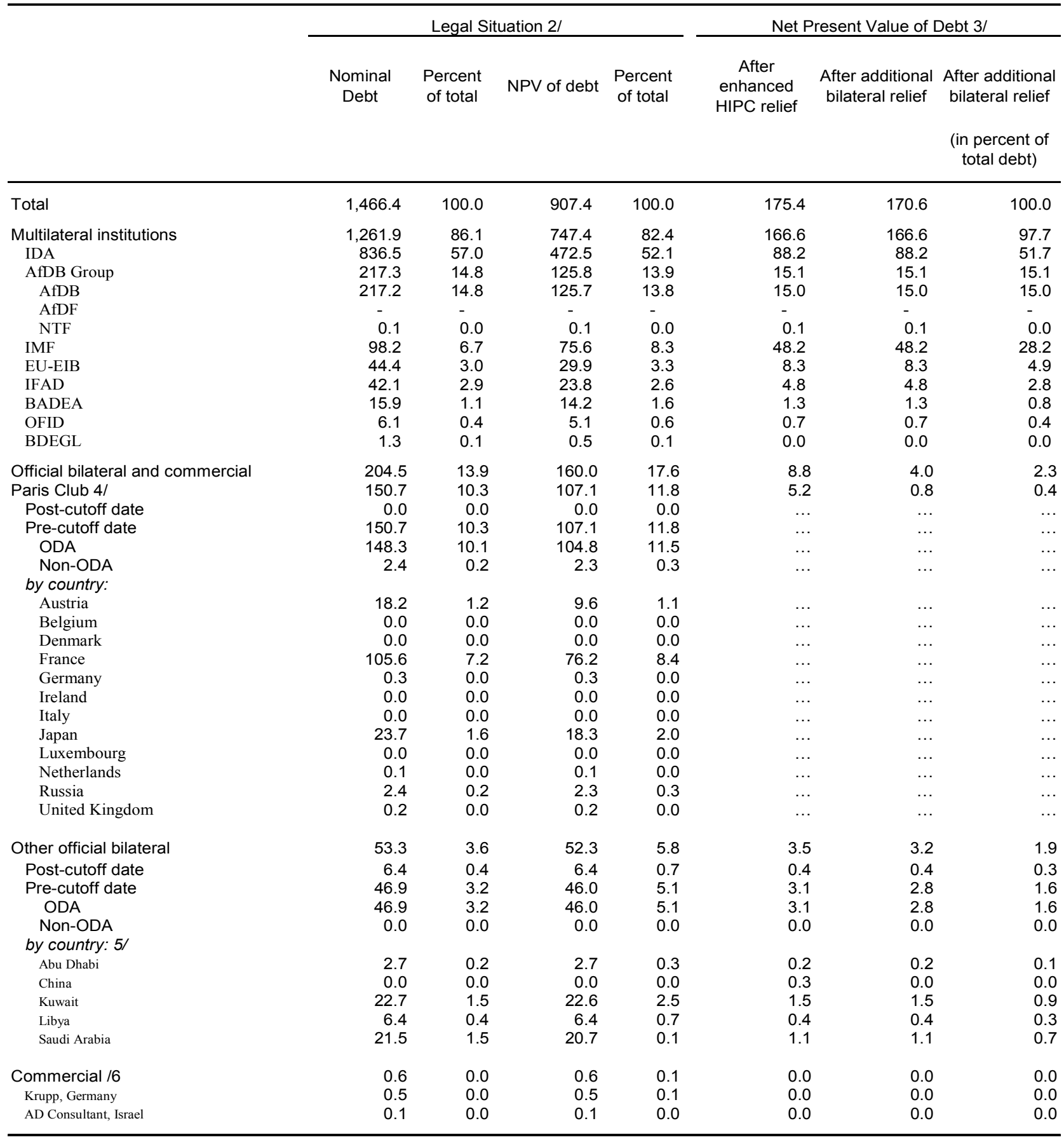

Sources: Burundi authorities; and Bank-Fund staff estimates.

1/ Figures are based on data as of end-2007.

2/ Includes Naples flows, as well as Cologne flow and cancellations from China and Japan

3/ Assumes full delivery of HIPC assistance as of end-2007. The NPV of debt for China is simulated so as to show that China has provided beyond HIPC relief to Burundi.

4/ Paris Club creditors deliver their share of assistance as a group. Actual delivery modalities are defined on a case-by-case basis. 5/ China has cancelled all its clamis on Burundi in 2007. The NPV after enhanced HIPC is a simulation of debt which is then cancelled after additional bilateral relief. Libya has cancelled the interest in arrears and has implemented a new rescheduling in February 2008. 6/ Burundi has been making payments to its commercial creditors in the interim period. 
Table 11. Burundi: Net Present Value of External Debt 1/

(In millions of U.S. dollars, unless otherwise indicated)

\begin{tabular}{|c|c|c|c|c|c|c|c|c|c|c|c|}
\hline & \multirow{2}{*}{$\begin{array}{c}\text { Actual } \\
2007\end{array}$} & \multicolumn{8}{|c|}{ Projections } & \multicolumn{2}{|c|}{ Averages } \\
\hline & & $2 \overline{008}$ & 2009 & 2010 & 2011 & 2012 & 2017 & 2022 & 2027 & $2 \overline{2007-17}$ & $2018-27$ \\
\hline \multicolumn{12}{|l|}{ I. After traditional debt-relief mechanisms 2 / } \\
\hline 1. NPV of total debt $(2+4)$ & 853 & 872 & 889 & 901 & 908 & 892 & 814 & 748 & 700 & 866 & 744 \\
\hline 2. NPV of outstanding debt & 853 & 852 & 842 & 826 & 804 & 773 & 634 & 526 & 369 & 760 & 503 \\
\hline Official bilateral and commercial & 105 & 106 & 106 & 106 & 105 & 105 & 112 & 119 & 118 & 107 & 117 \\
\hline Paris Club & 73 & 74 & 75 & 75 & 76 & 77 & 82 & 87 & 86 & 77 & 86 \\
\hline Other official bilateral and commer & 32 & 32 & 31 & 30 & 29 & 28 & 30 & 32 & 32 & 30 & 32 \\
\hline Multilateral & 747 & 745 & 736 & 721 & 699 & 668 & 522 & 407 & 251 & 653 & 386 \\
\hline World Bank Group & 472 & 471 & 468 & 463 & 456 & 448 & 385 & 302 & 180 & 440 & 284 \\
\hline IMF & 76 & 79 & 79 & 73 & 64 & 48 & 0 & 0 & 0 & 43 & 0 \\
\hline AfDB Group & 126 & 125 & 124 & 122 & 121 & 118 & 101 & 81 & 57 & 116 & 78 \\
\hline Others & 74 & 70 & 66 & 62 & 58 & 54 & 36 & 24 & 14 & 54 & 23 \\
\hline \multicolumn{12}{|l|}{ II. After enhanced HIPC assistance } \\
\hline 1. NPV of total debt $(2+4)$ & 869 & 921 & 220 & 249 & 277 & 283 & 301 & 335 & 423 & 390 & 350 \\
\hline 2. NPV of outstanding debt & 869 & 902 & 173 & 174 & 173 & 164 & 121 & 112 & 93 & 284 & 109 \\
\hline Official bilateral and commercial & 153 & 156 & 8 & 9 & 9 & 9 & 9 & 10 & 10 & 35 & 10 \\
\hline Paris Club & 100 & 104 & 5 & 5 & 5 & 5 & 5 & 6 & 6 & 23 & 6 \\
\hline Other official bilateral and commer & 53 & 52 & 4 & 4 & 4 & 4 & 4 & 5 & 5 & 13 & 5 \\
\hline Multilateral & 716 & 745 & 165 & 166 & 164 & 155 & 112 & 102 & 82 & 249 & 99 \\
\hline World Bank Group & 451 & 471 & 90 & 91 & 92 & 92 & 87 & 78 & 60 & 157 & 75 \\
\hline IMF & 75 & 79 & 48 & 48 & 47 & 38 & 0 & 0 & 0 & 35 & 0 \\
\hline AfDB Group & 120 & 125 & 15 & 15 & 15 & 15 & 14 & 12 & 10 & 34 & 12 \\
\hline Others & 70 & 70 & 12 & 11 & 11 & 11 & 11 & 12 & 12 & 22 & 12 \\
\hline 3. NPV of total debt after full delivery $3 /$ & 175 & 192 & 220 & 249 & 277 & 283 & 301 & 335 & 423 & & \\
\hline As assumed in the decision point & 146 & 163 & 180 & 196 & 207 & 214 & 256 & 319 & & & \\
\hline \multicolumn{12}{|c|}{ III. After bilateral debt relief beyond HIPC assistance 4/ } \\
\hline 1. NPV of total debt $(2+4)$ & 866 & 911 & 215 & 244 & 272 & 277 & 296 & 329 & 417 & 384 & 343 \\
\hline 2. NPV of outstanding debt & 866 & 891 & 168 & 169 & 168 & 158 & 115 & 106 & 86 & 278 & 102 \\
\hline Official bilateral and commercial & 151 & 145 & 3 & 3 & 3 & 3 & 4 & 4 & 4 & 30 & 4 \\
\hline Paris Club & 100 & 96 & 0 & 0 & 0 & 0 & 0 & 0 & 0 & 18 & 0 \\
\hline Other official bilateral and commer & 50 & 50 & 3 & 3 & 3 & 3 & 4 & 4 & 4 & 12 & 4 \\
\hline Multilateral & 716 & 745 & 165 & 166 & 164 & 155 & 112 & 102 & 82 & 249 & 99 \\
\hline World Bank Group & 451 & 471 & 90 & 91 & 92 & 92 & 87 & 78 & 60 & & \\
\hline IMF & 75 & 79 & 48 & 48 & 47 & 38 & 0 & 0 & 0 & & \\
\hline AfDB Group & 120 & 125 & 15 & 15 & 15 & 15 & 14 & 12 & 10 & & \\
\hline Others & 70 & 70 & 12 & 11 & 11 & 11 & 11 & 12 & 12 & & \\
\hline 3. NPV of total debt after full delivery $3 /$ & 171 & 187 & 215 & 244 & 272 & 277 & 296 & 329 & 417 & & \\
\hline \multicolumn{12}{|c|}{ IV. After MDRI assistance and bilateral debt relief beyond HIPC assistance } \\
\hline 1. NPV of total debt $(2+4)$ & 866 & 911 & 150 & 181 & 211 & 221 & 250 & 292 & 393 & 340 & 309 \\
\hline 2. NPV of outstanding debt & 866 & 891 & 103 & 106 & 107 & 102 & 69 & 69 & 62 & 234 & 68 \\
\hline Official bilateral and commercial $5 /$ & 151 & 145 & 3 & 3 & 3 & 3 & 4 & 4 & 4 & 30 & 4 \\
\hline Multilateral & 716 & 745 & 100 & 103 & 104 & 99 & 66 & 66 & 58 & 204 & 64 \\
\hline World Bank Group & 451 & 471 & 41 & 43 & 44 & 45 & 46 & 46 & 39 & 120 & 45 \\
\hline IMF & 75 & 79 & 39 & 41 & 41 & 35 & 0 & 0 & 0 & 33 & 0 \\
\hline AfDB Group & 120 & 125 & 8 & 8 & 8 & 8 & 8 & 8 & 7 & 29 & 8 \\
\hline Others & 70 & 70 & 12 & 11 & 11 & 11 & 11 & 12 & 12 & 22 & 12 \\
\hline 3. NPV of total debt after full delivery $3 /$ & 105 & 122 & 150 & 181 & 211 & 221 & 250 & 292 & 393 & & \\
\hline \multicolumn{12}{|l|}{ Memorandum items: } \\
\hline 4. NPV of new borrowing & $\ldots$ & 20 & 47 & 75 & 104 & 119 & 180 & 223 & 331 & 117 & 241 \\
\hline
\end{tabular}

Sources: Burundi authorities; and Bank-Fund staff estimates and projections.

$1 /$ Refers to public and publicly guaranteed external debt only and is discounted on the basis of the average commercial interest reference rate for the respective currency, derived over the six-month period prior to the latest date for which actual data are available (December 2007). 2/ Assumes a stock-of-debt operation on Naples terms (67 percent NPV reduction) as of end-2007, and at least comparable action by other official bilateral and commercial creditors.

3/ NPV of total debt assuming the entire HIPC Initiative assistance is fully delivered as of end-2007.

4/ Includes additional debt relief provided on a voluntary basis by the Paris Club and some commercial creditors beyond the requirements of the enhanced HIPC framework as specified on Table 14.

5/ This corresponds to the situation after additional bilateral relief for Paris Club Creditors. 
Table 12. Burundi: External Debt Service After Full Implementation of Debt-Relief Mechanisms (In millions of U.S. dollars, unless otherwise indicated)

\begin{tabular}{|c|c|c|c|c|c|c|c|c|c|c|}
\hline \multirow{2}{*}{ After traditional debt-relief mechanisms 1} & 2008 & 2009 & 2010 & 2011 & 2012 & 2017 & 2022 & 2027 & \multicolumn{2}{|c|}{$\frac{\text { Annual Averages }}{2008-172018-27}$} \\
\hline & & & & & & & & & & \\
\hline Total debt service including new borrowing & 45.8 & 54.1 & 60.5 & 66.3 & 73.7 & 69.7 & 60.9 & 67.6 & 66.6 & 65.3 \\
\hline Total debt service on outstanding debt & 45.5 & 53.8 & 59.9 & 65.3 & 72.4 & 53.2 & 53.8 & 54.1 & 56.4 & 53.8 \\
\hline Multilateral & 41.1 & 48.2 & 54.3 & 59.7 & 66.9 & 49.2 & 48.9 & 47.7 & 57.4 & 48.6 \\
\hline World Bank Group & 26.4 & 28.1 & 29.7 & 31.7 & 32.7 & 35.2 & 36.6 & 36.9 & 32.4 & 36.6 \\
\hline IMF & 0.4 & 4.7 & 9.9 & 13.2 & 18.8 & 1.1 & 0.0 & 0.0 & 10.1 & 0.0 \\
\hline AfDB Group & 7.1 & 7.2 & 7.1 & 7.9 & 8.3 & 8.8 & 8.5 & 7.9 & 8.1 & 8.4 \\
\hline Others & 7.3 & 8.2 & 7.5 & 6.9 & 7.1 & 4.1 & 3.8 & 2.8 & 6.8 & 3.5 \\
\hline Official bilateral & 4.3 & 5.7 & 5.6 & 5.6 & 5.5 & 4.0 & 4.9 & 6.4 & 4.7 & 5.2 \\
\hline Paris Club & 2.9 & 2.9 & 2.9 & 2.9 & 2.9 & 2.8 & 3.6 & 4.5 & 2.8 & 3.7 \\
\hline Other official bilateral and commercial & 1.5 & 2.8 & 2.7 & 2.6 & 2.6 & 1.2 & 1.3 & 2.0 & 1.8 & 1.5 \\
\hline \multicolumn{11}{|l|}{ After enhanced HIPC assistance } \\
\hline Total debt service including new borrowing & 9.1 & 8.1 & 8.7 & 11.5 & 19.4 & 25.4 & 15.5 & 23.0 & 17.9 & 20.3 \\
\hline Total debt service on outstanding debt & 8.8 & 7.8 & 8.0 & 10.6 & 18.1 & 8.9 & 8.5 & 9.6 & 13.4 & 8.7 \\
\hline Multilateral & 7.9 & 7.5 & 7.7 & 10.3 & 17.7 & 8.6 & 8.1 & 9.1 & 13.0 & 8.3 \\
\hline World Bank Group & 3.5 & 3.7 & 3.9 & 4.5 & 4.8 & 5.9 & 6.6 & 7.4 & 4.9 & 6.7 \\
\hline IMF & 0.4 & 1.1 & 1.8 & 4.4 & 11.5 & 1.1 & 0.0 & 0.0 & 6.1 & 0.0 \\
\hline AfDB Group & 0.7 & 0.7 & 0.8 & 0.8 & 0.9 & 1.0 & 1.0 & 1.1 & 0.9 & 1.0 \\
\hline Others & 3.3 & 1.9 & 1.2 & 0.6 & 0.6 & 0.6 & 0.6 & 0.6 & 1.0 & 0.6 \\
\hline Official bilateral & 0.9 & 0.3 & 0.3 & 0.3 & 0.3 & 0.3 & 0.3 & 0.6 & 0.4 & 0.4 \\
\hline Paris Club & 0.8 & 0.2 & 0.2 & 0.2 & 0.2 & 0.2 & 0.2 & 0.3 & 0.2 & 0.2 \\
\hline Uther ottıcıal bılateral and commercıal & 0.1 & 0.2 & 0.2 & 0.2 & 0.2 & 0.2 & 0.2 & 0.3 & U.1 & 0.2 \\
\hline \multicolumn{11}{|l|}{ After bilateral debt relief beyond HIPC 2/ } \\
\hline Total debt service including new borrowing & 9.1 & 7.9 & 8.5 & 11.4 & 19.2 & 25.3 & 15.3 & 22.7 & 17.7 & 20.1 \\
\hline Total debt service on outstanding debt & 8.8 & 7.6 & 7.9 & 10.4 & 17.9 & 8.8 & 8.3 & 9.3 & 13.2 & 8.5 \\
\hline Multilateral & 7.9 & 7.5 & 7.7 & 10.3 & 17.7 & 8.6 & 8.1 & 9.1 & 13.0 & 8.3 \\
\hline Official bilateral & 0.9 & 0.2 & 0.2 & 0.2 & 0.2 & 0.2 & 0.2 & 0.2 & 0.2 & 0.2 \\
\hline Paris Club & 0.8 & 0.0 & 0.0 & 0.0 & 0.0 & 0.0 & 0.0 & 0.0 & 0.1 & 0.0 \\
\hline Other official bilateral and commercial & 0.1 & 0.2 & 0.2 & 0.2 & 0.2 & 0.2 & 0.2 & 0.2 & 0.1 & 0.2 \\
\hline \multicolumn{11}{|c|}{ After MDRI assistance and bilateral debt relief beyond HIPC assistance } \\
\hline Total debt service including new borrowing & 9.1 & 4.2 & 3.1 & 5.5 & 11.8 & 21.1 & 11.1 & 18.7 & 13.1 & 15.9 \\
\hline Total debt service on outstanding debt & 8.8 & 3.9 & 2.5 & 4.6 & 10.5 & 4.6 & 4.1 & 5.2 & 8.6 & 4.3 \\
\hline Multilateral & 7.9 & 3.7 & 2.4 & 4.4 & 10.3 & 4.4 & 3.9 & 5.0 & 8.3 & 4.1 \\
\hline World Bank Group & 3.5 & 1.4 & 0.7 & 1.0 & 1.4 & 2.3 & 2.9 & 3.8 & 1.9 & 3.1 \\
\hline IMF & 0.4 & 0.2 & 0.2 & 2.5 & 8.1 & 1.1 & 0.0 & 0.0 & 5.1 & 0.0 \\
\hline AfDB Group & 0.7 & 0.3 & 0.3 & 0.3 & 0.3 & 0.4 & 0.4 & 0.6 & 0.4 & 0.5 \\
\hline Others & 3.3 & 1.9 & 1.2 & 0.6 & 0.6 & 0.6 & 0.6 & 0.6 & 1.0 & 0.6 \\
\hline Official bilateral 2/ & 0.9 & 0.2 & 0.2 & 0.2 & 0.2 & 0.2 & 0.2 & 0.2 & 0.2 & 0.2 \\
\hline \multicolumn{11}{|l|}{ Memorandum items: } \\
\hline Debt service of new borrowing & 0.3 & 0.3 & 0.6 & 1.0 & 1.3 & 16.5 & 7.0 & 13.4 & 4.6 & 11.6 \\
\hline \multicolumn{11}{|l|}{ Nominal debt relief } \\
\hline Under the enhanced HIPC initiative & 36.7 & 46.0 & 51.8 & 54.7 & 54.4 & 44.2 & 45.4 & 44.5 & 48.7 & 45.1 \\
\hline Under the MDRI & 0.0 & 3.7 & 5.4 & 5.9 & 7.4 & 4.2 & 4.2 & 4.1 & 4.6 & 4.2 \\
\hline
\end{tabular}

Sources: Burundi authorities; and Bank-Fund staff estimates and projections.

1/ Assumes a stock-of-debt operation on Naples terms (67 percent NPV reduction) as of end of 2007, and at least comparable action by other official bilateral and commercial creditors.

2/ Includes additional debt relief provided on a voluntary basis by the Paris Club and some commercial creditors beyond the requirements of the enhanced HIPC framework. 
Table 13. Burundi: Key External Debt Indicators, 2007-27 1/

(In percent, unless otherwise indicated)

\begin{tabular}{|c|c|c|c|c|c|c|c|c|c|c|c|}
\hline & $\begin{array}{c}2007 \\
\text { Actual } \\
\end{array}$ & $\begin{array}{l}2008 \\
\text { Estimate } \\
\end{array}$ & 2009 & 2010 & 2011 & 2012 & 2017 & 2022 & 2027 & $2008-17$ & $2018-27$ \\
\hline \multicolumn{12}{|l|}{ After traditional debt relief } \\
\hline NPV of debt-to-GDP ratio & 87 & 75 & 63 & 57 & 54 & 49 & 32 & 20 & 13 & 49 & 20 \\
\hline NPV of debt-to-exports ratio $2 / 3 /$ & 952 & 898 & 875 & 774 & 728 & 644 & 401 & 229 & 134 & 637 & 229 \\
\hline NPV of debt-to-exports ratio (existing debt only) 2/ 3/ & 952 & 878 & 829 & 709 & 644 & 558 & 312 & 161 & 71 & 561 & 160 \\
\hline NPV of debt-to-revenues ratio $3 /$ & 469 & 391 & 326 & 295 & 278 & 254 & 156 & 97 & 63 & 250 & 96 \\
\hline Debt service-to-export ratio $3 /$ & $\ldots$ & 40 & 51 & 47 & 48 & 50 & 32 & 17 & 12 & 43 & 18 \\
\hline Debt service-to-revenue ratio $4 /$ & $\ldots$ & 21 & 20 & 20 & 20 & 21 & 13 & 8 & 6 & 18 & 8 \\
\hline \multicolumn{12}{|l|}{ After enhanced HIPC assistance } \\
\hline NPV of debt-to-GDP ratio & 89 & 79 & 16 & 16 & 16 & 16 & 12 & 9 & 8 & 21 & 9 \\
\hline NPV of debt-to-exports ratio $2 / 3 /$ & 970 & 950 & 217 & 214 & 222 & 204 & 149 & 103 & 81 & 266 & 103 \\
\hline NPV of debt-to-exports ratio (existing debt only) 2/ 3/ & 970 & 929 & 170 & 149 & 139 & 118 & 60 & 34 & 18 & 190 & 34 \\
\hline NPV of debt-to-revenues ratio $3 /$ & 478 & 413 & 81 & 82 & 85 & 81 & 58 & 44 & 38 & 107 & 44 \\
\hline Debt service-to-export ratio $3 /$ & $\ldots$ & 8 & 8 & 7 & 8 & 13 & 12 & 4 & 4 & 11 & 6 \\
\hline Debt service-to-revenue ratio 4/ & $\ldots$ & 4 & 3 & 3 & 4 & 6 & 5 & 2 & 2 & 5 & 3 \\
\hline \multicolumn{12}{|l|}{ After additional beyobd HIPC bilateral assistance } \\
\hline NPV of debt-to-GDP ratio & 89 & 78 & 15 & 15 & 16 & 15 & 12 & 9 & 8 & 21 & 9 \\
\hline NPV of debt-to-exports ratio $2 / 3 /$ & 967 & 939 & 212 & 210 & 218 & 200 & 146 & 101 & 80 & 261 & 101 \\
\hline NPV of debt-to-exports ratio (existing debt only) 2/ 3/ & 967 & 918 & 165 & 145 & 134 & 114 & 57 & 32 & 16 & 185 & 32 \\
\hline NPV of debt-to-revenues ratio $3 /$ & 477 & 408 & 79 & 80 & 83 & 79 & 57 & 43 & 37 & 106 & 43 \\
\hline Debt service-to-export ratio 3/ & $\ldots$ & 8 & 7 & 7 & 8 & 13 & 11 & 4 & 4 & 11 & 6 \\
\hline Debt service-to-revenue ratio 4/ & $\ldots$ & 4 & 3 & 3 & 3 & 5 & 5 & 2 & 2 & 5 & 3 \\
\hline \multicolumn{12}{|l|}{ After MDRI 5/ } \\
\hline NPV of debt-to-GDP ratio & 89 & 78 & 11 & 11 & 12 & 12 & 10 & 8 & 7 & 18 & 8 \\
\hline NPV of debt-to-exports ratio 2/3/ & 967 & 939 & 148 & 156 & 169 & 160 & 123 & 90 & 75 & 227 & 90 \\
\hline NPV of debt-to-exports ratio (existing debt only) 2/ 3/ & 967 & 918 & 102 & 91 & 86 & 74 & 34 & 21 & 12 & 150 & 21 \\
\hline NPV of debt-to-revenues ratio $3 /$ & 477 & 408 & 55 & 59 & 65 & 63 & 48 & 38 & 35 & 92 & 38 \\
\hline Debt service-to-export ratio 3/ & $\ldots$ & 8 & 4 & 2 & 4 & 8 & 10 & 3 & 3 & 8 & 4 \\
\hline Debt service-to-revenue ratio 4/ & $\ldots$ & 4 & 2 & 1 & 2 & 3 & 4 & 1 & 2 & 3 & 2 \\
\hline Memorandum items: & \multicolumn{11}{|c|}{ (in millions of U.S. dollars) } \\
\hline NPV of debt after traditional debt relief & 853 & 872 & 889 & 901 & 908 & 892 & 814 & 748 & 700 & 867 & 744 \\
\hline Debt service after traditional debt relief & & 46 & 54 & 61 & 66 & 74 & 70 & 61 & 68 & 67 & 65 \\
\hline NPV of debt after HIPC assistance & 869 & 921 & 220 & 249 & 277 & 283 & 301 & 335 & 423 & 342 & 350 \\
\hline Debt service after HIPC assistance & $\cdots$ & 9 & 8 & 9 & 12 & 19 & 25 & 16 & 23 & 18 & 20 \\
\hline NPV of debt after additional bilateral relief & 866 & 911 & 215 & 244 & 272 & 277 & 296 & 329 & 417 & 336 & 343 \\
\hline Debt service after additional bilateral relief & $\ldots$ & 9 & 8 & 8 & 11 & 19 & 25 & 15 & 23 & 18 & 20 \\
\hline NPV of debt after MDRI and additional bilateral relief 5/ & 866 & 911 & 150 & 181 & 211 & 221 & 250 & 292 & 393 & 287 & 309 \\
\hline Debt service after MDRI and additional bilateral relief $5 /$ & $\ldots$ & 9 & 4 & 3 & 6 & 12 & 21 & 11 & 19 & 13 & 16 \\
\hline GDP & 975 & 1,170 & 1,416 & 1,593 & 1,694 & 1,808 & 2,554 & 3,705 & 5,320 & 1,881 & 3,922 \\
\hline Exports of goods and services $3 /$ & 84 & 114 & 107 & 128 & 139 & 148 & 220 & 360 & 570 & 158 & 389 \\
\hline Exports of goods and services (3-year mvg. avg.) 2/3/ & 90 & 97 & 102 & 116 & 125 & 139 & 203 & 326 & 523 & 145 & 355 \\
\hline Government revenue 4/ & 182 & 223 & 273 & 305 & 327 & 351 & 523 & 769 & 1,111 & 371 & 815 \\
\hline
\end{tabular}

Sources: Burundi authorities; and Bank-Fund staff estimates and projections.

1/ All debt indicators refer to public and publicly guaranteed (PPG) debt and are defined after rescheduling, unless otherwise indicated.

2/ Based on a three-year average of exports on the previous year (e.g., export average over 2005-07 for NPV of debt-to-exports ratio in 2007).

3/ As defined in IMF, Balance of Payments Manual, 5th edition, 1993.

4/ Revenues are defined as central government revenues, excluding grants.

5/ Assumes delivery of MDRI relief by IDA, IMF and AfDB Group. 
Table 14. Burundi: Sensitivity Analysis, 2008-27 1/ (In percent, unless otherwise indicated)

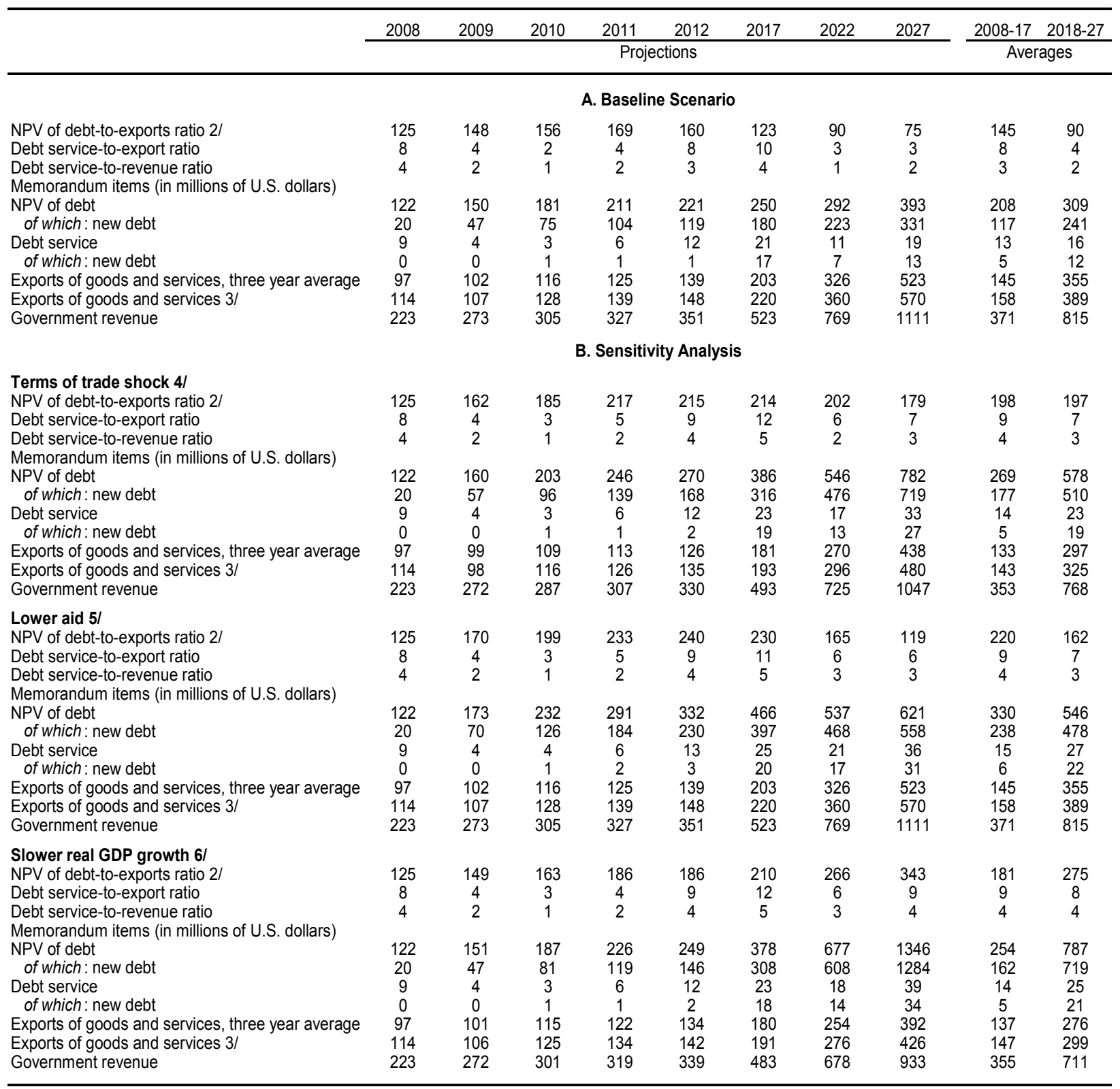

Sources: Burundi authorities; and Bank-Fund staff estimates and projections.

$1 /$ All debt indicators refer to public and publicly guaranteed debt after full delivery of debt relief (including debt relief beyond the HIPC Initiative and MDRI relief).

2/ Based on a three-year backward looking moving average of exports of goods and services.

3/ Exports of goods and services as defined in IMF, Balance of Payments Manual, 5th edition, 1993.

$4 /$ This scenario assumes a permanent decline in the export price of coffee by 20 percent and a simultaneous permanent increase in the import price of oil by 17 percent (each corresponding to the average price deviation during the past 20 years).

5/ This scenario assumes a 25 percent reduction in grants during 2009-2015.

6/ This scenario assumes a permanent reduction in real GDP growth by one percentage point. 
Table 15. Burundi: Delivery of IMF Assistance Under the Enhanced HIPC Initiative and MDRI, 2005-15 $1 /$

(In millions of SDRs, unless otherwise indicated)

\begin{tabular}{|c|c|c|c|c|c|c|c|c|c|c|c|c|}
\hline & $\begin{array}{r}2005 \\
\text { Aug-Dec }\end{array}$ & 2006 & 2007 & 2008 & $\begin{array}{r}2009 \\
\text { Jan }\end{array}$ & Feb-Dec & 2010 & 2011 & 2012 & 2013 & 2014 & 2015 \\
\hline \multicolumn{13}{|l|}{ 1. Pre-MDRI Debt relief (under the HIPC Initiative only) 2 I } \\
\hline HIPC-eligible debt service due on IMF obligations $3 /$ & 0.1 & 0.2 & 0.2 & 0.2 & - & 2.8 & 6.1 & 6.8 & 6.8 & 6.7 & 4.1 & 0.7 \\
\hline Principal & - & - & - & - & - & 2.6 & 6.0 & 6.7 & 6.7 & 6.7 & 4.1 & 0.7 \\
\hline \multicolumn{13}{|l|}{ HIPC assistance-deposits into the HIPC Umbrella Account } \\
\hline Interim assistance & 0.1 & 0.1 & 0.1 & & & & & & & & & \\
\hline Completion point disbursement & & & & & 21.9 & & & & & & & \\
\hline Completion point assistance 4/ & & & & & 19.0 & & & & & & & \\
\hline Completion point interest & & & & & 2.8 & & & & & & & \\
\hline HIPC assistance-drawdown from the HIPC Umbrella Account & 0.04 & 0.09 & 0.09 & 0.04 & - & 2.2 & 5.1 & 5.6 & 4.6 & 4.2 & 2.5 & 0.5 \\
\hline IMF assistance without interest & 0.04 & 0.1 & 0.1 & 0.04 & - & 1.5 & 3.4 & 3.8 & 3.8 & 3.8 & 2.3 & 0.4 \\
\hline Estimated interest earnings $5 /$ & - & 0.0 & 0.0 & 0.0 & - & 0.7 & 1.7 & 1.8 & 0.8 & 0.4 & 0.2 & 0.1 \\
\hline Debt service due on IMF obligations after HIPC assistance & 0.04 & 0.1 & 0.1 & 0.1 & - & 0.6 & 1.0 & 1.2 & 2.1 & 2.5 & 1.6 & 0.3 \\
\hline Delivery schedule of IMF assistance (in percent of the total assistance; on a flow basis) & 0.2 & 0.5 & 0.4 & 0.2 & - & 7.8 & 17.6 & 19.7 & 19.7 & 19.7 & 12.0 & 2.1 \\
\hline Share of debt service due on IMF obligations covered by HIPC assistance (in percent) & 50.0 & 52.5 & 52.7 & 25.4 & - & 80.0 & 83.3 & 82.0 & 68.4 & 62.5 & 62.0 & 64.5 \\
\hline \multicolumn{13}{|l|}{ Proportion (in percent) of each principal repayment falling due during the } \\
\hline period to be paid by HIPC assistance from the principal deposited in Umbrella account & 50.0 & 51.8 & 51.3 & 24.9 & - & 56.7 & 56.7 & 56.7 & 56.7 & 56.7 & 56.7 & 56.7 \\
\hline Projected pre-cutoff date debt at completion point $6 /$ & & & & & 26.4 & & & & & & & \\
\hline \multicolumn{13}{|l|}{ Delivery of debt relief (on stock basis): } \\
\hline from the MDRI-I Trust $7 /$ & & & & & 9.2 & & & & & & & \\
\hline from the HIPC Umbrella Account & & & & & 17.2 & & & & & & & \\
\hline Delivery of remaining HIPC assistance for post MDRI cutoff date debt (on stock basis): & & & & & 4.7 & & & & & & & \\
\hline III. Debt service due to the IMF after HIPC and MDRI debt relief 81 & 0.06 & 0.14 & 0.21 & 0.32 & - & 0.2 & 0.2 & 1.7 & 5.2 & 7.0 & 10.0 & 9.3 \\
\hline
\end{tabular}

Sources: IMF, Finance Department; and staff estimates and projections.

1/ Total IMF assistance under the enhanced HIPC Initiative is SDR 19.28 million in NPV terms calculated on the basis of data available at the decision point, excluding interest earned on Burundi's account and on committed but undisbursed amounts as described in footnote 5. IMF assistance committed at the decision point is adjusted upwards from SDR 19.262 million to SDR 19.28 million owing to data revisions.

2/ Reflects the projected delivery of HIPC assistance in the absence of MDRI decision.

3/ Data as of decision point. Interest obligations exclude net SDR charges and assessments which are not eligible for HIPC assistance.

4/ A final disbursement of SDR 19 million will be deposited into Burundi's Umbrella Account at the completion point in January 2009.

5/ Includes estimated interest earnings on: (a) amounts held in Burundi's account; and (b) up to the completion point, amounts committed but not yet disbursed. The projected interest earnings are estimated based on

assumed interest rates which are gradually increasing to 5 percent in 2013 and beyond; actual interest earnings may be higher or lower.

6/ Associated with disbursements made prior to December 31, 2004.

7/ Credit outstanding at end-2004 that has not been repaid by the member or with HIPC assistance at the completion point and is not scheduled to be repaid by HIPC assistance, as defined in the MDRI-I Trust Instrument

8/ Data prior to completion point represent actual debt service paid. Projected debt service from November 2008 are as of end-October 2008. 
Table 16. Burundi: Delivery of World Bank HIPC Assistance and MDRI, 2005-45

(In millions of U.S. dollars, unless otherwise indicated)

\begin{tabular}{|c|c|c|c|c|c|c|c|c|c|c|c|c|c|c|c|c|c|c|}
\hline & \multirow{2}{*}{2005} & \multirow{2}{*}{$\begin{array}{l}2006 \\
\text { Actual }\end{array}$} & \multirow{2}{*}{2007} & \multirow{2}{*}{2008} & \multirow{2}{*}{2009} & \multirow{2}{*}{2010} & \multirow{2}{*}{2011} & \multirow{2}{*}{2012} & \multirow{2}{*}{$\begin{array}{l}2013 \\
P r\end{array}$} & \multirow{2}{*}{$\begin{array}{l}2014 \\
\text { jection }\end{array}$} & \multirow{2}{*}{2015} & \multirow{2}{*}{2020} & \multirow{2}{*}{2025} & \multirow{2}{*}{2030} & \multirow{2}{*}{2040} & \multirow{2}{*}{2045} & \multicolumn{2}{|c|}{ Averages } \\
\hline & & & & & & & & & & & & & & & & & $\begin{array}{l}2000- \\
2020\end{array}$ & $\begin{array}{ll}2021- \\
2045\end{array}$ \\
\hline \multicolumn{19}{|l|}{ 1. Relief under the Enhanced HIPC Initiative $1 /$} \\
\hline World Bank debt service before HIPC relief & 21.54 & 22.97 & 23.41 & 26.40 & 28.14 & 29.72 & 31.71 & 32.67 & 34.51 & 34.74 & 35.41 & 35.10 & 38.12 & 24.87 & 9.07 & 0.04 & 32.56 & 20.12 \\
\hline Principal & 15.62 & 17.16 & 17.73 & 20.17 & 22.06 & 23.81 & 25.98 & 27.14 & 29.19 & 29.64 & 30.53 & 31.37 & 35.66 & 23.61 & 8.92 & 0.04 & 27.89 & 18.95 \\
\hline Interest & 5.92 & 5.81 & 5.68 & 6.23 & 6.08 & 5.91 & 5.73 & 5.53 & 5.33 & 5.11 & 4.88 & 3.73 & 2.46 & 1.26 & 0.15 & 0.00 & 4.67 & 1.17 \\
\hline World Bank debt service after HIPC relief & 13.1 & 2.3 & 2.3 & 3.5 & 3.7 & 3.9 & 4.5 & 4.8 & 5.3 & 5.6 & 6.0 & 5.9 & 7.6 & 6.0 & 9.1 & 0.0 & 5.69 & 5.60 \\
\hline World Bank assistance 2/ & 8.4 & 20.7 & 21.1 & 22.9 & 24.4 & 25.8 & 27.2 & 27.8 & 29.2 & 29.1 & 29.5 & 29.2 & 30.6 & 18.9 & 0.0 & 0.0 & 26.87 & 14.52 \\
\hline \multicolumn{19}{|l|}{ 2. Relief under the MDRI $3 /$} \\
\hline Projected stock of IDA cerdits outstanding at implementation date & & & & & 836.5 & & & & & & & & & & & & & \\
\hline $\begin{array}{l}\text { Debt stock reduction on eligible credits } 5 / \\
\text { Due to HIPC relief } 6 / \\
\text { Due to MDRI }\end{array}$ & & & & & $\begin{array}{r}743.0 \\
652.6 \\
90.4\end{array}$ & & & & & & & & & & & & & \\
\hline Remaining IDA credits after MDRI relief & & & & & 93.5 & & & & & & & & & & & & & \\
\hline IDA debt service relief under the MDRI 7 / & & & & & 2.39 & 3.27 & 3.43 & 3.49 & 3.62 & 3.61 & 3.65 & 3.63 & 3.71 & 2.23 & 4.01 & - & 3.54 & 2.27 \\
\hline Debt service due to IDA after HIPC relief and the MDRI & & & & & 1.35 & 0.65 & 1.04 & 1.35 & 1.70 & 1.99 & 2.31 & 2.27 & 3.86 & 3.75 & 5.06 & 0.04 & 2.24 & 3.33 \\
\hline \multicolumn{19}{|l|}{ Memorandum item: } \\
\hline \multicolumn{19}{|l|}{ HIPC relief } \\
\hline $\begin{array}{l}\text { Debt service to IDA covered by HIPC (in percent) } \\
\text { Debt service to IDA covered by HIPC and MDRI (in percent) }\end{array}$ & $\begin{array}{l}0.39 \\
0.39\end{array}$ & $\begin{array}{l}0.90 \\
0.90\end{array}$ & $\begin{array}{l}0.90 \\
0.90\end{array}$ & $\begin{array}{l}0.87 \\
0.87\end{array}$ & $\begin{array}{l}0.87 \\
0.95\end{array}$ & $\begin{array}{l}0.87 \\
0.98\end{array}$ & $\begin{array}{l}0.86 \\
0.97\end{array}$ & $\begin{array}{l}0.85 \\
0.96\end{array}$ & $\begin{array}{l}0.85 \\
0.95\end{array}$ & $\begin{array}{l}0.84 \\
0.94\end{array}$ & $\begin{array}{l}0.83 \\
0.93\end{array}$ & $\begin{array}{l}0.83 \\
0.94\end{array}$ & $\begin{array}{l}0.80 \\
0.90\end{array}$ & $\begin{array}{l}0.76 \\
0.85\end{array}$ & $\begin{array}{l}0.00 \\
0.44\end{array}$ & $\begin{array}{l}0.00 \\
0.00\end{array}$ & 0.82 & 0.54 \\
\hline $\begin{array}{l}\text { Interim Assistance 8/ } \\
\text { Interim relief as percent of total 8/ }\end{array}$ & $\begin{array}{r}68.51 \\
16.1 \%\end{array}$ & & & & & & & & & & & & & & & & & \\
\hline IDA debt service relief under the MDRI (in millions of SDR) 9/ & & & & & 1.57 & 2.15 & 2.25 & 2.29 & 2.38 & 2.37 & 2.40 & 2.38 & 2.43 & 1.46 & 2.63 & 0.00 & 2.32 & 1.49 \\
\hline
\end{tabular}

Source: IDA staff estimates.

1/ For the 2005-2007 period, debt service and debt relief is estimated on debt outstanding as of December 31, 2004, using end-2004 exchange rates. For the projection period, the debt service presented here is on end-2007 oustanding debt, using $2 /$ Enhanced HIPC assistance until end January 2009 as approved by the Board of IDA (IDA/R2005-0174). After January 2009, HIPC debt relief is based on revised schedule. Total HIPC debt relief amounts to US\$425.2 million in NPV terms, using end-2004 discount and exchange rates.

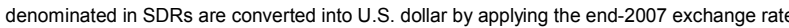

$5 /$ Debt disbursed as of end-December 2003 and still outstanding as of end-December 2007

6/ HIPC relief is assumed to proportionally reduce repayments of principal and charges on IDA credits disbursed as of end-December 2004 and still outstanding as of end-December 2007.

7/ Using end-2007 exchange rates.

9/ For SDR-denominated IDA credits, debt relief under the MDRI is estimated as 100 percent of SDR-based debt service minus USD-based debt relief under the Enhanced HIPC Initiative. HIPC debt relief is converted into SDR equivalent amounts by applying the foreign exchange reference rate of 1.52448 agreed by donors under the latest regular IDA replenishment. For USD-denominated IDA credits. Debt relief under the MDRI is estimated as 100 percent of USD-based debt service minus USD-based debt relie under the Enhanced HIPC Initiative. The resulting MDRI debt relief amounts are converted into SDR equivalent amounts by applying the foreign exchange reference rates agreed by donors under the latest regular IDA replenishment. 
Table 17. Paris Club Creditors' Delivery of Debt Relief Under Bilateral Initiatives Beyond HIPC Initiative 1/

\begin{tabular}{|c|c|c|c|c|c|c|c|}
\hline & \multirow{2}{*}{$\begin{array}{l}\text { Countries covered } \\
\text { (1) }\end{array}$} & \multicolumn{2}{|c|}{ ODA (in percent) } & \multicolumn{2}{|c|}{ Non-ODA (in percent) } & \multicolumn{2}{|c|}{ Provision of relief } \\
\hline & & Pre-cutoff date debt & Post-cutoff date debt & Pre-cutoff date debt & $\begin{array}{r}\text { Post-cutoff date debt } \\
\text { (5) }\end{array}$ & $\begin{array}{r}\text { Decision point } \\
\text { (In percent) } \\
(6) \\
\end{array}$ & $\begin{array}{r}\text { Completion } \\
\text { point } \\
(7) \\
\end{array}$ \\
\hline Australia & HIPCs & 100 & 100 & 100 & 100 & & \\
\hline Austria & HIPCs & 100 & - & 100 & - & Case-by-case, flow & Stock \\
\hline Belgium & HIPCs & 100 & 100 & 100 & - & 100 flow & Stock \\
\hline Canada & HIPCs 2I & $-3 /$ & $-3 /$ & 100 & 100 & 100 flow & Stock \\
\hline Denmark & HIPCs & 100 & $1004 /$ & 100 & $1004 /$ & 100 flow & Stock \\
\hline France & HIPCs & 100 & 100 & 100 & - & 100 flow $5 /$ & Stock \\
\hline Finland & HIPCs & 100 & $-6 /$ & 100 & $-6 /$ & - & - \\
\hline Germany & HIPCs & 100 & 100 & 100 & 100 & 100 flow & Stock \\
\hline Ireland & - & - & - & - & - & - & - \\
\hline Italy & HIPCs & 100 & $1007 /$ & 100 & $1007 /$ & 100 flow & Stock \\
\hline Japan & HIPCs & 100 & 100 & 100 & - & - & Stock \\
\hline Netherlands, the & HIPCs & $1008 /$ & 100 & 100 & - & $90-100$ flow 8/ & Stock 8/ \\
\hline Norway & HIPCs & 9/ & 9/ & $10 /$ & 10 & - & - \\
\hline Russia & HIPCS & $-11 /$ & $-11 /$ & 100 & 100 & - & Stock \\
\hline Spain & HIPCs & 100 & Case-by-case & 100 & Case-by-case & - & Stock \\
\hline Sweden & HIPCs & - & -12 & 100 & - & - & Stock \\
\hline Switzerland & HIPCs & $-13 /$ & $-13 /$ & $90-10014 /$ & - & 90-100 flow & Stock \\
\hline United Kingdom & HIPCs & 100 & 100 & 100 & 10015 & 100 flow $15 /$ & Stock \\
\hline United States & HIPCs & 100 & 100 & 100 & 10016 & 100 flow & Stock \\
\hline
\end{tabular}

Source: Paris Club Secretariat.

1/ Columns (1) to (7) describe the additional debt relief provided following a specific methodology under bilateral initiatives and need to be read as a whole for each creditor In column (1), "HIPCs" stands for eligible countries effectively qualifying for the HIPC process. A "100 percent" mention in the table indicates that the debt relief provided under the enhanced HIPC Initiative framework will be topped up to 100 percent through a bilateral initiative.

2/ Canada: including Bangladesh. Canada has granted a moratorium of debt service as of January 2001 on all debt disbursed before end-March 1999 for 13 out of 17 HIPCs with debt service due to Canada. Eligible countries are Benin, Bolivia, Cameroon, Dem. Rep. Of Congo, Ethiopia, Ghana, Guyana, Honduras, Madagascar, Rwanda, Senegal, Tanzania, and Zambia. 100\% cancellation will be granted at completion point. As of July 2004, Canada has provided completion point stock of debt cancellation for Benin, Bolivia, Guyana, Senegal and Tanzania.

3/ 100 percent of ODA claims have already been cancelled on HIPCs, with the exception of Myanmar's debt to Canada.

4/ Denmark provides 100 percent cancellation of ODA loans and non-ODA credits contracted and disbursed before September 27, 1999.

5/ France: cancellation of 100 percent of debt service on pre-cutoff date commercial claims on the government as they fall due starting at the decision point. Once countries have reached their completion point, debt relief on ODA claims on the government will go to a special account and will be used for specific development projects. 6/ Finland: no post-COD claims.

$7 /$ Italy: cancellation of 100 percent of all debts (pre- and post-cutoff date, ODA and non-ODA) incurred before June 20, 1999 (the Cologne Summit). At decision point, cancellation of the related amounts falling due in the interim period. At completion point, cancellation of the stock of remaining debt.

8/ The Netherlands: 100 percent ODA (pre- and post-cutoff date debt will be cancelled at decision point); for non-ODA: in some particular cases (Benin, Bolivia,

Burkina Faso, Ethiopia, Ghana, Mali, Mozambique, Nicaragua, Rwanda, Tanzania, Uganda and Zambia), the Netherlands will write off 100 percent of the consolidated amounts on the flow at decision point; all other HIPCs will receive interim relief up to 90 percent reduction of the consolidated amounts. At completion point, all HIPCs will receive 100 per cent cancellation of the remaining stock of the pre-cutoff date debt.

9/ Norway has cancelled all ODA claims.

10/ Due to the current World Bank/IMF methodology for recalculating debt reduction needs at HIPC completion point, Norway has postponed the decisions on whether or not to grant $100 \%$ debt reduction until after the completion point.

11/ Russia has no ODA claims

12/ Sweden has no ODA claims.

13/ Switzerland has cancelled all ODA claims.

14/ In some particular cases (Central African Republic, Liberia, Republic of Congo, Sierra Leone, Togo), Switzerland will write off 100 percent of the remaining debt stock at completion point; all other HIPCs will receive debt relief according to Paris Club terms.

15/ United Kingdom: "beyond 100 percent" full write-off of all debts of HIPCs as of their decision points, and reimbursement at the decision point of any debt service paid before the decision point.

16/ United States: 100 percent post-cutoff date non-ODA treated on debt assumed prior to June 20, 1999 (the Cologne Summit). 
Table 18. HIPC Initiative: Status of Country Cases Considered Under the Initiative (March 18, 2008)

\begin{tabular}{|c|c|c|c|c|c|c|c|c|c|c|c|}
\hline \multirow{3}{*}{ Country } & \multirow{3}{*}{$\begin{array}{r}\text { Decision } \\
\text { Point }\end{array}$} & \multirow{3}{*}{$\begin{array}{r}\text { Completion } \\
\text { Point }\end{array}$} & \multirow{3}{*}{\multicolumn{2}{|c|}{$\begin{array}{c}\text { Target } \\
\text { NPV of Debt-to- } \\
\begin{array}{r}\text { Gov. } \\
\text { Exports revenue }\end{array} \\
\text { (in percent) } \\
\end{array}$}} & \multicolumn{5}{|c|}{$\begin{array}{c}\text { Assistance Levels 1/ } \\
\text { (In millions of U.S. dollars, present value) }\end{array}$} & \multirow{3}{*}{$\begin{array}{r}\text { Percentage } \\
\text { Reduction } \\
\text { in NPV of } \\
\text { Debt 2/ } \\
\end{array}$} & \multirow{3}{*}{$\begin{array}{l}\text { Estimated Total } \\
\text { Nominal Debt } \\
\text { Service Relief } \\
\text { f (In millions of } \\
\text { U.S. dollars) }\end{array}$} \\
\hline & & & & & \multicolumn{5}{|c|}{ Bilateral and $\quad$ Multilateral } & & \\
\hline & & & & & Total & commercial & Total & IMF & World Bank & & \\
\hline \multicolumn{12}{|c|}{ Completion point reached under enhanced framework (23) } \\
\hline Benin & Jul. 00 & Mar. 03 & 150 & & 265 & 77 & 189 & 24 & 84 & 31 & 460 \\
\hline Bolivia & & & & & 1,302 & 425 & 876 & 84 & 194 & & 2,060 \\
\hline original framework & Sep. 97 & Sep. 98 & 225 & & 448 & 157 & 291 & 29 & 54 & 14 & 760 \\
\hline enhanced framework & Feb. 00 & Jun. 01 & 150 & & 854 & 268 & 585 & 55 & 140 & 30 & 1,300 \\
\hline Burkina Faso & & & & & 553 & 83 & 469 & 57 & 231 & & 930 \\
\hline original framework & Sep. 97 & Jul. 00 & 205 & & 229 & 32 & 196 & 22 & 91 & 27 & 400 \\
\hline enhanced framework & Jul. 00 & Apr. 02 & 150 & & 195 & 35 & 161 & 22 & 79 & 30 & 300 \\
\hline topping-up & $\ldots$ & Apr. 02 & 150 & & 129 & 16 & 112 & 14 & 61 & 24 & 230 \\
\hline Cameroon & Oct. 00 & Apr. 06 & 150 & & 1,267 & 879 & 322 & 37 & 176 & 27 & 4,917 \\
\hline Ethiopia & & & & & 1,982 & 637 & 1,315 & 60 & 832 & & 3,275 \\
\hline enhanced framework & Nov. 01 & Apr. 04 & 150 & & 1,275 & 482 & 763 & 34 & 463 & 47 & 1,941 \\
\hline topping-up & & Apr. 04 & 150 & & 707 & 155 & 552 & 26 & 369 & 31 & 1,334 \\
\hline Gambia, The & Dec. 00 & Dec. 07 & 150 & & 67 & 17 & 49 & 2 & 22 & 27 & 112 \\
\hline Ghana & Feb. 02 & Jul. 04 & 144 & 250 & 2,186 & 1,084 & 1,102 & 112 & 781 & 56 & 3,500 \\
\hline Guyana & & & & & 591 & 223 & 367 & 75 & 68 & & 1,354 \\
\hline original framework & Dec. 97 & May 99 & 107 & 280 & 256 & 91 & 165 & 35 & 27 & 24 & 634 \\
\hline enhanced framework & Nov. 00 & Dec-03 & 150 & 250 & 335 & 132 & 202 & 40 & 41 & 40 & 719 \\
\hline Honduras & Jul. 00 & Mar-05 & 110 & 250 & 556 & 215 & 340 & 30 & 98 & 18 & 1,000 \\
\hline Madagascar & Dec. 00 & Oct-04 & 150 & & 836 & 474 & 362 & 19 & 252 & 40 & 1,900 \\
\hline Malawi & & & & & 1,057 & 171 & 886 & 45 & 622 & & 1,628 \\
\hline enhanced framework & Dec. 00 & Aug-06 & 150 & & 646 & 164 & 482 & 30 & 333 & 44 & 1,025 \\
\hline topping-up & $\ldots$ & Aug-06 & 150 & & 411 & 7 & 404 & 15 & 289 & 35 & 603 \\
\hline Mali & & & & & 539 & 169 & 370 & 59 & 185 & & 895 \\
\hline original framework & Sep. 98 & Sep. 00 & 200 & & 121 & 37 & 84 & 14 & 43 & 9 & 220 \\
\hline enhanced framework & Sep. 00 & Mar. 03 & 150 & & 417 & 132 & 285 & 45 & 143 & 29 & 675 \\
\hline Mauritania & Feb. 00 & Jun. 02 & 137 & 250 & 622 & 261 & 361 & 47 & 100 & 50 & 1,100 \\
\hline Mozambique & & & & & 2,023 & 1,270 & 753 & 143 & 443 & & 4,300 \\
\hline original framework & Apr. 98 & Jun. 99 & 200 & & 1,717 & 1,076 & 641 & 125 & 381 & 63 & 3,700 \\
\hline enhanced framework & Apr. 00 & Sep. 01 & 150 & & 306 & 194 & 112 & 18 & 62 & 27 & 600 \\
\hline Nicaragua & Dec. 00 & Jan. 04 & 150 & & 3,308 & 2,175 & 1,134 & 82 & 191 & 73 & 4,500 \\
\hline Niger & & & & & 663 & 235 & 428 & 42 & 240 & & 1,190 \\
\hline enhanced framework & Dec. 00 & Apr. 04 & 150 & & 521 & 211 & 309 & 28 & 170 & 53 & 944 \\
\hline topping-up & $\ldots$ & Apr. 04 & 150 & & 143 & 23 & 119 & 14 & 70 & 25 & 246 \\
\hline Rwanda & & & & & 696 & 65 & 631 & 63 & 383 & & 1,316 \\
\hline enhanced framework & Dec. 00 & Apr-05 & 150 & & 452 & 56 & 397 & 44 & 228 & 71 & 839 \\
\hline topping-up & $\ldots$ & Apr-05 & 150 & & 243 & 9 & 235 & 20 & 154 & 53 & 477 \\
\hline São Tomé and Príncipe & & & & & 124 & 31 & 93 & 1 & 47 & 128 & 263 \\
\hline enhanced framework & Dec. 00 & Mar-07 & 150 & & 99 & 29 & 70 & - & 24 & 83 & 215 \\
\hline topping-up & & Mar-07 & 150 & & 25 & 2 & 23 & 1 & 23 & 45 & 49 \\
\hline Senegal & Jun. 00 & Apr. 04 & 133 & 250 & 488 & 212 & 276 & 45 & 124 & 19 & 850 \\
\hline Sierra Leone & Mar. 02 & Dec. 06 & 150 & & 675 & 335 & 340 & 125 & 123 & 81 & 994 \\
\hline Tanzania & Apr. 00 & Nov. 01 & 150 & & 2,026 & 1,006 & 1,020 & 120 & 695 & 54 & 3,000 \\
\hline Uganda & & & & & 1,003 & 183 & 820 & 160 & 517 & & 1,950 \\
\hline original framework & Apr. 97 & Apr. 98 & 202 & & 347 & 73 & 274 & 69 & 160 & 20 & 650 \\
\hline enhanced framework & Feb. 00 & May 00 & 150 & & 656 & 110 & 546 & 91 & 357 & 37 & 1,300 \\
\hline Zambia & Dec. 00 & Apr-05 & 150 & & 2,499 & 1,168 & 1,331 & 602 & 493 & 63 & 3,900 \\
\hline \multicolumn{12}{|c|}{ Decision point reached under enhanced framework (11) } \\
\hline Afghanistan & Jul. 07 & Floating & 150 & & 571 & 436 & 135 & - & 75 & 51 & 1,272 \\
\hline Burundi & Aug. 05 & Floating & 150 & & 826 & 124 & 701 & 28 & 425 & 92 & 1,465 \\
\hline Central African Rep. & Sept. 07 & Floating & 150 & & 583 & 217 & 365 & 27 & 209 & 68 & 782 \\
\hline Chad & May. 01 & Floating & 150 & & 170 & 35 & 134 & 18 & 68 & 30 & 260 \\
\hline Congo, Democratic Rep. of & Jul. 03 & Floating & 150 & & 6,311 & 3,837 & 2,474 & 472 & 831 & 80 & 10,389 \\
\hline Congo Rep. of & Mar. 06 & Floating & & 250 & 1,679 & 1,561 & 118 & 8 & 49 & 32 & 2,881 \\
\hline Guinea & Dec. 00 & Floating & 150 & & 545 & 215 & 328 & 31 & 152 & 32 & 800 \\
\hline Guinea-Bissau & Dec. 00 & Floating & 150 & & 416 & 212 & 204 & 12 & 93 & 85 & 790 \\
\hline Haiti & Nov. 06 & Floating & 150 & & 140 & 20 & 120 & 3 & 53 & 15 & 213 \\
\hline Liberia & Feb.08 & Floating & 150 & & 2,846 & 1,420 & 1,426 & 732 & 375 & 91 & 4,008 \\
\hline Togo & Nov. 08 & Floating & & 250 & 270 & 120 & 150 & 0 & 98 & 19 & 88 \\
\hline \multicolumn{5}{|c|}{ Total assistance provided/committed } & 39,683 & 19,594 & 19,990 & 3,369 & 9,329 & 1,262 & 68,340 \\
\hline
\end{tabular}

Sources: IMF and World Bank Board decisions, completion point documents, decision point documents, preliminary HIPC documents, and staff calculations.

1/ Assistance levels are at countries' respective decision or completion points, as applicable.

$2 /$ In percent of the net present value of debt at the decision or completion point (as applicable), after the full use of traditional debt-relief mechanisms. 
Table 19. Burundi: Selected Economic and Financial Indicators, 2003-27 1/

\begin{tabular}{|c|c|c|c|c|c|}
\hline & 2003-07 & 2008-12 & $2013-17$ & $2018-22$ & 2023-27 \\
\hline & & \multicolumn{4}{|c|}{ Projections } \\
\hline & \multicolumn{5}{|c|}{ (Annual percentage change) } \\
\hline National income and prices & & & & & \\
\hline Real GDP growth & 2.6 & 4.8 & 5.0 & 5.0 & 5.0 \\
\hline Consumer prices (end of period) & 9.5 & 10.0 & 4.6 & 4.0 & 4.0 \\
\hline \multicolumn{6}{|l|}{ External sector } \\
\hline Exports, f.o.b. (US\$) & 12.2 & 14.4 & 5.8 & 6.9 & 6.9 \\
\hline Imports, f.o.b. (US\$) & 22.5 & 5.6 & 8.1 & 5.8 & 6.3 \\
\hline Export volume & 1.0 & 13.7 & 5.6 & 6.3 & 6.3 \\
\hline \multirow[t]{2}{*}{ Import volume } & 12.5 & 6.2 & 7.4 & 5.0 & 5.4 \\
\hline & \multicolumn{5}{|c|}{ (Percent of GDP, unless otherwise indicated) } \\
\hline \multicolumn{6}{|l|}{ General government } \\
\hline Revenue (excluding grants) & 19.7 & 19.4 & 20.2 & 20.8 & 21.0 \\
\hline Total expenditure and net lending & 37.6 & 43.1 & 35.0 & 28.1 & 27.1 \\
\hline \multicolumn{6}{|l|}{ Overall balance (commitment basis) } \\
\hline Excluding grants & -17.9 & -23.8 & -14.7 & -7.3 & -6.1 \\
\hline Including grants & -3.7 & 10.7 & -2.6 & -0.8 & -1.4 \\
\hline Savings-Investment balance & -10.5 & -12.1 & -15.5 & -12.8 & -8.9 \\
\hline Private & -8.0 & -10.0 & -12.9 & -12.0 & -7.5 \\
\hline Public & -2.5 & -2.1 & -2.6 & -0.8 & -1.4 \\
\hline \multicolumn{6}{|l|}{ External sector } \\
\hline Current account, including grants & -22.6 & -9.9 & -11.1 & -8.3 & -5.2 \\
\hline Gross official reserves (months of imports of the following year) & 3.3 & 3.3 & 3.0 & 3.0 & 3.0 \\
\hline \multicolumn{6}{|l|}{ Memorandum item: } \\
\hline GDP at current market prices (Fbu billion) & 848.5 & 1878.5 & 3136.1 & 5014.7 & 7940.3 \\
\hline
\end{tabular}

Sources: Burundi authorities; and IMF staff estimates and projections.

1/ Period averages. 


\section{APPENDIX I}

\section{BURUNDi: DebT ManAgement}

1. Since the decision point, debt management in Burundi has improved. In particular, in terms of the governance structure, the Ministry of Finance has now the exclusive right to negotiate and sign external loans. In addition, the authorities have reorganized the unit in charge of debt at the Ministry of Finance, have staffed it more adequately, and have provided it with more appropriate technical facilities.

2. The main impediment to debt management remains the lack of trained human resources at the "Direction de la Dette Extérieure" (DDE) at the Ministry of Finance, which is the unit responsible for debt management. While there has been an improvement in record-keeping at the debt management unit, additional improvements are required. In particular, there appears to be insufficient communication between the debt management and public enterprises. This limits the authorities' debt management capacity.

3. The authorities continue to benefit from training from UNCTAD and have introduced the latest version of SYGADE, a debt management software. Nevertheless, the benefits of using this debt management software are limited by the lack of trained and experienced staff. Accordingly, data for disbursements, debt service, and payment plan schedules are prone to errors.

4. For a more effective external debt management, Burundi should have wellcoordinated institutional arrangements that are fully integrated into the overall macroeconomic policymaking framework. In this regard, the DDE should coordinate better with other relevant government institutions, including the central bank.

\section{Looking forward, the authorities should continue to improve external debt}

management. Technical assistance should be maintained in order to improve the skills of the debt management unit. This will ensure accurate and timely reporting on debt outstanding, debt service projections as well as a timely execution of debt-service obligations. Once the basic back-office functions are in place, Burundi will be in a better position to articulate a sound debt management strategy based on a more informed analysis. 


\section{APPENDIX II \\ BURUNDi: DEbT SUSTAINABILITY ANALYSIS USING THE LOW-INCOME COUNTRY FRAMEWORK}

\section{This debt sustainability analysis (LIC DSA) assesses Burundi's external and public debt dynamics using the forward-looking debt sustainability framework} (DSF) for low-income countries. ${ }^{1}$ The LIC DSA is based on the reconciled debt database used for the HIPC DSA and incorporates the impact of HIPC and MDRI relief in the baseline. Three key methodological differences explain variations in the LIC DSA results from those of the HIPC DSA: (i) the discount rate is fixed at 5 percent, compared to the currency-specific 6-month average of commercial interest reference rate (CIRR) used in the HIPC DSA; (ii) the export denominator is based on the current level of exports, rather than the three-year backward average in the HIPC DSA; and (iii) exchange rate projections are used to convert the debt data after debt relief. ${ }^{2}$

\section{Despite the delivery of HIPC and MDRI assistance, Burundi has a high risk} of debt distress. Nevertheless, this is an improvement compared to the previous LIC DSA, which found Burundi to be "in debt distress". ${ }^{3}$ After full delivery of HIPC assistance, bilateral debt relief beyond the HIPC Initiative and MDRI, Burundi's present value of debt-to-exports ratio is expected to remain above the country-specific policy dependent threshold for most of the projection period. Under the standard alternative scenarios and stress tests, all indicators with the exception of the debt-to-revenue and debt service-to-revenue ratios exceed the country-specific debt burden thresholds. Given these results, Burundi should continue to rely on grants and highly concessional loans to meet its financing needs, while intensifying efforts to increase and diversify its export base.

\footnotetext{
${ }^{1}$ See "Debt Sustainability in Low-Income Countries: Proposal for an Operational Framework and Policy Implications" (http://www.imf.org/external/np/pdr/sustain/2004/020304.htm and IDA/SECM2004/0035, 2/3/04) and "Debt Sustainability in Low-Income Countries: Further Considerations on an Operational Framework and Policy Implications" (http://www.imf.org/external/np/pdr/sustain/2004/091004.htm and IDA/SECM2004/0629, 9/10/04).

${ }^{2}$ The present value of debt is calculated by discounting debt service converted in dollar terms using the WEO average exchange rate with respect to the U.S. dollar for the first 5 years of the projection period, and maintaining the exchange rates constant thereafter. This differs from the HIPC methodology, where the present value of debt is calculated by applying currency specific discount rates to debt service converted into dollar at fixed end-2007 exchange rates. See "Staff Guidance Note on the Application of the Joint BankFund Debt Sustainability Framework for Low-Income Countries” October 6, 2008.

${ }^{3}$ This appendix updates the DSA prepared in December 2007 (IMF Country Report No. 08/27, January 23, 2008).
} 


\section{Four key differences underpin the results of this LIC DSA relative to the} previous one: (i) debt relief is based on the calculations of the HIPC completion point rather than on earlier preliminary estimates; (ii) real GDP growth is assumed to be lower by about 1 percentage point, closer to the historical average; (iii) the baseline scenario assumes lower growth of exports and imports of goods and services, partly stemming from lower WEO prices for primary commodities and oil respectively; and (iv) nominal GDP is higher due to the spike in inflation as a result of higher food and oil prices in 2007 and the first half of 2008 .

\section{RECENT DEVELOPMENTS}

\section{Burundi's public and publicly guaranteed (PPG) external debt decreased} slightly in 2007. Nominal PPG debt amounted to US\$1.5 billion or 155 percent of GDP in 2007 while the present value (PV) of debt-to-exports ratio stood at 104.8 percent. About 86 percent of Burundi's outstanding external PPG debt was owed to multilateral creditors, with bilateral creditors accounting for the remainder. External debt service in 2007 was reduced to 6.8 percent of exports in 2007 from 10.7 percent in 2006 ,

\begin{tabular}{|c|c|c|c|c|c|c|}
\hline \multicolumn{7}{|c|}{ Table 1. Burundi: Public External Debt, 2004-07 } \\
\hline & \multicolumn{2}{|c|}{2004} & \multicolumn{2}{|c|}{2006} & \multicolumn{2}{|c|}{2007} \\
\hline & $\begin{array}{c}\text { U.S. } \\
\text { Dollars }\end{array}$ & $\begin{array}{c}\text { Percent of } \\
\text { Total }\end{array}$ & $\begin{array}{l}\text { U.S. } \\
\text { Dollars }\end{array}$ & $\begin{array}{c}\text { Percent of } \\
\text { Total }\end{array}$ & $\begin{array}{l}\text { U.S. } \\
\text { Dollars }\end{array}$ & $\begin{array}{l}\text { Percent of } \\
\text { Total }\end{array}$ \\
\hline Total & 1,384 & 100.0 & 1,472 & 100.0 & $1,468.0$ & 100.0 \\
\hline Multilateral & 1170 & 84.5 & 1253 & 85.1 & 1,262 & 86.0 \\
\hline Bilateral & 208 & 15.0 & 213 & 14.5 & 205.4 & 14.0 \\
\hline Paris Club & 145.1 & 10.5 & 146.3 & 9.9 & 152.1 & 10.4 \\
\hline Non-Paris Club & 62.5 & 4.5 & 67.0 & 4.6 & 53.3 & 3.6 \\
\hline Commercial & 6.6 & 0.5 & 5.8 & 0.4 & 0.6 & 0.0 \\
\hline
\end{tabular}
reflecting primarily debt relief by Paris Club creditors.

\section{Key ASSUMPTIONS}

\section{The baseline macroeconomic outlook has been updated to reflect recent}

developments (Box 1). The near term outlook will be influenced by the adverse impact of the international financial crisis. Provided the security situation continues to improve, Burundi's medium and long-term outlook is broadly positive. Real GDP growth is expected to average 5 percent over the long term, sustained by the consolidation of peace, maintenance of macroeconomic stability, continued improvements in the business environment, and greater openness to trade, following Burundi's accession to the East African Community (EAC). Investment is expected to average about 16 percent of GDP, a level considered to be supportive of economic growth. Exports of goods and services are assumed to drive growth over the long term, following investments in key export sectors over the medium term (traditional and non-traditional). The external current account deficit, including grants, will decline over time, despite lower donor support. Financing 
will continue to be in the form of grants and highly concessional loans. Fiscal policy would be supportive of economic growth and poverty reduction, while preserving debt sustainability. Revenue mobilization efforts would lead to a gradual increase in government revenues, while expenditure would gradually decline to more sustainable levels, once the current transition phase ends.

6. Risks to the macroeconomic outlook are significant. A worsening of the political, social and security situation would endanger donor support and lead to a rapid deterioration of debt indicators. Exogenous shocks, including a stronger-than-expected impact of the international economic crisis on exports and growth and a reversal of the current downward trend in oil prices, would lead to a further deterioration in debt indicators.

\section{EXTERnAl DebT Sustainability AnALysis}

7. All but one debt indicators are expected to remain below the country-specific debt burden thresholds under the baseline scenario. Following HIPC and MDRI relief, the present value (PV) of debt-to-GDP, the PV of debt-to-revenues, the debt service-to exports ratio, and the debt service-to revenue ratios are expected to remain well below the indicative country-specific thresholds throughout the projection period (Box 2 and Table 1). ${ }^{4}$ All debt and debt-service indicators increase modestly over the medium term and then gradually level off. In contrast, the PV of debt-to-exports ratio will remain above the 100 percent threshold until 2019 and then decline rapidly to about 70 percent at the end of the projection period. The evolution of the present value of debt-to-exports ratio reflects the country's development needs over the medium term and the gradual improvement in export capacity.

\footnotetext{
${ }^{4}$ The latest World Bank Country Policy and Institutional Assessment (CPIA) rates Burundi as a poor performer. The three-year moving average CPIA in 2007 is 3.0. This score has remained unchanged during the last three years. A rating below 3.25 corresponds to a poor policy performance, according to the LIC DSF.
} 


\section{Box 1: Main Macroeconomic Assumptions, 2008-28}

Real GDP growth is expected to accelerate to 5 percent over the medium term reflecting the consolidation of peace, the reform of the coffee sector, and economic stimulus from increased capital spending associated with donor support. Long-term growth is expected to be about 5 percent. Investment is expected to average about 16 percent of GDP, a level considered to be supportive of long-term economic growth.

Inflation is assumed to decline gradually over the medium term and stabilize at about 4 percent over the long term, as the central bank moves to strengthen its policy instruments.

Fiscal policy would be supportive of economic growth and poverty reduction, while maintaining debt sustainability and macroeconomic stability.

- Government revenues, excluding grants, are projected to remain rather stable over the medium term, but gradually increase to about 21 percent of GDP over the long term. This increase reflects primarily a widening of the tax base as a result of continued tax administration reforms.

- Government expenditure is expected to gradually decline over time to the more sustainable level of about 27 percent of GDP. This path is consistent with a gradual reduction of current spending growth, and higher pro-poor spending. Public investment is expected to gradually decline over time to about 4 percent of GDP as the private sector becomes the engine of growth.

Exports of goods and services are projected to increase by an average of 7 percent over the medium term reflecting in part lower commodity prices; they are projected to increase by 9-10 percent over the longer term as investment in key export sectors (traditional and nontraditional) begins to yield results. In volume terms, exports of goods are projected to gradually increase.

Imports of goods and services will gradually decelerate over time to a more sustainable rate of 5 percent. With emergency and reconstruction-related imports winding down and oil prices declining over the medium term, merchandise import volumes in the outer years are expected to move broadly in line with real GDP growth.

Current account deficit, including grants, is expected to deteriorate to about 17 percent of GDP in 2015, and then gradually decline to about 9 percent at the end of the projection period. Excluding transfers, the current account deficit is assumed to decline from 26 percent of GDP to about 9 percent at the end of the projection period. The authorities will rely largely on highly concessional loans to finance the current account deficit.

External financing will increasingly rely on loans in the long term, as grants gradually subside. Grant support is assumed to decline from about 26 percent of GDP in 2008 to about 10 percent in 2015 as humanitarian assistance gradually declines. Loans are assumed to gradually decline from about 3 percent of GDP in 2008 to about 1 percent at the end of the projection period. Borrowing is assumed to take place primarily on highly concessional terms. 


\begin{tabular}{|lrrrrr|}
\hline \multicolumn{7}{|c|}{ Box 2. Burundi: Summary of Baseline Debt Sustainability Indicators } \\
(Percent) \\
\end{tabular}

8. Alternative scenarios and stress tests underscore the underlying risks. Under the historical scenario, debt indicators are considerably worse over the medium term, but improve rapidly relative to the baseline scenario. The results of the historical scenario should be interpreted with caution, given Burundi's history of conflict. The scenario assuming new borrowing at a higher interest rate shows that debt indicators at the end of the projection period are generally worse than in the baseline scenario. This result underscores the need for continued reliance on grants and highly concessional financing, especially since the grace period and maturity under the alternative scenario are identical to the baseline scenario. Burundi is also vulnerable to a variety of shocks, most notably to a combination of growth, export, inflation, and FDI/current transfers shock. The bound tests suggest that in the presence of shocks, all debt indicators, with the exception of the debt service to revenue ratio will exceed the indicative debt-burden thresholds.

\section{The risk of debt distress will remain high following the HIPC completion}

point. The preceding analysis suggests that there is a protracted breach of the present value of debt-to-exports threshold under the baseline scenario, while alternative scenarios and bound tests suggest that all debt burden thresholds are likely to be exceeded in the event of shocks. 


\section{FISCAL DEBT SUSTAINABILITY}

10. Public debt indicators are expected to gradually improve under the baseline scenario. Public external debt accounts for almost the entire stock of public debt. ${ }^{5}$ The ratios of the present value of public debt-to-GDP and public debt-to-revenues are low reflecting Burundi's reliance on grants to finance the reconstruction and poverty reduction efforts. They are expected to decline over time as the public sector borrowing requirement declines reflecting the improvement in the revenue base and the gradual decline in government spending in the post-reconstruction period.

11. The alternative scenarios and stress tests show that public debt indicators can worsen rapidly. All debt indicators worsen assuming an unchanged primary balance from 2008, highlighting the need for fiscal prudence over time. A scenario based on the historical growth and primary balance also leads to a rapid deterioration of debt indicators, thus underscoring the importance of avoiding past unsustainable policies. Under the most extreme shock, which assumes lower real GDP growth and higher primary deficit, all debt indicators worsen rapidly. Nevertheless, the debt service-to-revenue ratio increases only gradually, as additional borrowing is on highly concessional terms.

\section{CONCLUSION}

\section{Burundi will remain at a high risk of debt distress following the HIPC} completion point and debt relief under MDRI. Despite the positive impact of debt relief, the PV of external debt-to-exports will remain above the country-specific debt burden threshold over the long term. Burundi is also vulnerable to exogenous shocks which could lead to a considerable worsening of debt indicators. Burundi should therefore continue to implement prudent policies that support macroeconomic stability. In particular, it should continue to rely on grants and highly concessional loans to meet its financing needs, while intensifying efforts to improve tax administration and widen the tax base. Finally, it should diversify the export base and encourage private sector development by addressing existing weaknesses in the business environment.

\footnotetext{
${ }^{5}$ The baseline scenario assumes no issuance of medium-term domestic debt, as the market for government debt is not expected to play a significant role in meeting the government's financing needs in the foreseeable future.
} 
Table 1: External Debt Sustainability Framework, Baseline Scenario, 2005-2028 1/

(In percent of GDP, unless otherwise indicated)

\begin{tabular}{|c|c|c|c|c|c|c|c|c|c|c|c|c|c|c|c|}
\hline & \multicolumn{3}{|c|}{ Actual } & \multirow{2}{*}{$\begin{array}{l}\text { Historical } \\
\text { Average }\end{array}$} & \multirow{2}{*}{$\begin{array}{l}\text { Standard } \\
\text { Deviation }\end{array}$} & \multicolumn{6}{|c|}{ Projections } & \multirow[b]{2}{*}{$2008-2013$} & \multirow[b]{2}{*}{2018} & \multirow[b]{2}{*}{2028} & \multirow[b]{2}{*}{$\begin{array}{c}\text { 2014-202 } \\
\text { Average }\end{array}$} \\
\hline & 2005 & 2006 & 2007 & & & 2008 & 2009 & 2010 & 2011 & 2012 & 2013 & & & & \\
\hline External debt (nominal) $1 /$ & 169.8 & 154.8 & 148.8 & & & 122.0 & 26.3 & 27.0 & 27.3 & 26.9 & 26.5 & & 22.7 & 16.0 & \\
\hline o/w public and publicly guaranteed (PPG) & 169.8 & 154.8 & 148.8 & & & 122.0 & 26.3 & 27.0 & 27.3 & 26.9 & 26.5 & & 22.7 & 16.0 & \\
\hline Change in external debt & -52.0 & -15.0 & -6.0 & & & -26.8 & -95.6 & 0.7 & 0.3 & -0.3 & -0.4 & & -1.4 & -0.5 & \\
\hline Identified net debt-creating flows & -39.8 & -11.2 & -1.2 & & & -1.7 & -1.9 & 0.0 & 1.9 & 3.4 & 4.2 & & 9.2 & 5.8 & \\
\hline Non-interest current account deficit & -1.1 & 14.3 & 15.3 & 6.0 & 5.5 & 12.9 & 11.4 & 10.0 & 120 & 13.6 & 14.4 & 124 & 14.4 & 7.8 & 118 \\
\hline Deficit in balance of goods and services & 29.1 & 38.5 & 39.8 & & & 36.7 & 28.6 & 26.2 & 26.1 & 25.7 & 252 & & 21.3 & 127 & \\
\hline Exports & 11.5 & 10.1 & 8.6 & & & 98 & 76 & 81 & 82 & 82 & 8.3 & & 87 & 10.8 & \\
\hline Imports & 40.6 & 48.6 & 48.3 & & & 46.5 & 36.2 & 34.3 & 34.4 & 33.9 & 33.5 & & 30.1 & 23.5 & \\
\hline Net current transfers (negative $=$ inflow) & -30.1 & -24.9 & -24.6 & -15.2 & 9.5 & -24.1 & -17.5 & -16.6 & -14.5 & -12.5 & -11.2 & & -7.1 & -6.2 & -7.0 \\
\hline o/w official & -27.9 & -21.8 & -21.6 & & & -20.9 & -14.3 & -13.5 & -11.5 & -9.6 & -8.3 & & -5.5 & -4.7 & \\
\hline Other current account flows (negative $=$ net inflow) & -0.1 & 0.8 & 0.2 & & & 0.3 & 0.3 & 0.3 & 0.3 & 0.4 & 0.3 & & 0.2 & 1.2 & \\
\hline Net FDI (negative $=$ inflow) & -3.4 & -3.8 & -8.1 & -4.0 & 2.5 & -9.0 & -9.0 & -8.9 & -8.9 & -9.0 & -9.1 & & -4.2 & -1.3 & -3.4 \\
\hline Endogenous debt dynamics 21 & -35.4 & -21.7 & -8.5 & & & -5.6 & -4.4 & -1.0 & -1.1 & -1.1 & -1.1 & & -1.0 & -0.7 & \\
\hline Contribution from nominal interest rate & 2.3 & 0.2 & 0.4 & & & 0.0 & 0.1 & 0.1 & 0.1 & 0.2 & 0.2 & & 0.2 & 0.1 & \\
\hline Contribution from real GDP growth & -1.7 & -7.6 & -5.2 & & & -5.6 & -4.5 & -1.2 & -1.3 & -1.3 & -1.3 & & -1.1 & -0.8 & \\
\hline Contribution from price and exchange rate changes & -36.0 & -14.3 & -3.6 & & & & & & & & & & & & \\
\hline Residual (3-4) 3/ & -12.2 & -3.9 & -4.8 & & & -25.1 & -93.7 & 0.6 & -1.6 & -3.8 & -4.6 & & -10.5 & -6.3 & \\
\hline $\mathrm{o} / \mathrm{w}$ exceptional financing & -4.9 & -4.3 & -5.9 & & & -7.8 & -84.3 & 0.0 & 0.0 & 0.0 & 0.0 & & 0.0 & 0.0 & \\
\hline $\mathrm{PV}$ of external debt $4 /$ & & & 9.0 & & & 9.4 & 9.9 & 11.0 & 12.3 & 12.2 & 12.1 & & 9.9 & 7.4 & \\
\hline In percent of expo & & & 104.8 & & & 96.2 & 131.7 & 136.3 & & 149.0 & 146.1 & & 113.4 & 68.5 & \\
\hline PV of PPG external debt & $\ldots$ & $\ldots$ & 9.0 & & & 9.4 & 9.9 & 11.0 & 12.3 & 12.2 & 12.1 & & 9.9 & 7.4 & \\
\hline In percent of exports & $\ldots$ & $\ldots$ & 104.8 & & & 96.2 & 131.7 & 136.3 & 149.7 & 149.0 & 146.1 & & 113.4 & 68.5 & \\
\hline In percent of government revenues & & & 48.2 & & & 49.3 & 51.6 & 56.5 & 63.1 & 62.4 & 61.0 & & 47.9 & 35.3 & \\
\hline Debt service-to-exports ratio (in percent) & 28.4 & 10.7 & 6.8 & & & 3.0 & 3.7 & 2.4 & 4.0 & 7.9 & 8.8 & & 8.7 & 4.2 & \\
\hline PPG debt service-to-exports ratio (in percent) & 28.4 & 10.7 & 6.8 & & & 3.0 & 3.7 & 2.4 & 4.0 & 7.9 & 8.8 & & 8.7 & 4.2 & \\
\hline PPG debt service-to-revenue ratio (in percent) & 16.3 & 5.7 & 3.1 & & & 1.5 & 1.4 & 1.0 & 1.7 & 3.3 & 3.7 & & 3.7 & 2.2 & \\
\hline Total gross financing need (Millions of U.S. dollars) & -9.5 & 106.8 & 76.3 & & & 48.8 & 38.8 & 20.4 & 56.8 & 94.3 & 115.8 & & 301.0 & 396.5 & \\
\hline Non-interest current account deficit that stabilizes debt ratio & 50.9 & 29.4 & 21.4 & & & 39.7 & 107.1 & 9.4 & 11.7 & 13.9 & 14.8 & & 15.8 & 8.2 & \\
\hline \multicolumn{16}{|l|}{ Key macroeconomic assumptions } \\
\hline Real GDP growth (in percent) & 0.9 & 5.1 & 3.6 & 2.3 & 2.6 & 4.5 & 4.5 & 5.0 & 5.0 & 5.0 & 5.0 & 4.8 & 5.0 & 5.0 & 5.0 \\
\hline GDP deflator in US dollar terms (change in percent) & 19.4 & 9.2 & 2.4 & -1.7 & 10.6 & 14.8 & 15.8 & 7.2 & 1.3 & 1.7 & 1.7 & 7.1 & 2.7 & 2.4 & 2.4 \\
\hline Effective interest rate (percent) 5/ & 1.3 & 0.1 & 0.3 & 0.8 & 0.6 & 0.0 & 0.1 & 0.5 & 0.6 & 0.6 & 0.6 & 0.4 & 0.7 & 0.7 & 0.7 \\
\hline Growth of exports of G\&S (US dollar terms, in percent) & 44.8 & 1.0 & -10.2 & 1.0 & 24.0 & 36.8 & -6.5 & 20.0 & 8.4 & 6.7 & 7.6 & 12.1 & 9.5 & 8.8 & 9.5 \\
\hline Growth of imports of G\&S (US dollar terms, in percent) & 44.2 & 37.5 & 5.5 & 15.6 & 21.7 & 15.3 & -5.7 & 6.6 & 6.6 & 5.5 & 5.4 & 5.6 & 5.0 & 4.9 & 5.0 \\
\hline Grant element of new public sector borrowing (i & & & & & & 52.5 & 48.7 & 48.6 & 48.5 & 58.8 & 58.8 & 52.6 & 58.8 & 58.8 & 58.8 \\
\hline Government revenues (excluding grants, in percent of GDP) & 20.0 & 18.9 & 18.6 & & & 19.1 & 19.3 & 19.4 & 19.5 & 19.6 & 19.8 & & 20.7 & 21.0 & 20.8 \\
\hline Aid flows (in Millions of US dollars) $7 /$ & 163.1 & 198.5 & 227.6 & & & 337.9 & 1224.5 & 363.5 & 344.1 & 334.9 & 352.7 & & 251.8 & 297.0 & \\
\hline o/w Gran & 93.8 & 164.2 & 203.7 & & & 298.5 & 1185.5 & 324.9 & 305.9 & 300.5 & 316.0 & & 224.2 & 239.8 & \\
\hline $\mathrm{o} / \mathrm{w}$ Concessional loans & 69.3 & 34.3 & 24.0 & & & 39.4 & 39.0 & 38.6 & 38.2 & 34.4 & 36.7 & & 27.6 & 57.2 & \\
\hline Grant-equivalent financing (in percent of GDP) $8 /$ & $\ldots$ & $\cdots$ & $\ldots$ & & & 27.8 & 85.8 & 22.2 & 19.7 & 17.7 & 17.5 & & 8.7 & 4.8 & 7.5 \\
\hline Grant-equivalent financing (in percent of external financing) $8 /$ & & & & & & 93.2 & 97.6 & 92.1 & 91.8 & 95.8 & 95.7 & & 95.5 & 92.1 & 93.5 \\
\hline \multicolumn{16}{|c|}{0} \\
\hline illions of US dollars) & 800.6 & 919.0 & 974.7 & & & 1169.7 & 1415.8 & 1592.5 & 1694.3 & 1808.2 & 1930.7 & & 2754.7 & 5718.0 & \\
\hline Nominal dollar GDP growth & 20.5 & 14.8 & 6.1 & & & 20.0 & 21.0 & 12.5 & 6.4 & 6.7 & 6.8 & 12.2 & 7.8 & 7.5 & 7.5 \\
\hline PV of PPG external debt (in Millions of US dollars) & & & 87.6 & & & 110.0 & 140.7 & 174.8 & 208.1 & 220.9 & 233.1 & & 273.3 & 424.6 & \\
\hline (PVt-PVt-1)/GDPt-1 (in percent) & & & & & & 2.3 & 2.6 & 2.4 & 2.1 & 0.8 & 0.7 & 1.8 & 0.2 & 0.3 & 0.4 \\
\hline
\end{tabular}

Source: Staff simulations

$1 /$ Includes both public and private sector external debt.

(ithe previous period debt ratio, with $r=$ nominal interest rate; $g=$ real GDP growth rate, and $r=$ growth rate of GDP deflator in U.S. dollar terms. Assumes that PV of private sector debt is equivalent to its face value.

$5 /$ Current-year interest payments divided by previous period debt stock.

$6 /$ Historical averages and standard deviations are generally derived over the past 10 years, subject to data availability. 
Table 2a.Burundi: Sensitivity Analysis for Key Indicators of Public and Publicly Guaranteed External Debt, 2008-2028

(In percent)

\begin{tabular}{|c|c|c|c|c|c|c|c|c|c|c|c|c|c|c|c|c|c|c|c|c|c|}
\hline & \multicolumn{21}{|c|}{$\begin{array}{cc} & \text { Projections } \\
\end{array}$} \\
\hline & 2008 & 2009 & 2010 & 2011 & 2012 & 2013 & 2014 & 2015 & 2016 & 2017 & 2018 & 2019 & 2020 & 2021 & 2022 & 2023 & 2024 & 2025 & 2026 & 2027 & 2028 \\
\hline & \multicolumn{21}{|c|}{ PV of debt-to GDP ratio } \\
\hline Baseline & 9 & 10 & 11 & 12 & 12 & 12 & 12 & 11 & 11 & 11 & 10 & 9 & 9 & 9 & 9 & 8 & 8 & 8 & 8 & 8 & 7 \\
\hline \multicolumn{22}{|l|}{ A. Alternative Scenarios } \\
\hline A1. Key variables at their historical averages in 2008-2028 1/ & 9 & 18 & 21 & 23 & 23 & 23 & 20 & 17 & 13 & 10 & 6 & 1 & & & & & & & & & \\
\hline A2. New public sector loans on less favorable terms in $2008-202821$ & 9 & 10 & 11 & 12 & 12 & 12 & 12 & 11 & 11 & 11 & 11 & 10 & 10 & 10 & 10 & 10 & 9 & 9 & 9 & 9 & 9 \\
\hline \multicolumn{22}{|l|}{ B. Bound Tests } \\
\hline B1. Real GDP growth at historical average minus one standard deviation in 2009-2010 & 9 & 10 & 12 & 14 & 13 & 13 & 13 & 13 & 12 & 12 & 11 & 10 & 10 & 10 & 9 & 9 & 9 & 9 & 9 & 8 & 8 \\
\hline B2. Export value growth at historical average minus one standard deviation in 2009-2010 3/ & 9 & 11 & 13 & 14 & 14 & 14 & 14 & 13 & 13 & 12 & 12 & 11 & 11 & 10 & 10 & 10 & 9 & 9 & 9 & 8 & 8 \\
\hline B3. US dollar GDP deflator at historical average minus one standard deviation in 2009-2010 & 9 & 13 & 18 & 20 & 20 & 19 & 19 & 18 & 18 & 17 & 16 & 15 & 15 & 14 & 14 & 14 & 13 & 13 & 13 & 12 & 12 \\
\hline B4. Net non-debt creating flows at historical average minus one standard deviation in 2009-2010 4/ & 9 & 18 & 27 & 28 & 27 & 27 & 26 & 25 & 24 & 24 & 23 & 21 & 20 & 19 & 18 & 17 & 16 & 15 & 14 & 13 & 13 \\
\hline B5. Combination of B1-B4 using one-half standard deviation shocks & 9 & 22 & 40 & 42 & 41 & 40 & 39 & 38 & 37 & 36 & 34 & 32 & 30 & 28 & 27 & 25 & 24 & 23 & 22 & 20 & 19 \\
\hline B6. One-time 30 percent nominal depreciation relative to the baseline in $20095 /$ & 9 & 13 & 15 & 17 & 16 & 16 & 16 & 15 & 15 & 14 & 13 & 13 & 12 & 12 & 12 & 11 & 11 & 11 & 11 & 10 & 10 \\
\hline & \multicolumn{21}{|c|}{ PV of debt-to-exports ratio } \\
\hline Baseline & 96 & 132 & 136 & 150 & 149 & 146 & 141 & 134 & 128 & 122 & 113 & 105 & 98 & 93 & 88 & 84 & 81 & 78 & 74 & 71 & 69 \\
\hline \multicolumn{22}{|l|}{ A. Alternative Scenarios } \\
\hline A1. Key variables at their historical averages in 2008-2028 1/ & 96 & 244 & 265 & 286 & 283 & 273 & 245 & 201 & 155 & 111 & 64 & 14 & & & & & & & & & \\
\hline A2. New public sector loans on less favorable terms in 2008-2028 21 & 96 & 131 & 134 & 146 & 146 & 144 & 140 & 136 & 132 & 131 & 124 & 117 & 111 & 105 & 100 & 96 & 92 & 89 & 86 & 83 & 80 \\
\hline \multicolumn{22}{|l|}{ B. Bound Tests } \\
\hline B1. Real GDP growth at historical average minus one standard deviation in 2009-2010 & 96 & 132 & 136 & 150 & 149 & 146 & 141 & 134 & 128 & 122 & 113 & 105 & 98 & 93 & 88 & 84 & 81 & 78 & 74 & 71 & 68 \\
\hline B2. Export value growth at historic & 96 & 169 & 310 & 333 & 330 & 323 & 312 & 297 & 283 & 272 & 253 & 234 & 217 & 204 & 192 & 181 & 173 & 165 & 157 & 149 & 142 \\
\hline B3. US dollar GDP deflator at historical average minus one standard deviation in 2009-2010 & 96 & 132 & 136 & 150 & 149 & 146 & 141 & 134 & 128 & 122 & 113 & 105 & 98 & 93 & 88 & 84 & 81 & 78 & 74 & 71 & 68 \\
\hline B4. Net non-debt creating flows at historical average minus on & 96 & 244 & 333 & 339 & 334 & 325 & 313 & 300 & 287 & 275 & 258 & 239 & 218 & 199 & 183 & 168 & 156 & 145 & 135 & 126 & 117 \\
\hline B5. Combination of B1-B4 u & 96 & 240 & 461 & 469 & 462 & 450 & 434 & 415 & 397 & 380 & 358 & 331 & 302 & 276 & 254 & 233 & 217 & 202 & 188 & 175 & 164 \\
\hline B6. One-time 30 percent nominal depreciation relative to the baseline in $20095 /$ & 96 & 132 & 136 & 150 & 149 & 146 & 141 & 134 & 128 & 122 & 113 & 105 & 98 & 93 & 88 & 84 & 81 & 78 & 74 & 71 & 68 \\
\hline & \multicolumn{21}{|c|}{ PV of debt-to-revenue ratio } \\
\hline Baseline & 49 & 52 & 56 & 63 & 62 & 61 & 59 & 56 & 53 & 51 & 48 & 45 & 43 & 42 & 41 & 40 & 39 & 38 & 37 & 36 & 35 \\
\hline \multicolumn{22}{|l|}{ A. Alternative Scenarios } \\
\hline A1. Key variables at their historical averages in 2008-2028 $1 /$ & 49 & 96 & 110 & 120 & 119 & 114 & 102 & 84 & 65 & 46 & 27 & 6 & & & & & & & & $\cdots$ & $\ldots$ \\
\hline A2. New public sector loans on less favorable terms in 2008-2028 2/ & 49 & 51 & 56 & 61 & 61 & 60 & 59 & 57 & 55 & 55 & 52 & 50 & 49 & 48 & 47 & 46 & 45 & 44 & 43 & 42 & 41 \\
\hline \multicolumn{22}{|l|}{ B. Bound Tests } \\
\hline B1. Real GDP growth at historical average & 49 & 54 & 62 & 70 & 69 & 67 & 65 & 62 & 59 & 57 & 53 & 50 & 48 & 46 & 45 & 44 & 43 & 42 & 41 & 40 & 39 \\
\hline B2. Export value growth at historical average minus one standard deviatio & 49 & 55 & 68 & 74 & 73 & 71 & 69 & 65 & 62 & 60 & 56 & 53 & 51 & 49 & 47 & 46 & 44 & 43 & 42 & 40 & 39 \\
\hline B3. US dollar GDP deflator at historical average minus one standard deviation in 2009-2010 & 49 & 68 & 91 & 102 & 101 & 98 & 95 & 90 & 86 & 83 & 77 & 73 & 70 & 68 & 66 & 65 & 63 & 62 & 60 & 59 & 57 \\
\hline B4. Net non-debt creating flows at historical average minus one standard deviation in 2009-2010 4/ & 49 & 96 & 138 & 143 & 140 & 136 & 131 & 125 & 120 & 115 & 109 & 103 & 96 & 90 & 85 & 80 & 76 & 72 & 68 & 64 & 60 \\
\hline B5. Combination of B1-B4 using one-half standard deviation shocks & 49 & 115 & 208 & 216 & 211 & 205 & 197 & 189 & 180 & 173 & 165 & 155 & 145 & 136 & 129 & 122 & 115 & 109 & 103 & 97 & 92 \\
\hline B6. One-time 30 percent nominal depreciation relative to the baseline in & 49 & 70 & 76 & 85 & 84 & 82 & 79 & 75 & 72 & 69 & 65 & 61 & 58 & 57 & 55 & 54 & 53 & 52 & 50 & 49 & 48 \\
\hline
\end{tabular}


Table 2b.Burundi: Sensitivity Analysis for Key Indicators of Public and Publicly Guaranteed External Debt, 2008-2028

(In percent)

\begin{tabular}{|c|c|c|c|c|c|c|c|c|c|c|c|c|c|c|c|c|c|c|c|c|c|}
\hline & \multicolumn{21}{|c|}{ Projections } \\
\hline & 2008 & 2009 & 2010 & 2011 & 2012 & 2013 & 2014 & 2015 & 2016 & 2017 & 2018 & 2019 & 2020 & 2021 & 2022 & 2023 & 2024 & 2025 & 2026 & 2027 & 2028 \\
\hline & \multicolumn{21}{|c|}{ Debt service-to-exports ratio } \\
\hline Baseline & 3 & 4 & 2 & 4 & 8 & 9 & 11 & 12 & 11 & 10 & 9 & 8 & 6 & 5 & 4 & 4 & 4 & 4 & 4 & 4 & 4 \\
\hline \multicolumn{22}{|l|}{ A. Alternative Scenarios } \\
\hline A1. Key variables at their historical averages in 2008-2028 $1 /$ & 3 & 6 & 5 & 7 & 13 & 15 & 19 & 21 & 21 & 19 & 17 & 20 & 17 & 13 & 9 & 8 & 7 & 5 & 3 & 1 & 0 \\
\hline A2. New public sector loans on less favorable terms in 2008-2028 21 & 3 & 5 & 3 & 5 & 10 & 11 & 12 & 12 & 10 & 7 & 6 & 6 & 6 & 5 & 5 & 5 & 5 & 5 & 5 & 5 & 5 \\
\hline \multicolumn{22}{|l|}{ B. Bound Tests } \\
\hline B1. Real GDP growth at historical average minus one standard deviation in 2009-2010 & 3 & 5 & 2 & 4 & 8 & 9 & 11 & 12 & 11 & 10 & 9 & 8 & 6 & 5 & 4 & 4 & 4 & 4 & 4 & 4 & 4 \\
\hline B2. Export value growth at historical average minus one standard deviation in 2009-2010 $3 /$ & 3 & 6 & 5 & 8 & 16 & 17 & 21 & 23 & 22 & 19 & 17 & 15 & 14 & 11 & 9 & 9 & 9 & 9 & 9 & 9 & 9 \\
\hline B3. US dollar GDP defflator at historical average minus one standard deviation in 2009-2010 & 3 & 5 & 2 & 4 & 8 & 9 & 11 & 12 & 11 & 10 & 9 & 8 & 6 & 5 & 4 & 4 & 4 & 4 & 4 & 4 & 4 \\
\hline B4. Net non-debt creating flows at historical average minus one standard deviation in 2009-2010 $4 /$ & 3 & 5 & 4 & 7 & 11 & 12 & 13 & 14 & 14 & 12 & 11 & 13 & 14 & 12 & 10 & 10 & 9 & 9 & 9 & 8 & 8 \\
\hline B5. Combination of B1-B4 using one-half standard deviation shocks & 3 & 5 & 5 & 10 & 15 & 16 & 19 & 20 & 19 & 17 & 15 & 18 & 20 & 17 & 14 & 14 & 13 & 13 & 12 & 12 & 11 \\
\hline B6. One-time 30 percent nominal depreciation relative to the baseline in $20095 /$ & 3 & 5 & 2 & 4 & 8 & 9 & 11 & 12 & 11 & 10 & 9 & 8 & 6 & 5 & 4 & 4 & 4 & 4 & 4 & 4 & 4 \\
\hline & \multicolumn{21}{|c|}{ Debt service-to-revenue ratio } \\
\hline Baseline & 2 & 1 & 1 & 2 & 3 & 4 & 4 & 5 & 5 & 4 & 4 & 3 & 3 & 2 & 2 & 2 & 2 & 2 & 2 & 2 & 2 \\
\hline \multicolumn{22}{|l|}{ A. Alternative Scenarios } \\
\hline A1. Key variables at their historical averages in 2008-2028 1/ & 2 & 2 & 2 & 3 & 5 & 6 & 8 & 9 & 9 & 8 & 7 & 9 & 7 & 6 & 4 & 4 & 3 & 2 & 1 & 0 & 0 \\
\hline A2. New public sector loans on less favorable terms in 2008-2028 21 & 2 & 2 & 1 & 2 & 4 & 5 & 5 & 5 & 4 & 3 & 3 & 3 & 2 & 2 & 2 & 2 & 2 & 2 & 2 & 2 & 2 \\
\hline \multicolumn{22}{|l|}{ B. Bound Tests } \\
\hline B1. Real GDP growth at historical average minus one standard deviation in 2009-2010 & 2 & 2 & 1 & 2 & 4 & 4 & 5 & 5 & 5 & 5 & 4 & 4 & 3 & 2 & 2 & 2 & 2 & 2 & 2 & 2 & 2 \\
\hline B2. Export value growth at historical average minus one standard deviation in 2009-2010 & 2 & 2 & 1 & 2 & 3 & 4 & 5 & 5 & 5 & 4 & 4 & 3 & 3 & 3 & 2 & 2 & 2 & 2 & 2 & 2 & 2 \\
\hline B3. US dollar GDP deflator at historical average minus one standard deviation in 2009-2010 & 2 & 2 & 2 & 3 & 5 & 6 & 7 & 8 & 8 & 7 & 6 & 5 & 4 & 3 & 3 & 3 & 3 & 3 & 3 & 3 & 3 \\
\hline B4. Net non-debt creating flows at historical average minus one standard deviation in 2009-2010 $4 /$ & 2 & 2 & 2 & 3 & 5 & 5 & 6 & 6 & 6 & 5 & 4 & 6 & 6 & 6 & 5 & 5 & 5 & 4 & 4 & 4 & 4 \\
\hline B5. Combination of B1-B4 using one-half standard deviation shocks & 2 & 2 & 2 & 5 & 7 & 7 & 8 & 9 & 9 & 8 & 7 & 8 & 9 & 8 & 7 & 7 & 7 & 7 & 7 & 6 & 6 \\
\hline B6. One-time 30 percent nominal depreciation relative to the baseline in $20095 /$ & 2 & 2 & 1 & 2 & 4 & 5 & 6 & 7 & 6 & 6 & 5 & 4 & 4 & 3 & 2 & 2 & 3 & 3 & 3 & 3 & 3 \\
\hline \multicolumn{22}{|l|}{ Memorandum item: } \\
\hline Grant element assumed on residual financing (i.e., financing required above baseline) $6 /$ & 56 & 56 & 56 & 56 & 56 & 56 & 56 & 56 & 56 & 56 & 56 & 56 & 56 & 56 & 56 & 56 & 56 & 56 & 56 & 56 & 56 \\
\hline
\end{tabular}

Sources: Staff projections and simulations.

1/Variables include real GDP growth, growth of GDP deflator (in U.S. dollar terms), non-interest current account in percent of GDP, and non-debt creating flows.

2/ Assumes that the interest rate on new borrowing is by 2 percentage points higher than in the baseline., while grace and maturity periods are the same as in the baseline.

3/ Exports values are assumed to remain permanently at the lower level, but the current account as a share of GDP is assumed to return to its baseline level after the shock (implicitly assuming

an offsetting adjustment in import levels).

4/IIncludes official and private transfers and FDl.

6/ Applies to all stress scenarios except for A2 (less favorable financing) in which the terms on all new financing are as specified in footnote 2

CInternational Monetary Fund. Not for Redistribution 
Table 3.Burundi: Public Sector Debt Sustainability Framework, Baseline Scenario, 2005-2028 (In percent of GDP, unless otherwise indicated)

\begin{tabular}{|c|c|c|c|c|c|c|c|c|c|c|c|c|c|c|c|}
\hline & \multicolumn{3}{|c|}{ Actual } & \multirow[b]{2}{*}{ Average } & \multirow[b]{2}{*}{$\begin{array}{l}\text { Standard } \\
\text { Deviation }\end{array}$} & \multicolumn{4}{|l|}{ Estimate } & \multicolumn{2}{|c|}{ Projections } & \multirow[b]{2}{*}{$\begin{array}{l}2008-13 \\
\text { Average }\end{array}$} & \multirow[b]{2}{*}{2018} & \multirow[b]{2}{*}{2028} & \multirow[b]{2}{*}{$\begin{array}{l}2014-28 \\
\text { Average }\end{array}$} \\
\hline & 2005 & 2006 & 2007 & & & 2008 & 2009 & 2010 & 2011 & 2012 & 2013 & & & & \\
\hline $\begin{array}{l}\text { Public sector debt } 1 / \\
\text { o/w foreign-currency denominated }\end{array}$ & $\begin{array}{l}169.8 \\
169.8\end{array}$ & $\begin{array}{l}154.8 \\
154.8\end{array}$ & $\begin{array}{l}148.8 \\
148.8\end{array}$ & & & $\begin{array}{l}122.0 \\
122.0\end{array}$ & $\begin{array}{l}26.3 \\
26.3\end{array}$ & $\begin{array}{l}27.0 \\
27.0\end{array}$ & $\begin{array}{l}27.3 \\
27.3\end{array}$ & $\begin{array}{l}26.9 \\
26.9\end{array}$ & $\begin{array}{l}26.5 \\
26.5\end{array}$ & & $\begin{array}{l}22.7 \\
22.7\end{array}$ & $\begin{array}{l}16.0 \\
16.0\end{array}$ & \\
\hline $\begin{array}{l}\text { Change in public sector debt } \\
\text { Identified debt-creating flows }\end{array}$ & $\begin{array}{l}-52.0 \\
-48.6\end{array}$ & $\begin{array}{l}-15.0 \\
-16.1\end{array}$ & $\begin{array}{l}-6.0 \\
-2.7\end{array}$ & & & $\begin{array}{l}-26.8 \\
-29.7\end{array}$ & $\begin{array}{l}-95.7 \\
-80.6\end{array}$ & $\begin{array}{l}0.7 \\
1.8\end{array}$ & $\begin{array}{l}0.3 \\
2.5\end{array}$ & $\begin{array}{r}-0.4 \\
3.2\end{array}$ & $\begin{array}{r}-0.4 \\
3.0\end{array}$ & & $\begin{array}{l}-1.4 \\
-2.5\end{array}$ & $\begin{array}{r}-0.5 \\
0.4\end{array}$ & \\
\hline Primary deficit & 0.5 & -0.1 & -3.2 & 0.7 & 2.2 & -1.4 & -59.7 & 2.7 & 3.5 & 4.3 & 4.3 & -7.7 & -0.9 & 1.5 & 1.4 \\
\hline Revenue and grants & 31.7 & 36.8 & 39.5 & & & 44.6 & 103.0 & 39.8 & 37.5 & 36.2 & 36.2 & & 28.9 & 25.2 & \\
\hline of which: grants & 11.7 & 17.9 & 20.9 & & & 25.5 & 83.7 & 20.4 & 18.1 & 16.6 & 16.4 & & 8.1 & 4.2 & \\
\hline $\begin{array}{l}\text { Automatic debt dynamics } \\
\text { Anture }\end{array}$ & -47.9 & -13.0 & $\begin{array}{r}0.4 \\
1.6\end{array}$ & & & -28.3 & -20.9 & -0.9 & -1.0 & -1.1 & -1.3 & & -1.5 & -1.0 & \\
\hline Contribution from interest rate/growth differential & -4.0 & -11.8 & -7.2 & & & -7.8 & -6.0 & -0.9 & -1.1 & -1.2 & -1.3 & & -1.4 & -1.0 & \\
\hline of which: contribution from average real inte & -2.0 & -3.5 & -1.8 & & & -1.3 & -0.8 & 0.4 & 0.2 & 0.1 & 0.0 & & -0.2 & -0.2 & \\
\hline of which: contribution from real GDP growth & -2.0 & $\begin{array}{lll}-0.5 \\
-8.3\end{array}$ & $\begin{array}{l}-1.0 \\
-5.3\end{array}$ & & & -1.04 & -5.2 & -1.2 & -1.3 & -1.3 & -1.3 & & -1.2 & -0.8 & \\
\hline Contribution from real exchange rate depreciation & -43.9 & -1.2 & 8.8 & & & -20.5 & -14.8 & 0.0 & 0.0 & 0.1 & 0.1 & & & & \\
\hline Other identified debt-creating flows & -1.1 & -3.0 & -1.2 & & & 0.0 & 0.0 & 0.0 & 0.0 & 0.0 & 0.0 & & 0.0 & 0.0 & \\
\hline Privatization receipts (negative) & -0.3 & -1.1 & -0.8 & & & 0.0 & 0.0 & 0.0 & 0.0 & 0.0 & 0.0 & & 0.0 & 0.0 & \\
\hline Recognition of implicit or contingent liabilities & 0.0 & 0.0 & 0.0 & & & 0.0 & 0.0 & 0.0 & 0.0 & 0.0 & 0.0 & & 0.0 & 0.0 & \\
\hline Debt relief (HIPC and other) & -0.8 & -1.9 & -0.3 & & & 0.0 & 0.0 & 0.0 & 0.0 & 0.0 & 0.0 & & 0.0 & 0.0 & \\
\hline Other (specify, e.g. bank recapit & 0.0 & 0.0 & 0.0 & & & 0.0 & 0.0 & 0.0 & 0.0 & 0.0 & 0.0 & & 0.0 & 0.0 & \\
\hline Residual, including asset changes & -3.5 & 1.1 & -3.3 & & & 2.9 & -15.0 & -1.2 & -2.2 & -3.6 & -3.4 & & 1.1 & -0.9 & \\
\hline \multicolumn{16}{|l|}{ Other Sustainability Indicators } \\
\hline PV of public sector debt & 0.0 & 0.0 & 9.3 & & & 9.3 & 9.7 & 11.3 & 12.5 & 12.4 & 12.2 & & 10.0 & 7.5 & \\
\hline PV of contingent liabilities (not included in public sector debt) & & & & & & & & & & & & & & & \\
\hline Gross financing need 21 & $\begin{array}{l}7.1 \\
0.0\end{array}$ & $\begin{array}{l}4.7 \\
0.0\end{array}$ & $\begin{array}{c}-1.7 \\
23.4\end{array}$ & & & $\begin{array}{r}-0.8 \\
20.8\end{array}$ & 0.5 & $\begin{array}{r}-58.8 \\
28.3\end{array}$ & $\begin{array}{r}4.2 \\
33.4\end{array}$ & $\begin{array}{r}4.7 \\
34.3\end{array}$ & $\begin{array}{r}5.7 \\
33.9\end{array}$ & & $\begin{array}{r}1.8 \\
34.7\end{array}$ & 1.7 & \\
\hline $\begin{array}{l}\text { PV of public sector debt-to-revenue and grants ratio (in percent) } \\
\text { PV of public sector debt-to-revenue ratio (in percent) }\end{array}$ & $\begin{array}{l}0.0 \\
0.0\end{array}$ & $\begin{array}{l}0.0 \\
0.1\end{array}$ & $\begin{array}{l}23.4 \\
49.7\end{array}$ & & & $\begin{array}{l}20.8 \\
48.8\end{array}$ & $\begin{array}{r}9.4 \\
50.5\end{array}$ & $\begin{array}{l}28.3 \\
58.0\end{array}$ & $\begin{array}{ll}33.4 \\
64.3\end{array}$ & $\begin{array}{ll}34.3 \\
63.5\end{array}$ & $\begin{array}{l}33.9 \\
61.9\end{array}$ & & $\begin{array}{l}34.7 \\
48.3\end{array}$ & ${ }_{35.6}^{29.7}$ & \\
\hline $\begin{array}{l}\mathrm{PV} \text { of public sector debt-to-revenue ratio (in percent) } \\
\text { o/w external } 3 /\end{array}$ & & & 49.6 & & & 48.7 & 50.4 & 57.9 & 64.3 & 63.5 & 61.9 & & 48.3 & 35.6 & \\
\hline Debt service-to-revenue and grants ratio (in percent) $4 /$ & 12.1 & -4.1 & 6.0 & & & 4.2 & 2.2 & 4.0 & 3.5 & 4.1 & 4.2 & & 3.7 & 1.8 & \\
\hline Debt service-to-revenue ratio ( & 22.8 & 8.0 & 11.3 & & & 8.4 & 7.2 & 4.5 & 3.8 & 3.3 & 2.5 & & 1.0 & 0.5 & \\
\hline 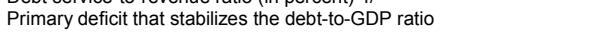 & 52.5 & 14.9 & 2.9 & & & 25.4 & 35.9 & 2.0 & 3.2 & 4.7 & 4.7 & & 0.4 & 1.9 & \\
\hline \multicolumn{16}{|l|}{ iscal assumptions } \\
\hline Real GDP growth (in percent) & 0.9 & 5.1 & 3.6 & 2.3 & 2.6 & 4.5 & 4.5 & 5.0 & 5.0 & 5.0 & 5.0 & 4.8 & 5.0 & 5.0 & 5.0 \\
\hline Average nominal interest rate on forex debt (in percent) & 1.3 & 0.1 & 0.3 & 0.8 & 0.6 & 0.0 & 0.1 & 0.5 & 0.6 & 0.6 & 0.6 & 0.4 & 0.7 & 0.7 & 0.7 \\
\hline Real exchange rate depreciation (in percent, + indicates depreciation) & -22.2 & -5.0 & 12.0 & 12.2 & 22.4 & -7.5 & & & & & & & & & \\
\hline Inflation rate (GDP deflator, in percent) & 19.4 & 9.2 & 2.4 & -1.7 & 10.6 & 14.8 & 15.8 & 7.2 & 1.3 & 1.7 & 1.7 & 7.1 & 2.7 & 2.4 & 2.4 \\
\hline Growth of real primary spending (deflated by GDP deflator, in percent) & -4.2 & 19.7 & 2.8 & 2.4 & 7.3 & 24.0 & 4.7 & 3.2 & 1.3 & 3.7 & 4.7 & 6.9 & -5.1 & 5.1 & 2.2 \\
\hline Grant element of new external borrowing (in percent) & & & $\ldots$ & & 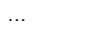 & 52.5 & 48.7 & 48.6 & 48.5 & 58.8 & 58.8 & 52.6 & 58.8 & 58.8 & \\
\hline
\end{tabular}

Sources: Burundi authorities; and Fund staff estimates and projections.

Sources: Burundi authorities; and Fund staff estimales and projections.
1/ Central government on a gross basis.

2/ Gross financing need is defined as the primary deficit plus debse

$4 /$ Debt service is defined as the sum of interest and amortization of medium and long-term debt. 
Table 4. Burundi: Sensitivity Analysis for Key Indicators of Public Debt 2008-2028

PV of Debt-to-GDP Ratio
Baseline
A. Alternative scenarios
A1. Real GDP growth and primary balance are at historical averages
A2. Primary balance is unchanged from 2008
A3. Permanently lower GDP growth 1/
B. Bound tests
B1. Real GDP growth is at historical average minus one standard deviations in 2009-2010
B2. Primary balance is at historical average minus one standard deviations in 2009-2010
B3. Combination of B1-B2 using one half standard deviation shocks
B4. One-time 30 percent real depreciation in 2009
B5. 10 percent of GDP increase in other debt-creating flows in 2009

\begin{tabular}{llllllll}
\hline \multicolumn{7}{c}{ Projections } \\
2008 & 2009 & 2010 & 2011 & 2012 & 2013 & 2018 & 2028 \\
\hline
\end{tabular}

Baseline

$\begin{array}{rrrrrrrr}9 & 10 & 11 & 13 & 12 & 12 & 10 & 7 \\ & & & & & & & \\ 9 & 39 & 40 & 40 & 39 & 37 & 32 & 20 \\ 9 & 39 & 36 & 35 & 31 & 28 & 17 & \ldots \\ 9 & 39 & 12 & 13 & 13 & 13 & 13 & 18 \\ & & & & & & & \\ & & & & & & & \\ 9 & 11 & 14 & 16 & 17 & 18 & 19 & 23 \\ 9 & 39 & 40 & 41 & 40 & 39 & 33 & 20 \\ 9 & 40 & 42 & 43 & 43 & 43 & 40 & 31 \\ 9 & 45 & 43 & 41 & 38 & 35 & 23 & 12 \\ 9 & 14 & 16 & 17 & 17 & 17 & 14 & 9\end{array}$

PV of Debt-to-Revenue Ratio 2/

Baseline

21

$\begin{array}{lllllll}9 & 28 & 33 & 34 & 34 & 35 & 30\end{array}$

A. Alternative scenarios

A1. Real GDP growth and primary balance are at historical averages

A2. Primary balance is unchanged from 2008

A3. Permanently lower GDP growth $1 /$

\section{B. Bound tests}

B1. Real GDP growth is at historical average minus one standard deviations in 2009-2010

B2. Primary balance is at historical average minus one standard deviations in 2009-2010

B3. Combination of B1-B2 using one half standard deviation shocks

B4. One-time 30 percent real depreciation in 2009

B5. 10 percent of GDP increase in other debt-creating flows in 2009

Debt Service-to-Revenue Ratio 2/

Baseline

\section{A. Alternative scenarios}

A1. Real GDP growth and primary balance are at historical averages

A2. Primary balance is unchanged from 2008

A3. Permanently lower GDP growth 1/

$\begin{array}{rrrrrrrr}21 & 37 & 98 & 104 & 102 & 97 & 104 & 71 \\ 21 & 38 & 91 & 92 & 87 & 77 & 58 & \ldots \\ 21 & 38 & 29 & 34 & 36 & 36 & 45 & 71 \\ & & & & & & & \\ & & & & & & & \\ 21 & 10 & 33 & 41 & 45 & 47 & 65 & 88 \\ 21 & 38 & 101 & 109 & 111 & 108 & 115 & 78 \\ 21 & 38 & 102 & 112 & 116 & 115 & 136 & 120 \\ 21 & 44 & 107 & 109 & 105 & 97 & 80 & 49 \\ 21 & 14 & 40 & 45 & 46 & 46 & 48 & 37\end{array}$

\section{B. Bound tests}

B1. Real GDP growth is at historical average minus one standard deviations in 2009-2010

B2. Primary balance is at historical average minus one standard deviations in 2009-2010

B3. Combination of B1-B2 using one half standard deviation shocks

B4. One-time 30 percent real depreciation in 2009

B5. 10 percent of GDP increase in other debt-creating flows in 2009

$\begin{array}{lllllllll}4 & 2 & 4 & 4 & 4 & 4 & 4 & 2\end{array}$

Sources: Burundi authorities; and Fund staff estimates and projections

$1 /$ Assumes that real GDP growth is at baseline minus one standard deviation divided by the length of the projection period.

2/ Revenues are defined inclusive of grants. 
Figure 1. Burundi: Indicators of Public and Publicly Guaranteed External Debt under Alternatives Scenarios, 2008-2028 1/
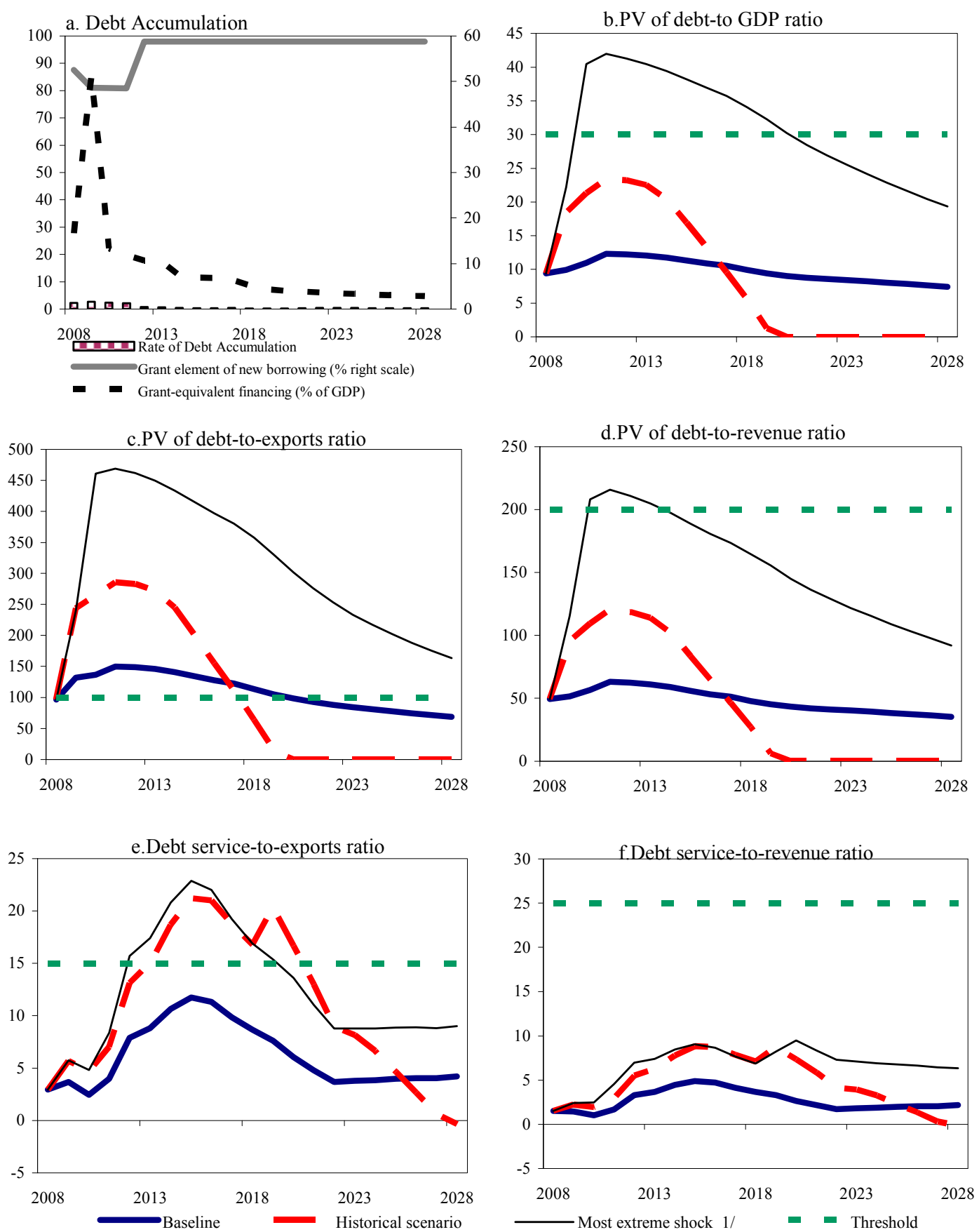

Sources: Staff projections and simulations.

1/ The most extreme stress test is the test that yields the highest ratio in 2018. In figure b. it corresponds to a Combination shock; in c. to a Combination shock; in d. to a Combination shock; in e. to a Exports shock and in picture f. to a Combination shock. 
Figure 2.Burundi: Indicators of Public Debt Under Alternative Scenarios, 2008-2028 1/

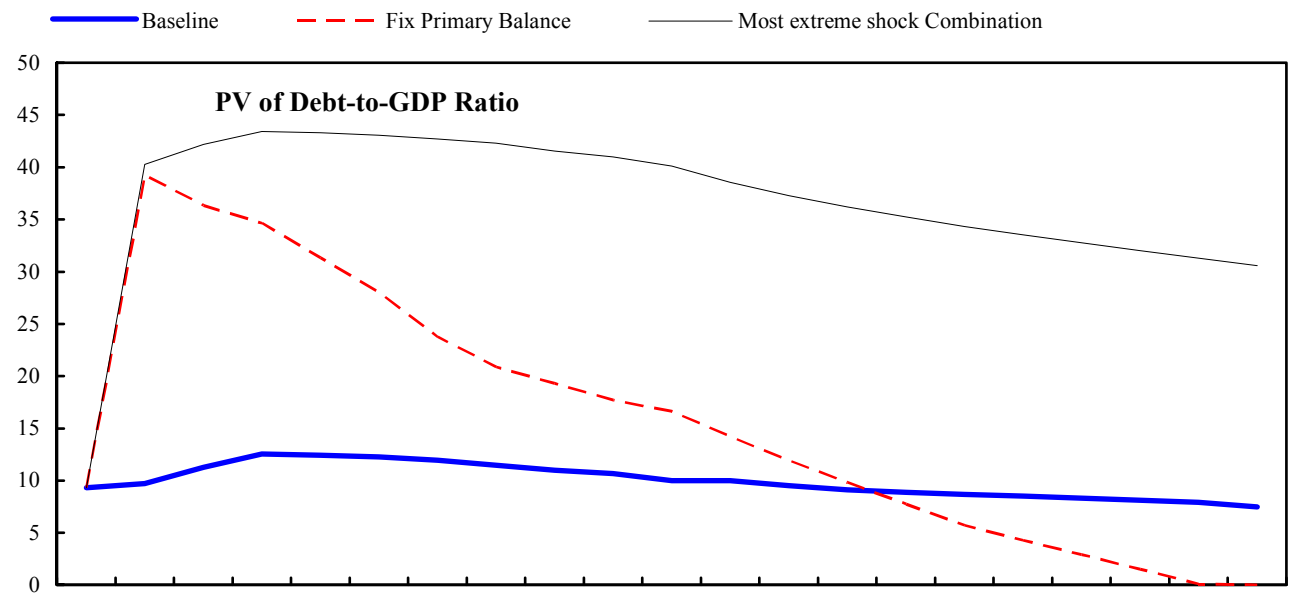

200820092010201120122013201420152016201720182019202020212022202320242025202620272028

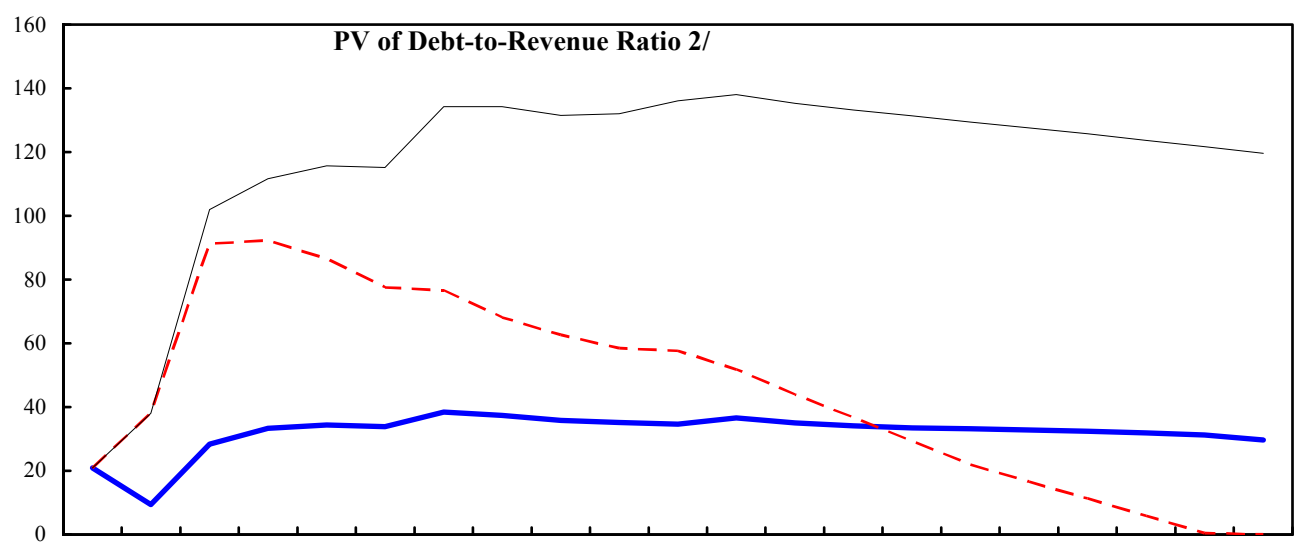

200820092010201120122013201420152016201720182019202020212022202320242025202620272028

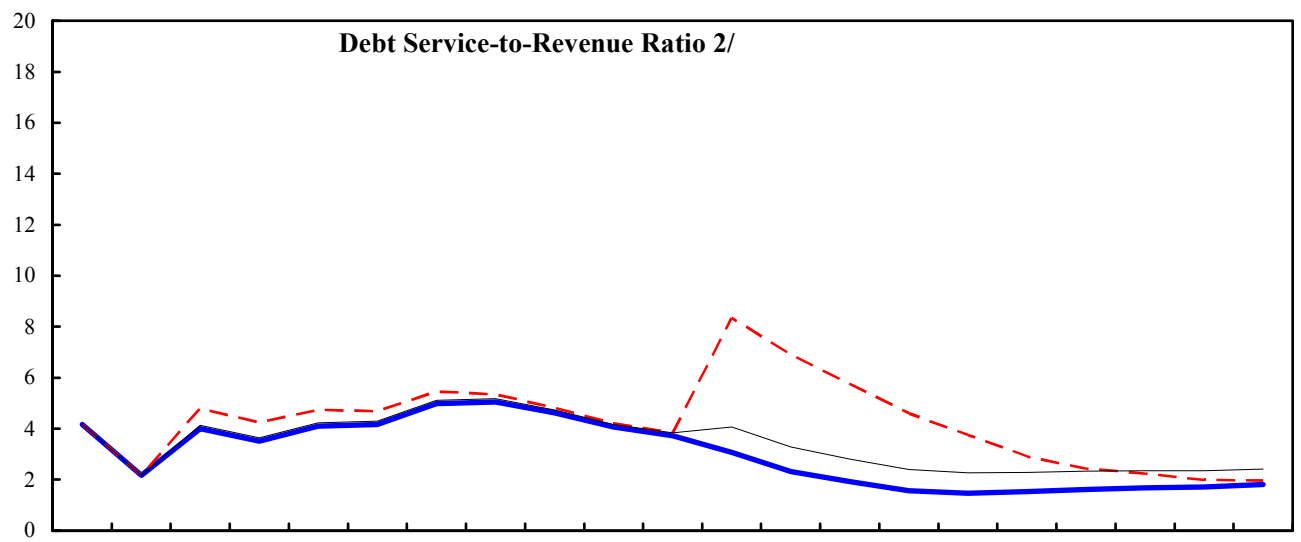

200820092010201120122013201420152016201720182019202020212022202320242025202620272028

Sources: Country authorities; and Fund staff estimates and projections.

1/ The most extreme stress test is the test that yields the highest ratio in 2018.

$2 /$ Revenues are defined inclusive of grants. 